PontifícIa Universidade CATÓlica do RIO dE JANEIRO

\title{
Propagando Emoções: um estudo sobre o efeito da utilização de emoções na divulgação de produtos.
}

Paulo Sérgio Miranda de Andrade

Trabalho de Conclusão de Curso

Centro de clências socials - CCS

DePARTAMENTO de AdMINISTRAÇÃo

Graduação em Administração de Empresas 
Paulo Sérgio Miranda de Andrade

Propagando Emoções: um estudo sobre o efeito da utilização de emoções na divulgação de produtos.

Trabalho de Conclusão de Curso, apresentado ao programa de graduação em Administração da PUC-Rio como requisito parcial para a obtenção do titulo de graduação em Administração.

Orientador: Barbara Levy

Rio de Janeiro, Julho de 2017. 
Aqui se fecha mais um ciclo em minha vida e se realiza um sonho. Um ciclo de grande aprendizado e amadurecimento que se finaliza com certeza do caminho que tenho para percorrer. Agradeço minha mãe por todo empenho para que eu adquira o melhor ensino e ao meu pai por acreditar cegamente em meu potencial. A todos professores e profissionais que me transferiram conhecimento para que esse projeto ganhasse vida. Aos meus amigos que me fizeram rir e relaxar quando precisei. Ao meu leal companheiro Everton por todo suporte, amor e carinho depositado em mim em conjunto com nossas filhas Sookie e Tituba. Agradeço a minha orientadora Barbara Levy pela generosidade, aprendizado e sugestões para que esse esse projeto chegue ao fim em sua melhor forma. 


\section{Resumo}

Andrade, Paulo Sérgio Miranda. Levy, Barbara. Propagando Emoções: um estudo sobre o efeito da utilização de emoções na divulgação de produtos. Rio de Janeiro, 2017. Número de páginas p. Trabalho de Conclusão de Curso - Departamento de Administração. Pontifícia Universidade Católica do Rio de Janeiro.

Este trabalho tem como principal objetivo analisar o efeito na decisão de compra dos consumidores quando utilizadas propagandas desenvolvidas utilizando teorias do design emocional.

Para aprofundar a análise, este trabalho fez uso do mercado de cosméticos e ensino, com enfoque em um shampoo e uma universidade trabalhados sem uma marca atrelada, procurando entender qual o efeito da propaganda que busque despertar uma emoção na decisão de compra sem impacto da marca.

Palavras- chave

Comportamento do Consumidor, Propaganda, Design Emocional, Decisão de Compra. 


\section{Abstract}

Andrade, Paulo Sérgio Miranda. Levy, Barbara. Propagando Emoções: um estudo sobre o efeito da utilização de emoções na divulgação de produtos. Rio de Janeiro, 2017. Número de páginas p. Trabalho de Conclusão de Curso - Departamento de Administração. Pontifícia Universidade Católica do Rio de Janeiro.

The main goal of this paper is to analyze the effects on the buying decision process of consumers when using advertisings developed using theories of emotional design.

For further analysis, this work made use of the cosmetics and teaching market, focusing on shampoo and university and making no use of brands attached to them so it can be possible to understand the effect made in the buying decision process of an advertising who seeks to elicit an emotion without the brand impact.

Key-words

Consumer Behavior, Advertisement, Emotional Design, Buying Decision Process. 


\section{Sumário}

1. O problema

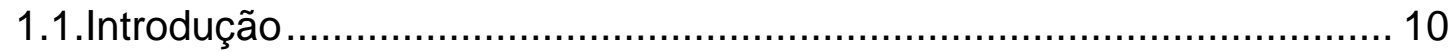

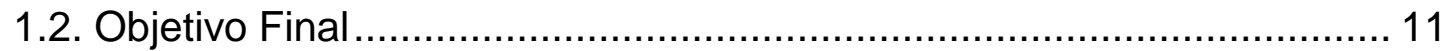

1.3. Objetivos Intermediários .................................................................. 11

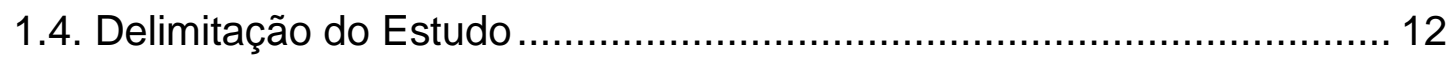

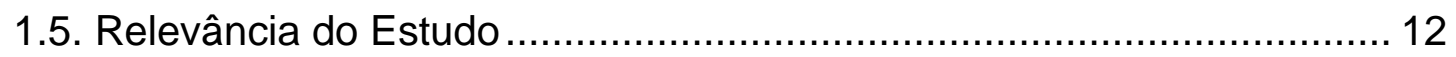

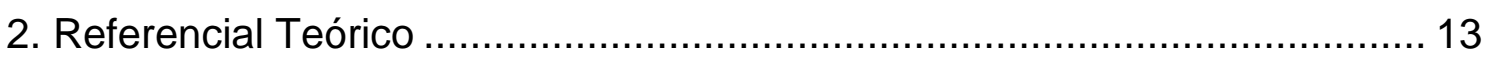

2.1. O processo de decisão de compra ................................................... 13

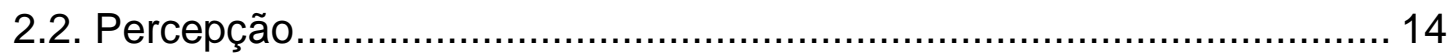

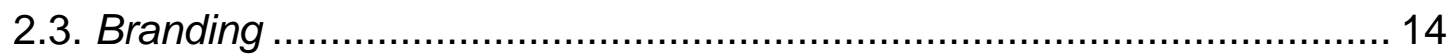

2.4. Processo de desenvolvimento de propaganda .................................. 15

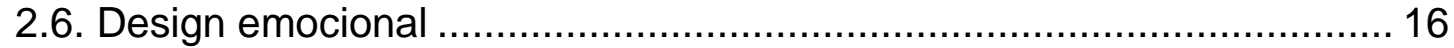

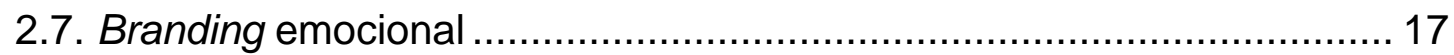

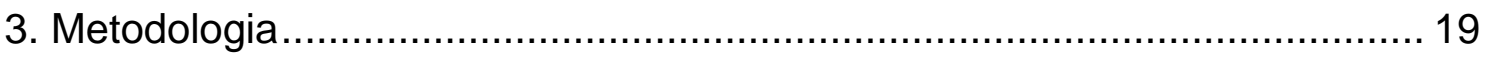

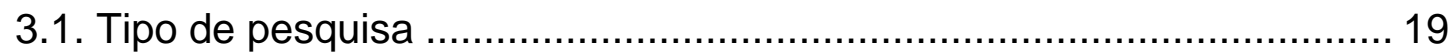

3.2. Primeira Fase - Pesquisa Qualitativa ................................................ 19

3.2.1. Coleta de dados - Fase Qualitativa ............................................. 19

3.2.2. Tratamento de dados - Fase Qualitativa ....................................... 20

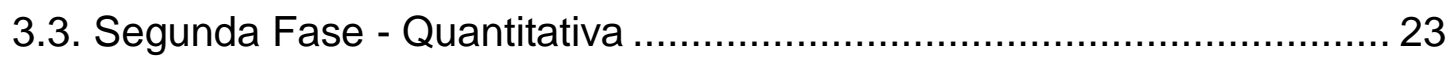

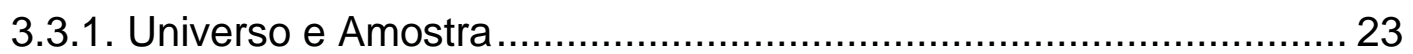

3.3.2. Coleta de Dados - Fase Quantitativa............................................ 24

3.3.3 Tratamento de Dados - Fase Quantitativa..................................... 25

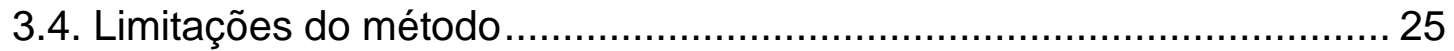

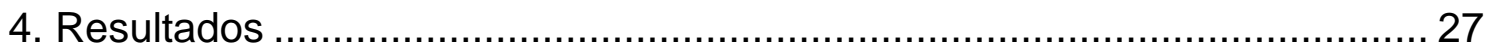

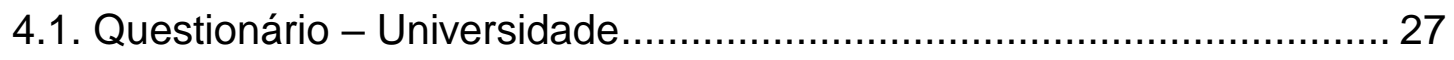

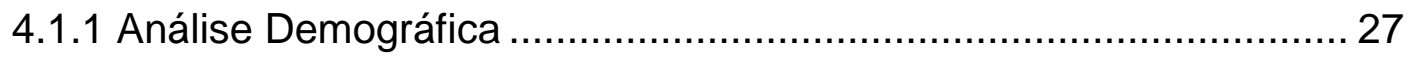




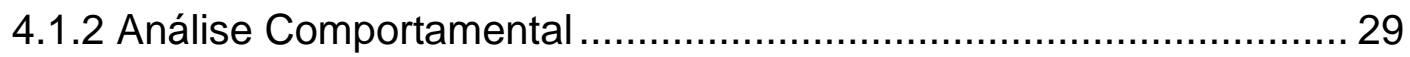

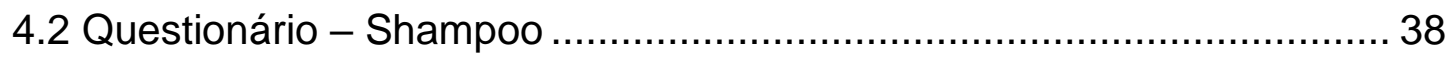

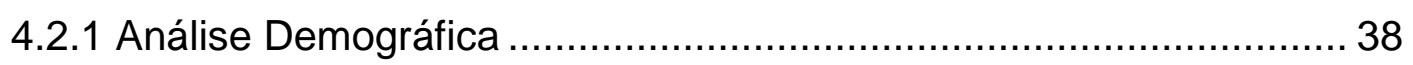

4.2.2 Análise Comportamental .......................................................... 40

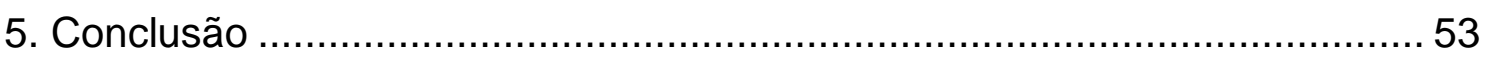

5.1 Sugestões e recomendações para novas pesquisas.............................. 54

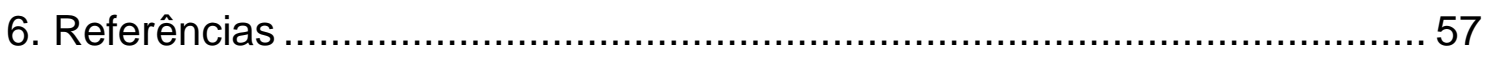

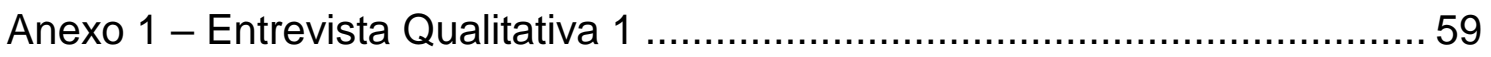

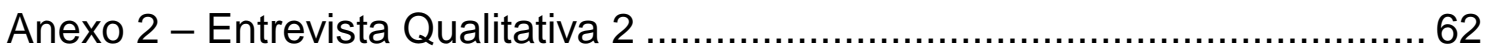

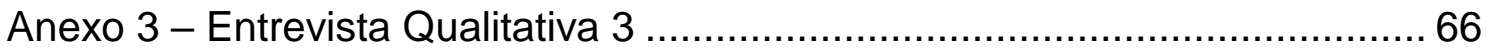

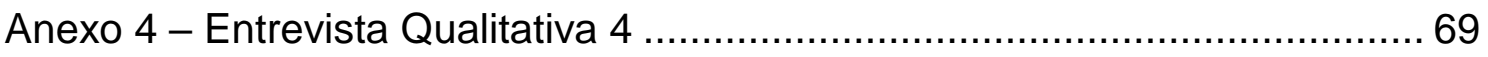

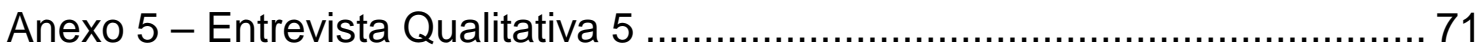

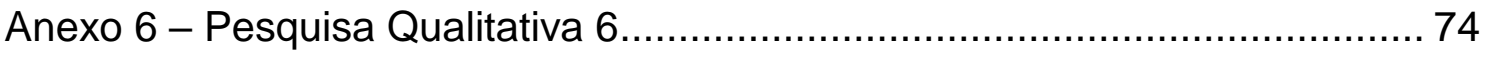

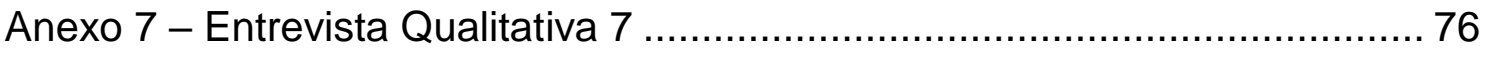

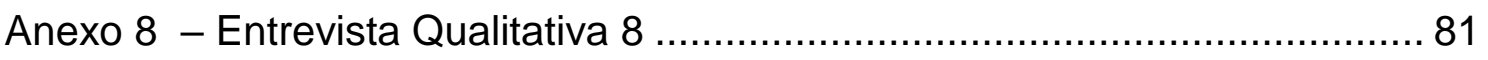

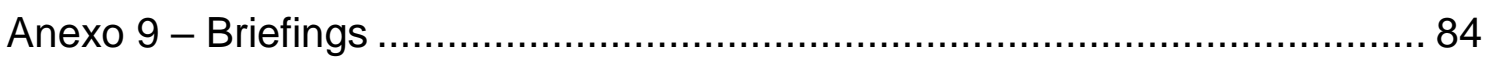

Anexo 10 - Questionário Quantitativo - Universidade ...................................... 87

Anexo 11 - Questionário Quantitativo - Shampoo ………………………..... 92

Anexo 12 - Propagandas Utilizadas na Pesquisa Quantitativa ......................... 97

\section{Lista de Figuras}

FIGURA 1 - ESTÁGIOS NA TOMADA DE DECISÃO DO CONSUMIDOR (FONTE: SOLOMON, 2011)

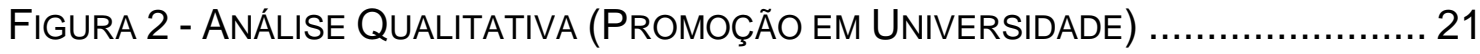

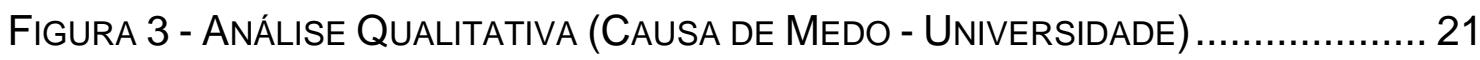

FIGURA 4 - ANÁLISE QUaLITATIVA (CAUSA DE FELICIDADE - UNIVERSIDADE) ............. 22

FIGURA 5 -ANÁLISE QUALITATIVA (CAUSA DE INVEJA - UNIVERSIDADE) .................. 22

Figura 6 - Análise Qualitativa - Causa de Medo (Shampoo) ........................... 23 
Figura 7 - Análise Qualitativa - Causa de Felicidade (Shampoo)................... 23

FIGURA 8 - ANÁLISE QualiTATIVA - CAUSA DE INVEJA (SHAMPOO).......................... 23

FIGURA 9 - SUGESTÃo: PROCESSO DESIGN EMOCIONAL..................................... 55

\section{Lista de Tabelas}

TABELA 1 - DivisÃo POR CLASSE SoCIAL (UNIVERSIDADE) .................................. 29

TABELA 2 - FATORES DE INFLUÊNCIA (UNIVERSIDADE) …….............................. 30

TABELA 3 - ANÁLISE ESCALA DE LIKERT (UNIVERSIDADE) …................................ 38

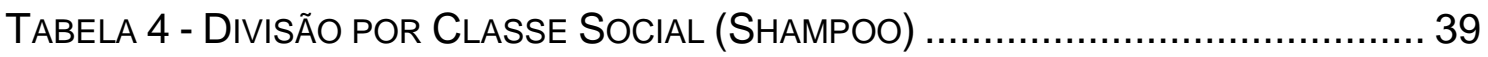

TABELA 5 - FATORES DE INFLUÊNCIA (SHAMPOO) ................................................ 42

TABELA 6 - ANÁLISE ESCALA DE LIKERT (SHAMPOO) ......................................... 52

\section{Tabela de Gráficos}

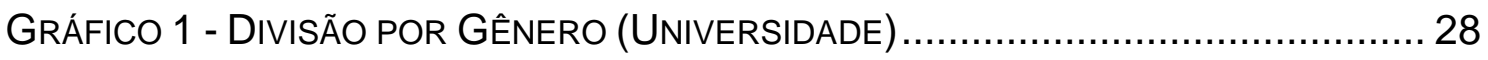

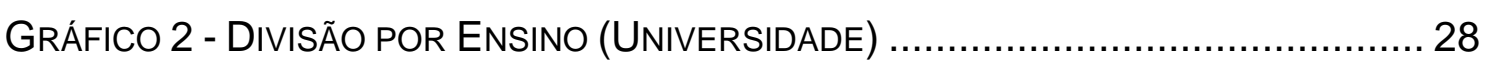

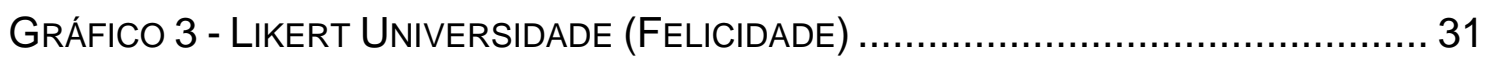

GRÁFICO 4 - ESCALA DE SENSAÇÕES (UNIVERSIDADE - FELICIDADE) ....................... 31

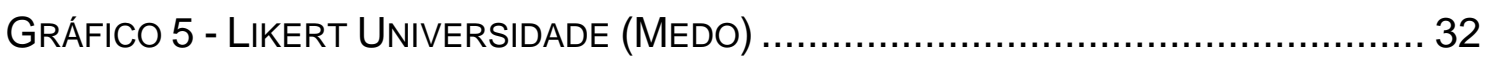

GráfICO 6 - EsCALA de SeNSAÇÕES (UNIVERSIDADE - MEDO) ……....................... 32

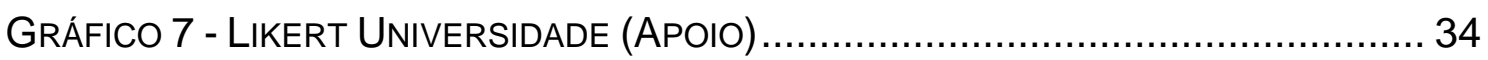

GRÁFICO 8 - ESCALA DE SENSAÇÕES (UNIVERSIDADE - APOIO) ……….................... 35

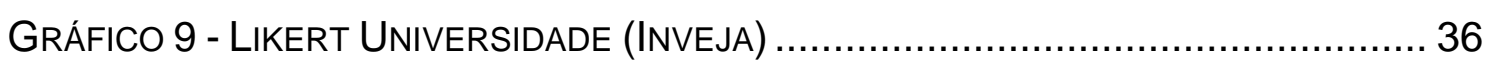

GRÁFICO 10 - ESCALA DE SENSAÇÕES (UNIVERSIDADE - INVEJA) ........................... 37

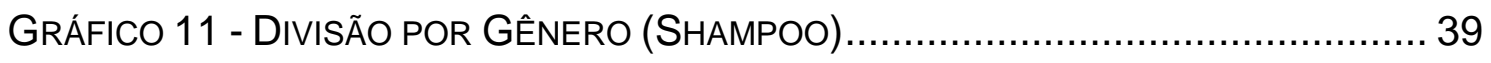

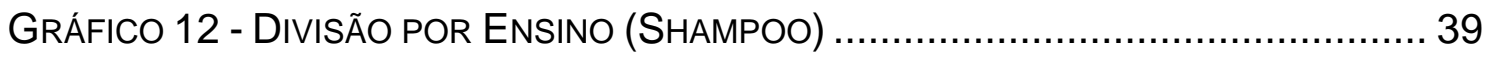

GRÁFICO 13 - DECISÃO DE COMPRA (SHAMPOO) ……..................................... 41

GRÁFICO 14 - LIKERT SHAMPOO (FELICIDADE) ……...................................... 42

GráfICO 15 - Escala de SENSAÇÕES (SHAMPOO - FelicidadE) ........................... 43

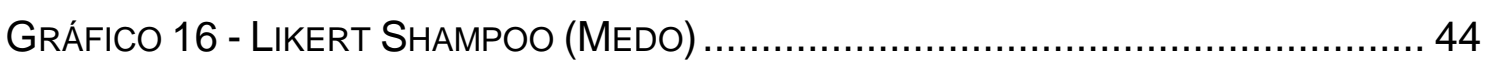

GráfICO 17 - Escala de SENSAÇÕES (SHAMPOO - Medo) …................................46

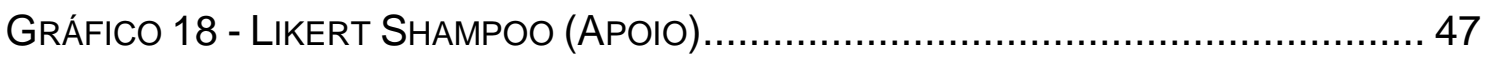

GráFICO 19 - ESCALA dE SENSAÇÕES (SHAMPOO - APOIO)................................. 48 
GRÁFICO 20 - LIKERT SHAMPOO (INVEJA). 50

GráFICO 21 - ESCALA DE SENSAÇÕES (ShamPOO - INVEJA) ................................. 51 


\section{O problema}

\subsection{Introdução}

Entender os processos que envolvem a compra de um produto, iniciando nas necessidades do consumidor a serem supridas, é um dos objetivos de gestores e pesquisadores interessados no comportamento do consumidor. Mercados são segmentados, mensurados e produtos são ofertados através de uma comunicação adequada ao público alvo, levando em consideração fatores tanto demográficos como psicográficos. (CHURCHILL \& PETER, 2010).

Como forma de conseguir fatias de mercado maiores, as empresas já se mostram flexíveis a estratégias de marketing centradas no consumidor, colocando-o como centro de pesquisas (Design Thinking e Neuromarketing) ou proporcionando experiências sensoriais (Marketing Sensorial).

Uma área que tem se mostrado crescente no estudo do consumidor e, mais especificamente, no efeito da emoção sobre o consumidor, é o design. Os profissionais dessa área possuem uma vertente chamada design emocional, que busca entender a psicologia por trás das emoções e desenvolver ferramentas que consigam mensurar o grau em que tais emoções são despertadas no consumidor ao interagir com certo produto. $O$ design emocional permite a criação de insumos que otimizam o processo de projeção dos produtos, inserindo nele a capacidade de criação de produtos, que despertem emoções específicas. Os estudos na área acontecem de diversas formas, sendo eles focados em emoções específicas (LU, 2012) ou abrangendo experiências complexas que abraçam diversas emoções, como o amor (RUSSO, 2010).

Diversos estudos em diferentes áreas da medicina buscam há anos entender o processo biológico e consequências que as emoções podem causar no ser humano. A emoção possui diversas teorias separadas, levando em consideração a cognição, nível de complexidade e duração da mesma, sem que uma única dessas teorias seja capaz de definir aceitavelmente os efeitos gerais da emoção. Emoções são estudadas dentro da psicologia, psiquiatria e neurologia, possuindo estudos até na neurociência, que busca entender os mecanismos neurais da emoção. 
A partir do olhar da área de Administração de Empresas, é possível identificar facilmente o uso de emoções em propagandas de grandes marcas, o que demonstra a preocupação dos profissionais de marketing com o uso estratégico de emoções. Existem vertentes dentro do marketing que levam em consideração as emoções, como o branding emocional, que formula estratégias de comunicação que construam marcas em conjunto com emoções.

Visto que as estratégias de comunicação que atingem os consumidores, em sua maioria, são trabalhadas em conjunto com uma marca que influencia o valor do produto/serviço, o valor exato da influência da emoção em uma estratégia de comunicação permanece pouco entendida. Visando entender melhor essa relação, a pergunta que o presente trabalho busca responder é: Como determinadas emoções estimuladas na comunicação de alguns produtos afetam a decisão de compra de certos produtos?

\subsection{Objetivo Final}

O objetivo final do presente trabalho consiste em identificar variações na intenção de compra ocasionadas por emoções estimuladas na divulgação de determinados produtos.

\subsection{Objetivos Intermediários}

Com a finalidade de atingir o objetivo final deste trabalho, ao longo do seu desenvolvimento serão buscados os seguintes objetivos:

- Identificar relações feitas por consumidores, entre as emoções e produtos previamente selecionados.

- Identificar diferenças nos efeitos das emoções específicas sobre a decisão de compra, quando trabalhadas na divulgação de produtos distintos.

- Avaliar que emoção possui maior alteração sobre a decisão de compra de cada produto trabalhado.

- Identificar possíveis alterações na decisão de compra ao utilizar comunicação que intencione despertar emoções específicas. 


\subsection{Delimitação do Estudo}

Para o presente estudo, o termo "divulgação" foi limitado por comunicações em mídias impressas e será direcionado para situações de consumo por indivíduos (B2C - Business to Consumer). Os produtos/serviços escolhidos como objeto de estudo são: shampoo e universidade, representando um produto e um serviço.

O estudo foi feito utilizando-se três emoções específicas, levantadas na primeira etapa (qualitativa) desse estudo, sendo seus resultados limitados às alterações geradas por elas. As emoções trabalhadas foram: medo, felicidade e inveja. Tais emoções foram escolhidas por serem mais fáceis de serem utilizadas e percebidas em uma divulgação de produto.

O contexto está limitado ao Brasil e a pesquisa foi realizada no primeiro semestre de 2017.

\subsection{Relevância do Estudo}

O trabalho é relevante para estudiosos de marketing, visto que o assunto possui poucos estudos focados até o presente momento. Assim, ele serve de incentivo para futuros estudos e apresenta análises sobre a possível relevância de emoções, complementando estudos de estratégias já existentes, como o emotional branding, e trazendo insumos para estudos na área de comportamento do consumidor.

Também é importante para publicitários e profissionais de marketing que utilizem mídia impressa, trazendo para eles um conhecimento da influência que as emoções específicas trabalhadas podem causar em suas peças de propaganda, para que possuam mais conteúdo em seu trabalho.

É relevante também para designers de produtos, visto que acrescentará análises que ligam o fenômeno de emotional branding à criação de peças publicitárias, complementando assim seus estudos de emoções inseridas em um produto/serviço. 


\section{Referencial Teórico}

\subsection{O processo de decisão de compra}

O processo de decisão de compra pode ser descrito por uma sequência composta por quatro passos, sendo eles: reconhecimento do problema, busca de informações, avaliação de alternativas e escolha do produto. A avaliação do consumidor quanto à decisão final tomada vai trazer aprendizado (positivo ou negativo) para futuros processos de decisão. (SOLOMON, 2011).

\section{Reconhecimento do problema}

\section{Busca de Informações}

\section{Avaliação de Alternativas}

\section{Escolha do Produto}

Figura 1 - Estágios na tomada de decisão do consumidor (Fonte: SOLOMON, 2011)

O primeiro passo do processo, chamado de reconhecimento do problema, consiste no momento em que o consumidor observa uma necessidade a ser suprida. Exemplificando, o consumidor que está com fome (necessidade) reconhece que tem um problema (precisa se alimentar).

Após o reconhecimento do problema, o consumidor segue então para a busca de informações. Seguindo o exemplo, o consumidor, após sentir fome, procura formas de saciá-la, buscando informações sobre as opções de alimentação. 
Então no terceiro passo do processo ele realiza uma avaliação das alternativas: ele pode comer em uma lanchonete ou decidir cozinhar em casa, por exemplo.

Por fim, o consumidor escolhe qual produto irá comprar e avalia se sua escolha foi correta, guardando a experiência do produto na memória, para que ela seja utilizada em um processo de decisão futuro.

\subsection{Percepção}

A percepção consiste em um processo no qual selecionamos, organizamos e interpretamos os estímulos que recebemos (SOLOMON, 2011).

Inicialmente recebemos estímulos e quando são colocados em um ambiente relevante e chegam ao alcance dos nervos sensoriais de percepção (olhos, ouvidos, nariz, boca, pele), pode-se dizer que estamos expostos a eles. Um fator importante nesse estágio é o limiar absoluto, que consiste no mínimo estímulo necessário para ser detectado pelos sentidos. Já o limiar sensorial consiste em reconhecer diferenças entre dois ou mais estímulos, causando, assim, um diferencial.

No segundo passo do processo temos a atenção, que consiste no momento em que as sensações resultantes dos estímulos são processadas no cérebro. Exemplificando, passamos todos os dias por diversas propagandas na rua, mas poucas são gravadas em nosso cérebro e lembramos posteriormente.

Por fim, temos o estágio de interpretação, quando significados são atribuídos às sensações. Tais significados são conferidos por meio de esquemas chamados de modelos mentais de comportamento.

\subsection{Branding}

Como forma de poder se diferenciar e se fixar na mente dos consumidores junto a atributos específicos, é preciso que o produto/serviço possua algo que reflita tudo o que se deseja transmitir. Para essa função, existe o branding, que consiste na criação de uma marca atrelada ao produto/serviço para que, através 
dela, se consiga passar aos clientes todos os valores desejados. Dessa forma, ao ouvir ou pensar na marca, o consumidor consegue resgatar de sua memória as características do produto e até mesmo as vantagens e desvantagens que ele tem perante seus concorrentes. $O$ branding, quando bem utilizado, consegue diferenciar um produto e posicioná-lo adequadamente na comparação com os restantes em sua categoria. (KOTLER; KELLER, 2006).

Conseguimos, por exemplo, apenas de ouvir/ver a marca "Coca Cola", relacioná-la a um refrigerante líder de mercado ou, por conta de duas famosas propagandas, à felicidade, momentos em família e Natal. Assim, ela se posiciona de modo diferente de sua principal concorrente, a Pepsi, que tem o posicionamento focado em propagandas que despertam o espírito jovem.

Além de trazer a característica de diferenciação no mercado, uma marca possui valor patrimonial, sendo ele um conjunto de ativos tangíveis e intangíveis chamado de brand equity. As marcas então, além de remeter a símbolos, cores ou música, também possuem personalidade, que é definida pelas características humanas atreladas à marca. (AAKER, 2011).

\subsection{Processo de desenvolvimento de propaganda}

O processo de desenvolvimento de uma propaganda se inicia no briefing elaborado pela área de marketing, que define como gostaria de se comunicar com seu consumidor. Cabe à agência de publicidade desenvolver uma propaganda que consiga passar ao consumidor o objetivo estratégico desenvolvido pelo marketing, utilizando de criações empáticas e criativas, como forma de se destacar perante o mercado.

Para que as propagandas atinjam um diferencial, é papel da equipe de criação da agência (ou área de Comunicação) traduzir o objetivo de marketing em algo além, mostrando benefício ao cliente de forma despretensiosa, nada coloquial e, se possível, despertando um desejo pelo cenário ou produto apresentado na propaganda. (VIEIRA, 2007).

A criação de uma peça publicitária deve equilibrar os interesses comerciais de um cliente (empresa que contrata a agência), a expressão artística do publicitário e os desejos dos consumidores. Dessa forma, o desenvolvimento 
será inteiramente guiado pelos desejos e respostas do consumidor, levando em consideração os objetivos comerciais e insights de mercado trazidos pelo cliente, com respeito à força da arte e valorização do profissional, trazendo-o para o processo de forma consciente. (STEEL, 2006).

\subsection{Design emocional}

Emoções são experiências individuais que resultam em alterações fisiológicas e respostas comportamentais. Diferenciando as respostas comportamentais geradas pelas emoções entre animais e seres humanos, por conta da evolução nas estruturas corticais e conexão diversificada com o sistema límbico, os humanos são capazes de respostas comportamentais diversas frente às emoções, enquanto animais possuem respostas padronizadas (GUYTON, 1985). Em geral, emoções positivas tendem a gerar repetições e emoções negativas tendem à eliminação. (PAVLOV, 1960).

Segundo Demir et a.I (2009, apud TONETTO, L.; COSTA, 2001), o design emocional consiste em uma área onde se projetam produtos com o intuito explícito de despertar ou evitar determinadas emoções. Segundo eles, os três autores com maior relevância no assunto são Patrick Jordan, Pieter Desmet e Donald Norman.

Jordan (1999) explicitou em seu estudo que a ligação do consumidor com o produto adquirido ou usado resulta em uma obtenção de prazer. O produto poderia fornecer quatro tipos de prazeres e seria possível entendê-los como forma de melhorar a projeção de produtos. Seriam eles: fisiológico, relacionado ao estímulo sensorial produzido pelo produto; social, produzido pela interação das pessoas que cercam o usuário; psicológico, advindo dos prazeres mentais gerados pelo produto, como uma usabilidade melhor que a esperada; e ideológico, proveniente da relação entre a construção ideológica do consumidor e o produto, exemplificado pelo prazer obtido ao consumir um produto sustentável.

Desmet (2002) apresentou um modelo componencial no qual é possível avaliar o significado de um estímulo produzido por um produto, classificando-o como contribuidor (aquele que origina emoções positivas) ou ameaçador (aquele 
que origina emoções negativas), entendendo como o produto e os interesses do consumidor produzem uma avaliação que origina a emoção e permite que se projete com o intuito de despertar emoções específicas.

Ao projetar produtos, podem ser usados quatro focos: no usuário, entendendo a emoção por seu ponto de vista; no designer, que buscaria design desafiador como forma de despertar emoções; em pesquisa, em que pesquisas são utilizadas como insumos; na teoria, quando teorias fornecem ferramentas que ajudam o designer a medir o grau de emoção que seu design evoca.

Norman (2004) trouxe para a área um modelo que relaciona as emoções em três níveis de processamento cerebral: visceral, que abrange a reação automática do ser humano frente aos estímulos da natureza; comportamental, sendo o nível relacionado à usabilidade do produto; e reflexivo, nível em que se inserem os significados do produto para o usuário. Cada nível de processamento traz oportunidades de enriquecer a projeção de produtos.

\subsection{Branding emocional}

Apesar do mundo dos negócios estar norteado por pesquisas, previsões de tendências, estratégias e avaliação de marcas, o consumidor pensa de outra forma. Ele é cercado por desejos subconscientes, aspirações emocionais, estímulos de design, instinto visceral (primeira impressão) e explorações sensoriais. Dessa forma, é possível observar o contraste entre o mundo dos negócios, focado na razão, e o mundo do consumidor, focado na emoção.

No branding emocional, o consumidor é colocado como regra, utilizandose de um marketing um para um, diferente da atual utilização do branding com criações voltadas para números e padrões observados. A necessidade de um marketing um para um se junta à característica do design de fornecer experiências viscerais, intuitivas e que mexem com o subconsciente do consumidor.

A criação de estratégias de branding é feita de forma colaborativa entre mercado, designer e executivo, utilizando de ferramentas para criar uma identidade emocional e uma personalidade da marca antes de seguir desenvolvendo uma estratégia de branding a ser posta em diversas plataformas. 
Tal vertente proporciona entender diferentes apropriações que pessoas diversas fazem das marcas, levando a soluções para empresas que desejam manter uma marca sempre alinhada ao consumidor, mesmo que internacionalizada, pois considera o consumidor local em suas aplicações. (GOBÉ, 2010).

Algumas empresas já se utilizam de emoções na construção de suas marcas e obtêm resultados positivos, levando o branding emocional para a área de pesquisas. (ROSSITER, J.; BELLMAN, S, 2012). 


\section{Metodologia}

\subsection{Tipo de pesquisa}

O presente trabalho, quanto aos fins, possui o tipo de pesquisa descritiva, visto que busca estabelecer correlações entre variáveis e definir sua natureza.

Quanto aos meios de investigação, foram utilizados pesquisa de campo e pesquisa experimental, com aplicação de questionários e manipulação de variáveis independentes como forma de observar as alterações ocorridas. (VERGARA, 2004)

A pesquisa foi composta de duas fases, sendo uma qualitativa e a outra quantitativa. A pesquisa qualitativa foi realizada com o objetivo de, além de buscar insumos de como os mercados escolhidos se divulgam, identificar relações feitas por consumidores, entre as emoções e produtos previamente selecionados, para que fossem consideradas na criação das mídias.

Com as mídias desenvolvidas, a pesquisa entrou em sua segunda fase, a quantitativa. A segunda fase buscou diferenças nos efeitos das emoções específicas sobre a decisão de compra, quando trabalhadas na divulgação de produtos distintos. Outro objetivo foi avaliar que emoção possui maior alteração sobre a decisão de compra de cada produto trabalhado.

\subsection{Primeira Fase - Pesquisa Qualitativa}

\subsubsection{Coleta de dados - Fase Qualitativa}

Na primeira fase, foi realizada uma pesquisa qualtitativa exploratória, realizando entrevistas semiestruturadas com oito respondentes, visando buscar insumos das emoções trabalhadas, para que fossem elaboradas as propagandas a serem testadas.

Para que os insumos trazidos pelos entrevistados pudessem simular opiniões mais gerais do público, foram selecionados para essas entrevistas: profissionais dos setores trabalhados, inseridos em áreas de contato com peças publicitárias (transcritas nos anexos 2 e 7); três usuários de shampoo 
(um jovem adulto de cada sexo e um adulto mais maduro - transcritas nos anexos 5, 6 e 8); três usuários de universidade (um de ensino particular, um de ensino público e um profissional acadêmico - transcritas nos anexos 1, 3 e 4).

As entrevistas buscaram entender dois pontos: como as marcas trabalhadas divulgam seus produtos e como os respondentes pensam sobre as emoções trabalhadas. Essa fase buscou insumos seguindo a teoria de Desmet (2002), que aponta a necessidade de projeção dos produtos a partir do usuário.

Após analisadas as entrevistas, um briefing foi elaborado com suporte de um profissional de Comunicação. O material foi entregue a um designer e os anúncios impressos foram criados com o propósito de projetar medo, felicidade e inveja - emoções selecionadas com base nas análises das entrevistas obtidas nessa fase qualitativa. Essas peças publicitárias foram usadas nos questionários aplicados na segunda fase do estudo.

Foram excluídos do estudo quaisquer marcas possíveis, como forma de eliminar o fator marca e suas variáveis do estudo.

\subsubsection{Tratamento de dados - Fase Qualitativa}

Os dados das entrevistas foram tratados inspirados na análise de conteúdo, visando entender que atributos foram ligados a cada emoção, sob o ponto de vista do entrevistado, como forma de trazer insumos para a projeção de emoções, conforme indica Desmet (2002).

Foi escolhida uma análise fechada (VERGARA, 2004), utilizando as seguintes categorias para ambos produtos: promoção de produtos, causas de medo, causas de felicidade, causas de inveja. As unidades utilizadas para formar os elementos foram: palavra e expressão.

$\mathrm{Na}$ análise feita referente as entrevistas sobre universidade, os elementos que preenchem as categorias são descritos e mostrados nas tabelas a seguir. As entrevistas aparecem classificadas como E1 para Entrevista 1 e assim adiante.

Para a análise da Promoção da Universidade, foram consideradas na categoria cartazes, citações de outdoor, busdoor e folhetos. No entanto, 
como é possível ver na Figura 2, há um maior uso de mídia online na divulgação de universidades.

\begin{tabular}{|c|c|c|c|c|}
\hline \multirow{2}{*}{} & \multicolumn{4}{|c|}{ Promoção (Universidade) } \\
\cline { 2 - 5 } & $\mathrm{E} 1$ & $\mathrm{E} 2$ & $\mathrm{E} 3$ & $\mathrm{E} 4$ \\
\hline Rádio & $\mathrm{X}$ & & $\mathrm{X}$ & \\
\hline Cartazes & $\mathrm{X}$ & & $\mathrm{X}$ & \\
\hline Boca a Boca & $\mathrm{X}$ & & & \\
\hline Eventos & $\mathrm{X}$ & $\mathrm{X}$ & & \\
\hline Mídia Online & & $\mathrm{X}$ & $\mathrm{X}$ & $\mathrm{X}$ \\
\hline
\end{tabular}

Figura 2 - Análise Qualitativa (Promoção em Universidade)

Entrando no entendimento das emoções para os entrevistados, os seguintes resultados foram obtidos.

No entendimento das emoções para os entrevistados é possível concluir que, para os entrevistados, a causa de medo ligada a universidade mais relevante é o sentimento de estar escolhendo o curso e/ou a universidade errada. Também foram apontados como causas de felicidade ligada a universidade o sentimento de pertencer-se ao espaço, sentir-se bem no local e poder trocar experiência. Já, como causas de inveja, as causas relevantes foram a excelência da universidade e oportunidades oferecidas por ela. Para a categoria de Excelência da Universidade, foram consideradas citações de colocação da universidade; para a categoria Oportunidades, foram consideradas expressões ligadas ao investimento da universidade nos alunos.

\begin{tabular}{|l|c|c|c|c|}
\hline \multirow{2}{*}{} & \multicolumn{3}{|c|}{ Causa de Medo (Universidade) } \\
\cline { 2 - 5 } & $\mathrm{E} 1$ & $\mathrm{E} 2$ & $\mathrm{E} 3$ & $\mathrm{E} 4$ \\
\hline Escolher errado & $\mathrm{X}$ & $\mathrm{X}$ & $\mathrm{X}$ & \\
\hline Perder tempo & $\mathrm{X}$ & & & \\
\hline $\begin{array}{l}\text { Falta de } \\
\text { empregabilidade }\end{array}$ & $\mathrm{X}$ & & & \\
\hline Não ter retorno & $\mathrm{X}$ & & & \\
\hline Sentir-se perdido & & & & $\mathrm{X}$ \\
\hline
\end{tabular}

Figura 3 - Análise Qualitativa (Causa de Medo - Universidade)

\begin{tabular}{|c|c|c|c|c|}
\hline & \multicolumn{4}{|c|}{$\begin{array}{c}\text { Causa de Felicidade } \\
\text { (Universidade) }\end{array}$} \\
\cline { 2 - 5 } & $\mathrm{E} 1$ & E2 & E3 & E4 \\
\hline Pertencer ao espaço & $\mathrm{X}$ & $\mathrm{X}$ & & \\
\hline
\end{tabular}




\begin{tabular}{|c|c|c|c|c|} 
Sentir-se bem no local & $\mathrm{X}$ & & $\mathrm{X}$ & \\
\hline Fazer o que gosta & $\mathrm{X}$ & & & \\
\hline Estar com amigos & $\mathrm{X}$ & & & \\
\hline Trocar experiência & & $\mathrm{x}$ & $\mathrm{x}$ & \\
\hline Ter uma chance & & & $\mathrm{X}$ & \\
\hline $\begin{array}{c}\text { Reconhecimento da } \\
\text { universidade }\end{array}$ & & & & $\mathrm{X}$ \\
\hline Investimento no aluno & & & & $\mathrm{X}$ \\
\hline
\end{tabular}

Figura 4 - Análise Qualitativa (Causa de Felicidade - Universidade)

\begin{tabular}{|l|c|c|c|c|}
\hline \multirow{2}{*}{} & \multicolumn{4}{|c|}{ Causa de Inveja (Universidade) } \\
\cline { 2 - 5 } & $\mathrm{E} 1$ & $\mathrm{E} 2$ & $\mathrm{E} 3$ & $\mathrm{E} 4$ \\
\hline $\begin{array}{l}\text { Excelência da } \\
\text { universidade }\end{array}$ & $\mathrm{X}$ & $\mathrm{X}$ & $\mathrm{X}$ & \\
\hline Oportunidades & $\mathrm{X}$ & $\mathrm{X}$ & & $\mathrm{X}$ \\
\hline Segurança & $\mathrm{X}$ & & & \\
\hline Pessoas de referência & & $\mathrm{X}$ & & \\
\hline Retorno & & & & $\mathrm{X}$ \\
\hline
\end{tabular}

Figura 5-Análise Qualitativa (Causa de Inveja - Universidade)

$\mathrm{Na}$ análise feita com entrevistas focadas em shampoo, os insumos relacionados a divulgação do produto foram retirados apenas da entrevista 7 (anexo 7), pois pelo fato de a empresa da entrevistada realizar pesquisas e atuar no mercado nacional e internacional, assume-se que ela possa apresentar insumos de como o mercado trabalha a promoção.

Foram apontadas como formas de divulgação duas frentes: a online, onde é trabalhada a mídia digital (Facebook, Youtube, Instagram) e Google Adwords; e a offline, com propagandas posicionadas em metrô, uso de comerciais em TV e materiais nos pontos de venda.

Analisando os resultados relacionados às emoções, conclui-se que a emoção medo é associada ao cabelo estragado, sendo esse cabelo majoritariamente apontado como um cabelo seco. Vale destacar também, que para o entrevistado masculino, a característica apontada como negativa foi o aparecimento de caspa, sendo relevante esse dado na criação da peça de um shampoo masculino.

Quando analisados os dados relacionados ao sentimento de felicidade ligado ao shampoo, destaca-se a aparência de um cabelo brilhante com o uso do produto. O mesmo elemento foi destaque na causa de inveja. 
Com esses insumos, foram elaborados os briefings para criação de peças para universidade e shampoo, que podem ser consultados no anexo 9. As peças criadas pelo designer podem ser consultadas no anexo 12.

\begin{tabular}{|l|c|c|c|c|}
\hline & \multicolumn{4}{|c|}{ Causa de Medo (Shampoo) } \\
\cline { 2 - 5 } & E5 & E6 & E7 & E8 \\
\hline Estragar o cabelo & $\mathrm{X}$ & & $\mathrm{X}$ & \\
\hline Cabelo Seco & $\mathrm{X}$ & & $\mathrm{X}$ & \\
\hline Caspa & & $\mathrm{X}$ & & \\
\hline Cabelo cheio & & & $\mathrm{X}$ & \\
\hline Queda de cabelo & & & & $\mathrm{X}$ \\
\hline Teste em animais & & & & $\mathrm{X}$ \\
\hline
\end{tabular}

Figura 6 - Análise Qualitativa - Causa de Medo (Shampoo)

\begin{tabular}{|c|c|c|c|c|}
\hline & \multicolumn{4}{c|}{ Causa de Felicidade (Shampoo) } \\
\cline { 2 - 5 } & $\mathrm{E} 5$ & $\mathrm{E} 6$ & $\mathrm{E7}$ & $\mathrm{E} 8$ \\
\hline Cabelo brilhante & $\mathrm{X}$ & & & $\mathrm{X}$ \\
\hline Cabelo esvoaçante & $\mathrm{X}$ & & & \\
\hline Cabelo liso & & $\mathrm{X}$ & & \\
\hline Saber o resultado & & & $\mathrm{X}$ & \\
\hline $\begin{array}{c}\text { Sem teste em animais } \\
\text { Preço acessível }\end{array}$ & & & & $\mathrm{X}$ \\
\hline $\begin{array}{c}\text { Não deixar o cabelo } \\
\text { oleoso }\end{array}$ & & & & $\mathrm{X}$ \\
\hline Cabelo macio & & & & $\mathrm{X}$ \\
\hline
\end{tabular}

Figura 7 - Análise Qualitativa - Causa de Felicidade (Shampoo)

\begin{tabular}{|l|c|c|c|c|}
\hline \multirow{2}{*}{} & \multicolumn{4}{c|}{ Causa de Inveja (Shampoo) } \\
\cline { 2 - 5 } & $\mathrm{E} 5$ & $\mathrm{E} 6$ & $\mathrm{E} 7$ & $\mathrm{E} 8$ \\
\hline Cabelo brilhante & $\mathrm{X}$ & $\mathrm{X}$ & $\mathrm{X}$ & \\
\hline Corte do cabelo & $\mathrm{X}$ & & & \\
\hline Cabelo comprido & $\mathrm{X}$ & & & $\mathrm{X}$ \\
\hline Cabelo cheiroso & & $\mathrm{X}$ & $\mathrm{X}$ & \\
\hline Cor do cabelo & & & & $\mathrm{x}$ \\
\hline Cabelo macio & & & & $\mathrm{x}$ \\
\hline Sem química & & & & $\mathrm{x}$ \\
\hline
\end{tabular}

Figura 8 - Análise Qualitativa - Causa de Inveja (Shampoo)

\subsection{Segunda Fase - Quantitativa}

\subsubsection{Universo e Amostra}

O universo da pesquisa quantitativa consiste em consumidores de shampoo e universidade, além de possíveis consumidores de universidade. A amostra foi composta por 130 respondentes para 0 
questionário de universidade e 131 respondentes para o questionário de shampoo, sendo ambas não probabilística por acessibilidade.

\subsubsection{Coleta de Dados - Fase Quantitativa}

$\mathrm{Na}$ fase quantitativa, foram coletados dados por meio de dois questionários: um com perguntas voltadas para as propagandas de shampoo e outro voltado para as propagandas de universidade. Foram utilizadas perguntas fechadas e escala Likert.

O objetivo dessa fase era entender como as decisões de compra dos produtos trabalhados podem ser afetadas ao utilizar comunicação que intencione despertar emoções específicas, a validação de possíveis sensações despertadas pela mídia, além de perguntas relacionadas à classificação socioeconômica dos respondentes.

Como forma de identificar e medir as emoções a serem despertadas nas peças, foram utilizados nos questionários sinônimos das emoções trabalhadas retirados do dicionário de sinônimos. Para a emoção medo, foram utilizadas as sensações "angústia", "preocupação" e "aversão"; para a emoção felicidade, foram utilizadas as sensações "alegria", "prazer", "satisfação" e "contente"; para a emoção inveja, foram utilizadas as sensações "ciúme", "desejo", "cobiça" e "ambição". O questionário também buscou entender se as peças de apoio (criadas sem a intenção de despertar emoções) como forma de analisar se as peças utilizadas no mercado despertam algum tipo de emoção e possíveis alterações ao comparar a decisão de compra de ambos.

Foram considerados, para o questionário de shampoo, apenas usuários do produto, independente do sexo. Já para o questionário de universidade, foram considerados apenas respondentes que estejam buscando uma universidade ou estejam cursando no momento, como forma de buscar respondentes com uma relação próxima a escolha do serviço. Foram também excluídos respondentes que possuam escolaridade igual ou acima de mestrado incompleto. Os respondentes com escolaridade até graduação completa foram considerados, visto que eles possuem a oportunidade de trocar de universidade ou escolher um segundo curso para cursar, tornandoos possíveis consumidores do serviço. 
Além das mídias impressas que buscam despertar emoções, também foram utilizadas peças sem o intuito de despertar emoções, para serem utilizadas como grupo de controle (que podem ser consultadas no anexo). No total, foram utilizadas quatro mídias impressas por produto, variando assim a emoção trabalhada e utilizando uma peça de apoio já utilizada pelo mercado, omitindo somente a marca do produto para manter o afastamento do fator marca.

O questionário foi aplicado com um rodízio das mídias como forma de reduzir o efeito de ordem. Também foi realizado um rodízio das sensações que possam ser sentidas pelos respondentes pelo mesmo motivo.

O questionário de universidade teve seus dados coletados por questionário impresso, além do virtual na ferramenta Qualtrics, como forma de obter dados de estudantes de colégios e pré-vestibulares. Para garantir a redução do efeito de ordem citado na versão impressa, as páginas com as mídias foram grampeadas de forma aleatória e foram impressas versões que apresentavam a ordem das sensações de modo diferente.

Foi realizado um pré-teste com dez pessoas como forma de validar quaisquer ruídos que os questionários possam causar. Como não foram encontrados ruídos, o questionário então foi rodado.

\subsubsection{Tratamento de Dados - Fase Quantitativa}

Primeiramente foram analisados os dados socioeconômicos dos respondentes como forma de entender como a amostra está dividida frente a indicador de classe social, idade e sexo dos respondentes.

Em seguida, foi realizada uma análise da parte comportamental que a pesquisa visava entender. Seguindo a ordem das perguntas, buscou-se entender: quais os possíveis fatores de influência nos produtos trabalhados, como as propagandas influenciaram a decisão de compra de cada produto e se as mesmas obtiveram as sensações que validem as sensações desejadas.

\subsection{Limitações do método}

Algumas das principais limitações do método são: 
- Possibilidade de o respondente não ser parcial por ter ligação positiva ou negativa com uma das marcas trabalhadas.

- O respondente pode influenciar o resultado se não for um consumidor atual dos produtos trabalhados.

- Possível falta de acuracidade nas respostas por cansaço ou motivos pessoais.

- A quantidade limitada de respondentes da amostra na fase qualitativa pode afetar a abrangência de dados do universo trabalhado.

- Possíveis ruídos nas avaliações das peças publicitárias. Eles podem influenciar a leitura do respondente sobre as emoções que se intencionava transmitir. 


\section{Resultados}

Tal parte do presente trabalho busca entender quais as possíveis conclusões sobre os resultados obtidos na pesquisa realizada através dos questionários.

Como dito no tratamento de dados, a pesquisa foi realizada a partir das peças desenvolvidas a partir dos insumos obtidos na pesquisa qualitativa, utilizando de uma pesquisa de campo realizada por meio de dois questionários, um focado em usuários de shampoo e outro em usuários e possíveis consumidores de universidades.

\subsection{Questionário - Universidade}

\subsubsection{Análise Demográfica}

A análise do questionário foi descritiva, iniciando-se a partir do perfil dos respondentes, analisado nas perguntas de cunho demográfico (Questões 5, 6, 7 e 8 no Anexo 10).

Em relação ao gênero dos respondentes, houve uma porcentagem maior de pessoas sexo feminino (62,3\% da amostra) frente aos respondentes do sexo masculino (36,9\% da amostra). Quando analisamos a idade dos respondentes, a amostra obteve $69,2 \%$ de respostas de pessoas entre 16 e 20 anos, $23,8 \%$ de pessoas entre 21 e 25 anos e $6,9 \%$ de pessoas entre 26 e 35 anos. 


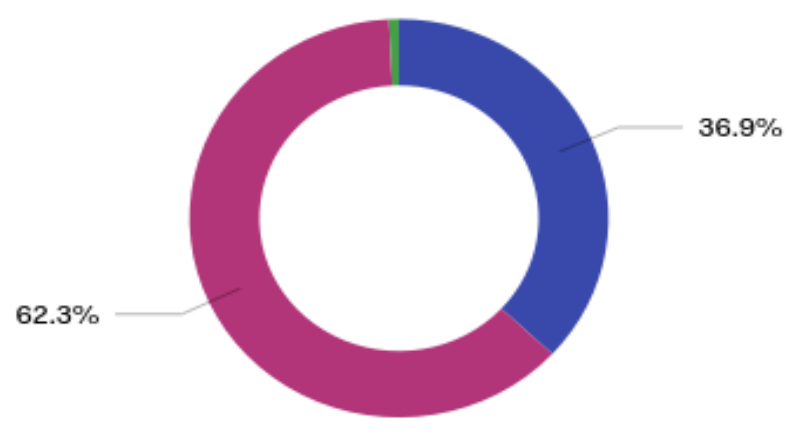

Masculino Feminino Outro

Como planejado, a amostra teve como grande representação pessoas com ensino médio incompleto, sendo elas mais da metade dos respondentes $(56,2 \%)$. Em seguida, a amostra é representada em sua maior parte por alunos de graduação incompleta $(26,2 \%)$ e alunos com ensino médio completo $(10,0 \%)$. Gráfico 2 - Divisão por Ensino (Universidade)

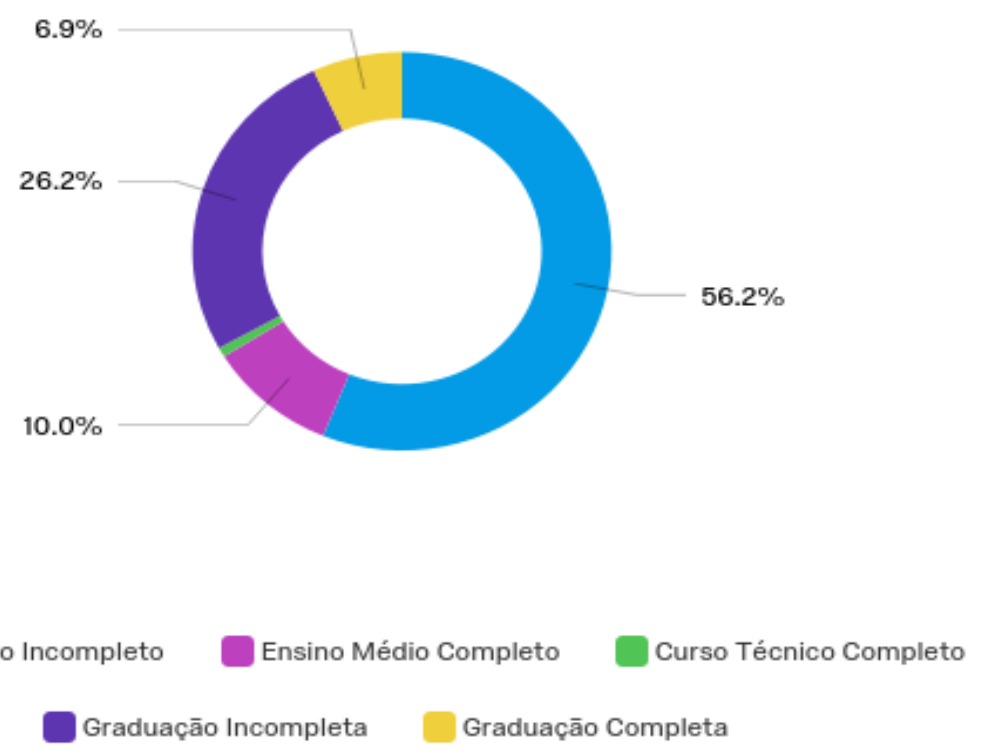

Utilizando como base o IBGE 2015, atualizando apenas o salário mínimo, foi possível obter a seguinte divisão de classes na amostra: $14,6 \%$ dos 
respondentes correspondem a classe $E, 18,4 \%$ correspondem à classe $D, 34,6 \%$ à classe $\mathrm{C}, 23,8 \%$ à classe $\mathrm{B}$ e $8,5 \%$ à classe $\mathrm{A}$.

Tabela 1 - Divisão por Classe Social (Universidade)

\begin{tabular}{|c|c|c|c|}
\hline \multicolumn{4}{|c|}{ Classe Social } \\
\hline Faixa Salarial $(\mathrm{R} \$)$ & Faixa Salarial (SM) & Classe Social & $\%$ da Amostra \\
\hline Até $\mathrm{R} \$ 1.874,00$ & Até 2 SM & Classe E & $14,6 \%$ \\
\hline Entre $\mathrm{R} \$ 1.874,01$ e $\mathrm{R} \$ 3.748,00$ & 2 a 4 SM & Classe D & $18,5 \%$ \\
\hline Entre $\mathrm{R} \$ 3.748,01$ e $\mathrm{R} \$ 9.370,00$ & 4 a $10 \mathrm{SM}$ & Classe C & $34,6 \%$ \\
\hline Entre $R \$ 9.370,01$ e $R \$ 18.740,00$ & 10 a 20 SM & Classe B & $23,8 \%$ \\
\hline $\mathrm{R} \$ 18.740,01$ ou mais. & Acima de 20 SM & Classe A & $8,5 \%$ \\
\hline
\end{tabular}

Legenda: SM = Salários Mínimos

\subsubsection{Análise Comportamental}

Visando entender o comportamento do consumidor frente ao serviço que era objeto de estudo, foram colocadas perguntas para entender qual fator influenciava mais o consumidor na escolha de uma universidade, qual propaganda provocava uma influência maior sobre a decisão de compra e quais sensações foram expostas como experenciadas ao observar as mídias.

Ao analisarmos a tabela 2, que traz os possíveis fatores de influência na escolha de uma universidade, pode-se observar que no geral o custo $(50,8 \%)$, o reconhecimento $(62,3 \%)$ e a qualidade de ensino $(86,9 \%)$ atrelados à universidade são pontos que se destacaram como grande influência para os respondentes. Por esse fato, são pontos interessantes a serem utilizados em ações de marketing de universidades, sendo elas utilizadas com intuito de despertar uma emoção específica ou não.

É importante citar que o reconhecimento e a qualidade de ensino foram pontos utilizados nas peças criadas no questionário de universidade, visto que se mostraram relevantes desde a pesquisa qualitativa.

Outros pontos citados como fatores que possam influenciar na escolha de uma universidade foram: as instalações, a indicação e o processo de entrada. É possível utilizá-los da mesma forma que os fatores já citados, atrelados ou não a uma emoção. 


\section{Tabela 2 - Fatores de Influência (Universidade)}

\begin{tabular}{|c|c|c|c|c|c|c|c|c|c|c|c|}
\hline & Discord & ompletamente & Discordo & parcialmente & & ferente & Concordo & parcialmente & Concordo & mpletamente & Total \\
\hline Pergunta & $\%$ & $\mathrm{n}^{0}$ de resp. & $\%$ & $n^{0}$ de resp. & $\%$ & $n^{0}$ de resp. & $\%$ & $n^{0}$ de resp. & $\%$ & $n^{0}$ de resp. & \\
\hline $\begin{array}{l}\text { O CUSTO da faculdade } \\
\text { influencia a minha escolha. }\end{array}$ & $3.1 \%$ & 4 & $1.5 \%$ & 2 & $12.3 \%$ & 16 & $32.3 \%$ & 42 & $50.8 \%$ & 66 & 130 \\
\hline $\begin{array}{l}\text { O RECONHECIMENTO da } \\
\text { faculdade influencia a minha } \\
\text { escolha. }\end{array}$ & $0.8 \%$ & 1 & $3.9 \%$ & 5 & $6.2 \%$ & 8 & $26.9 \%$ & 35 & $62.3 \%$ & 81 & 130 \\
\hline $\begin{array}{l}\text { A QUALIDADE DE ENSINO } \\
\text { da faculdade influencia a } \\
\text { minha escolha. }\end{array}$ & $0.00 \%$ & 0 & $0.00 \%$ & 0 & $0.8 \%$ & 1 & $12.3 \%$ & 16 & $86.9 \%$ & 113 & 130 \\
\hline $\begin{array}{l}\text { As INSTALAÇÕES da } \\
\text { faculdade influenciam a minha } \\
\text { escolha. }\end{array}$ & $0.00 \%$ & 0 & $2.3 \%$ & 3 & $14.6 \%$ & 19 & $58.5 \%$ & 76 & $24.6 \%$ & 32 & 130 \\
\hline $\begin{array}{l}\text { A INDICAÇÂO de alguém } \\
\text { influencia a minha escolha de } \\
\text { faculdade. }\end{array}$ & $3.9 \%$ & 5 & $7.7 \%$ & 10 & $36.2 \%$ & 47 & $46.9 \%$ & 61 & $5.4 \%$ & 7 & 130 \\
\hline $\begin{array}{l}\text { O PROCESSO DE } \\
\text { ENTRADA (provas e/ou } \\
\text { entrevistas) influencia a minha } \\
\text { escolha. }\end{array}$ & $3.9 \%$ & 5 & $6.9 \%$ & 9 & $32.3 \%$ & 42 & $45.4 \%$ & 59 & $11.5 \%$ & 15 & 130 \\
\hline $\begin{array}{l}\text { Uma PROPAGANDA da } \\
\text { faculdade influencia a minha } \\
\text { escolha. }\end{array}$ & $10.0 \%$ & 13 & $13.9 \%$ & 18 & $42.3 \%$ & 55 & $25.4 \%$ & 33 & $8.5 \%$ & 11 & 130 \\
\hline
\end{tabular}

Analisando a propaganda que buscava incitar a felicidade, é possível concluir que causou um efeito positivo na decisão de compra daqueles que frequentam ou buscam uma universidade, levando 60 respondentes $(46,2 \%)$ a concordarem com o fato de que a propaganda causou vontade de frequentar a universidade responsável pela peça. O número ultrapassa até aqueles que mostraram indiferença à peça (52 respondentes, 40\%).

Pode-se observar, também, que a peça causou alto grau de "satisfação", "contentação", "felicidade" e "alegria". Somados, esses sentimentos chegam a 148 registros $(59,7 \%)$ entre os respondentes. Como explicado anteriormente, tais sentimentos são tomados por sinônimos de "felicidade", o que confirma que a peça criada despertou a emoção pela qual foi projetada. 
Gráfico 3 - Likert Universidade (Felicidade)

Faculdade - Felicidade

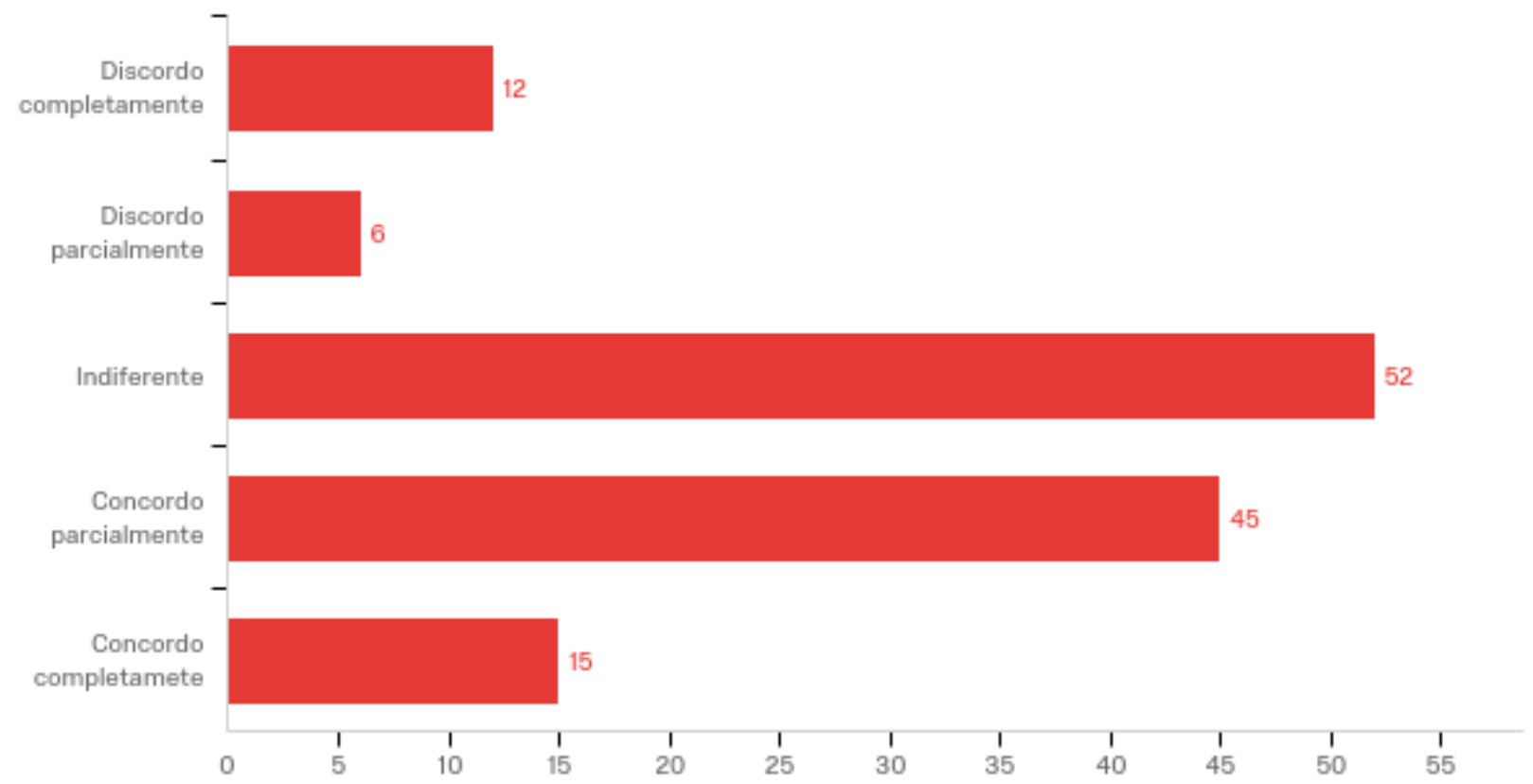

Gráfico 4 - Escala de Sensações (Universidade - Felicidade)

Faculdade - Felicidade

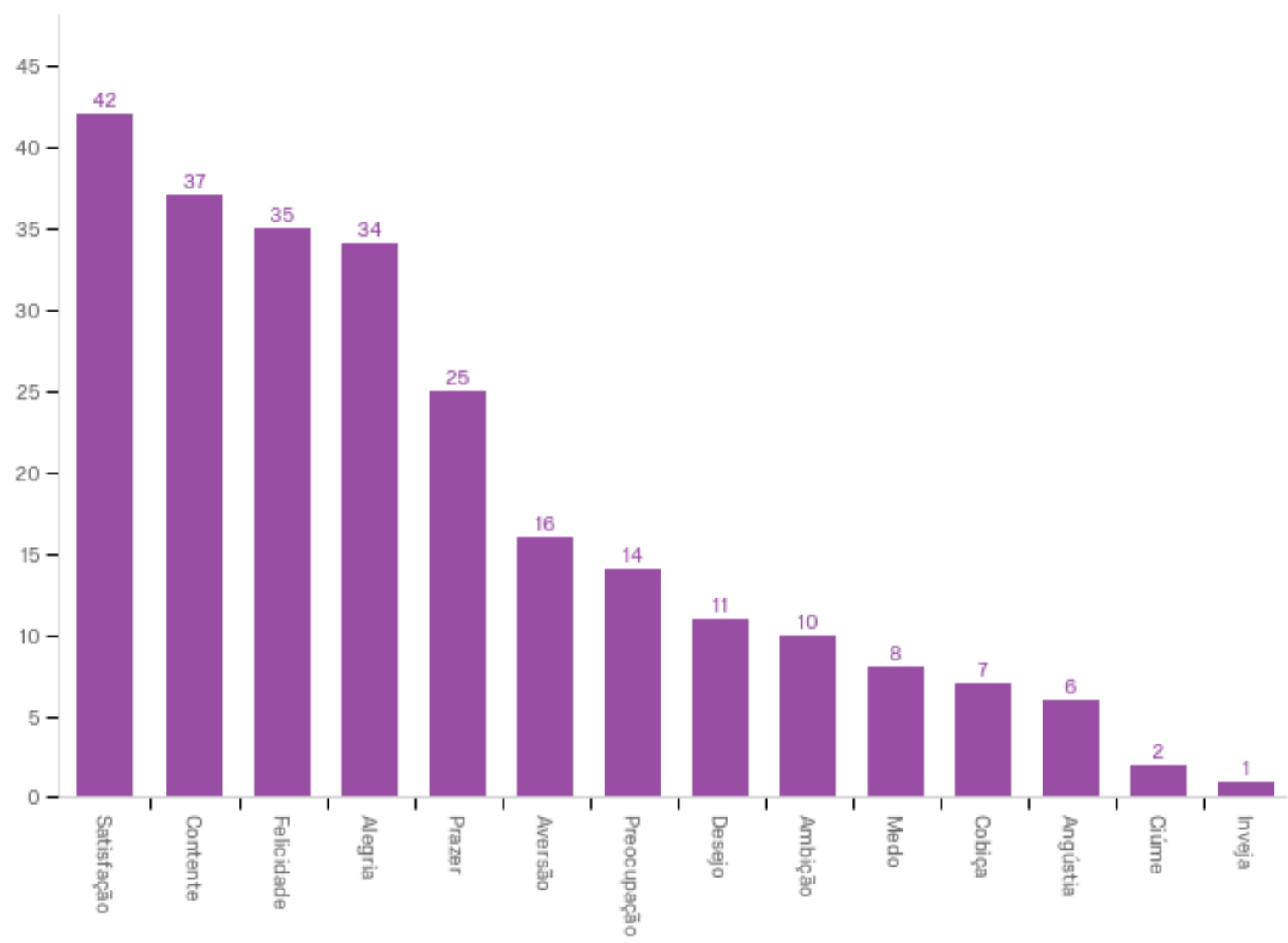


A propaganda que buscava causar "medo" no consumidor causou grande aversão nos respondentes, concluindo assim que tal emoção não seria indicada em uma propaganda ligada à universidade. O número de possíveis consumidores do serviço que não tiveram vontade de frequentar a universidade que utilize esse tipo de divulgação chegou a 71 respondentes $(54,62 \%)$.

\section{Gráfico 5 - Likert Universidade (Medo)}

\section{Faculdade - Medo}

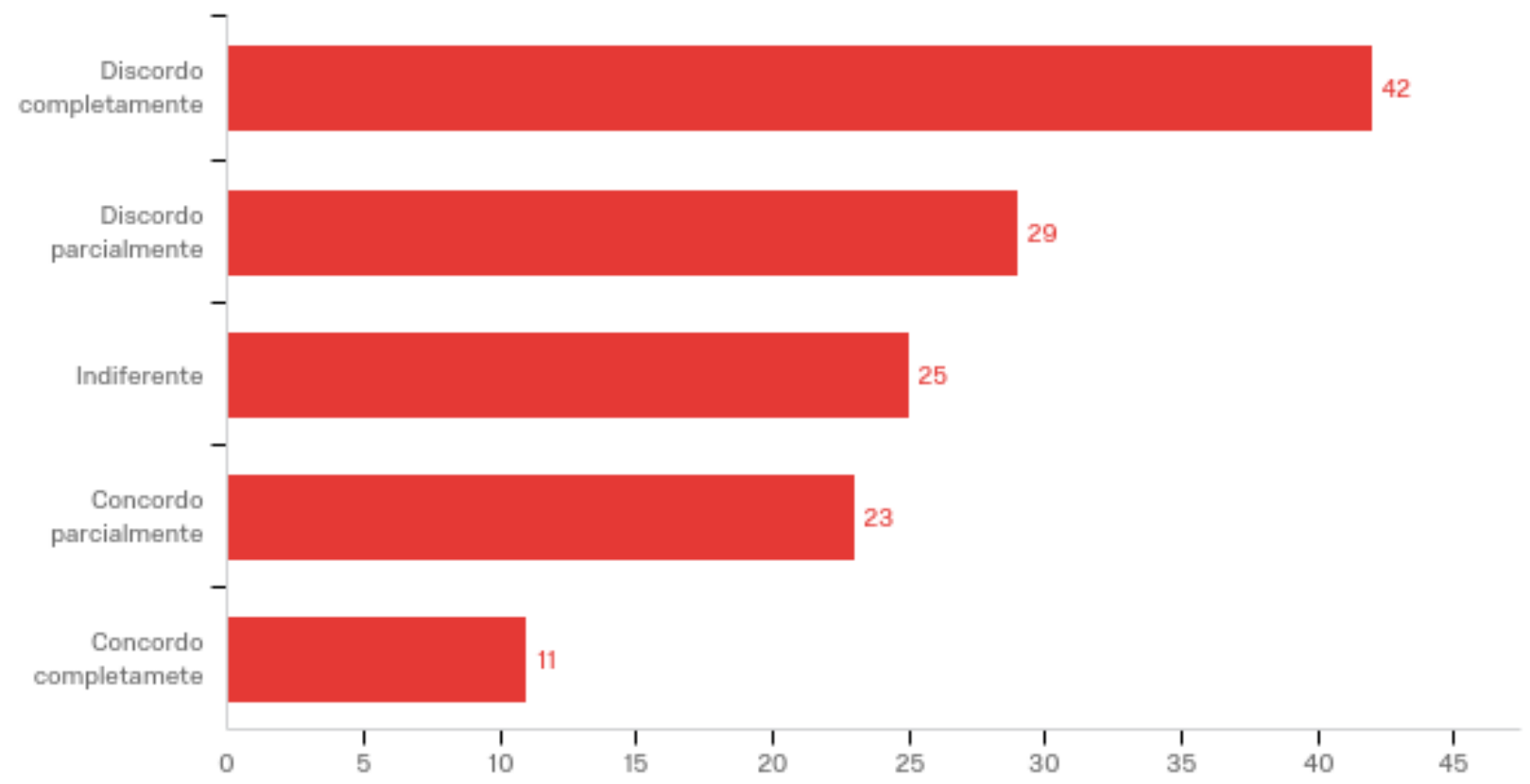

Pode-se concluir que, apesar da peça ter causado rejeição frente aos respondentes, ela estimulou a emoção para qual foi feita: o "medo". Como visto anteriormente, o "medo" tem como sinônimo as palavras "preocupação", "aversão" e "angústia", que juntos ao próprio "medo" foram as sensações que mais foram marcadas como sentidas ao observar a peça. Juntas, elas somam 190 marcações no questionário, representando $86,0 \%$ das sensações apontadas como sentidas na mesma pergunta. 
Gráfico 6 - Escala de Sensações (Universidade - Medo)

\section{Faculdade - Medo}

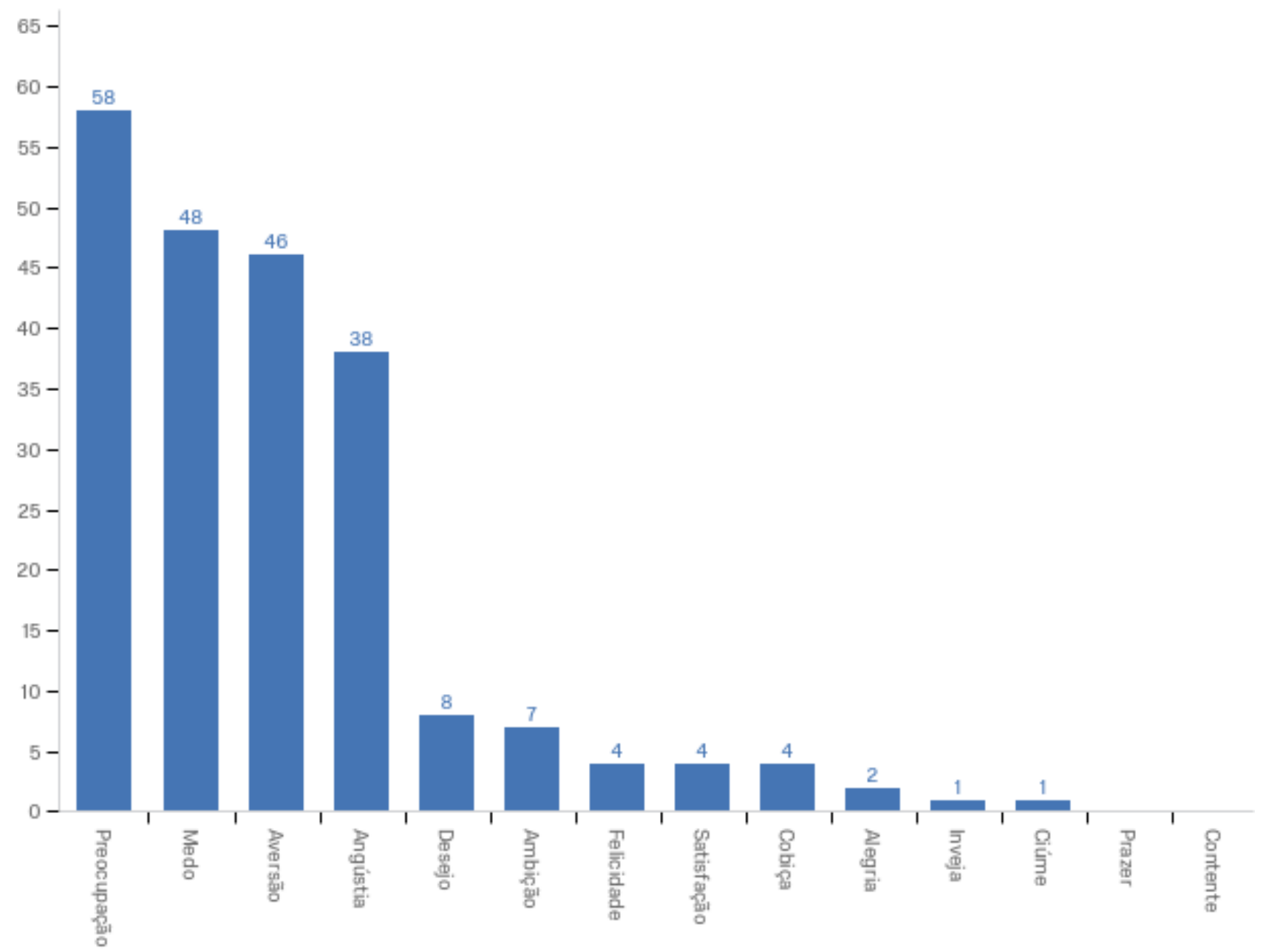

A peça utilizada como apoio, criada sem intuito de incitar qualquer tipo de emoção, obteve um retorno positivo dos respondentes, alcançando 56 respostas $(43,1 \%)$ das pessoas que frequentariam a universidade que utilizasse a propaganda exposta. 


\section{Gráfico 7 - Likert Universidade (Apoio)}

\section{Faculdade - Teste}

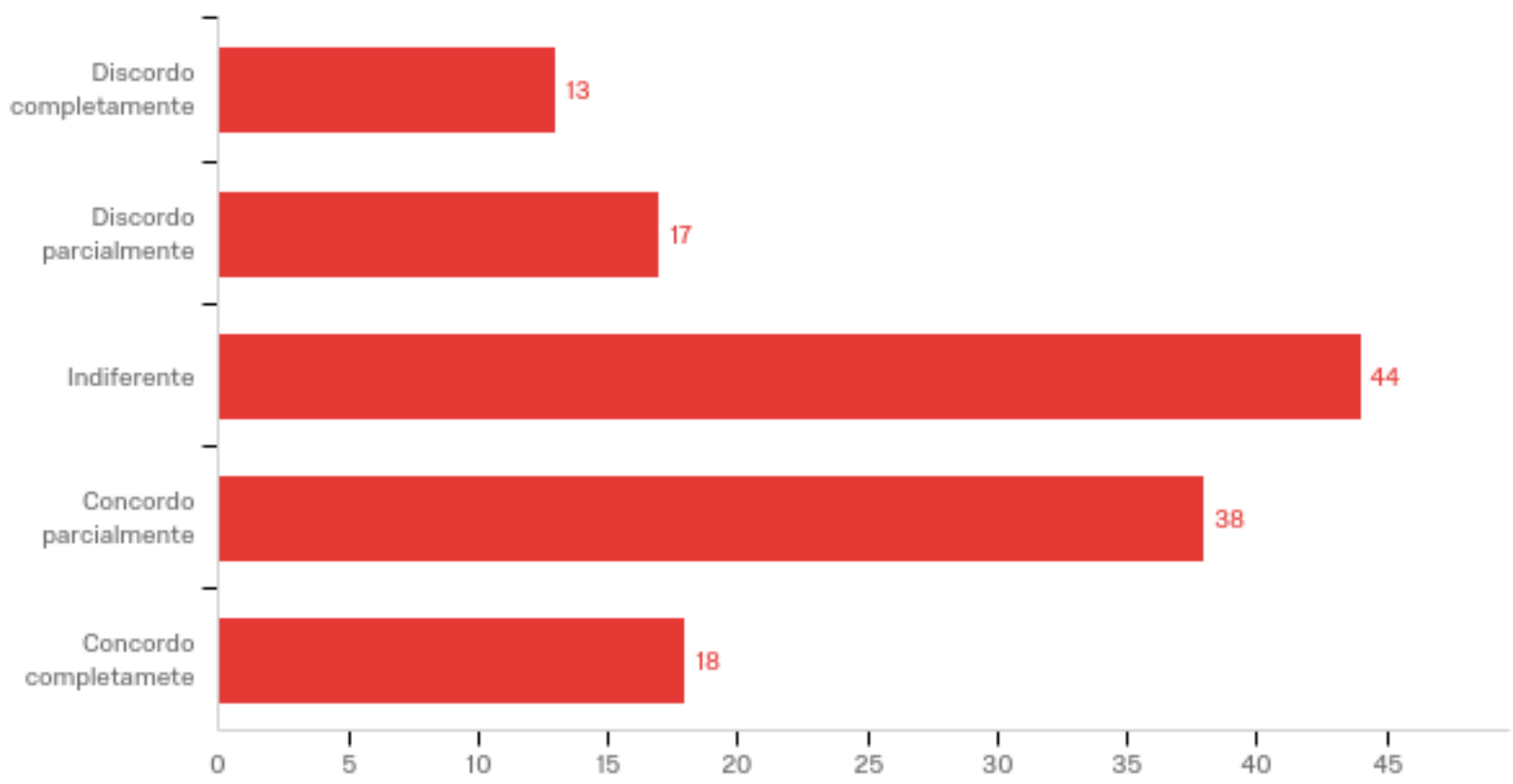

Mesmo sendo criada sem intenção de despertar nenhuma emoção, pode-se medir que a peça de apoio causou grande "satisfação" nos respondentes, sensação essa ligada a felicidade.

É importante apontar que ela trouxe 32 sentimentos (considerando como sentimento cada marcação no questionário) de aversão à peça, sensação essa ligada à emoção "medo", que pode ter sido despertada por respondentes que reconheceram a propaganda exposta e, ao ligar a marca que a utiliza despertaram tal emoção.

Excluindo tal fator, a peça despertou no geral um alto grau de sensações ligadas a "felicidade", sendo esse talvez o fator que fez com que os respondentes se inclinarem a responder que cursariam a universidade que utiliza tal peça, como aconteceu com o caso da peça que buscava despertar a emoção "felicidade". 
Gráfico 8 - Escala de Sensações (Universidade - Apoio)

Faculdade - Teste

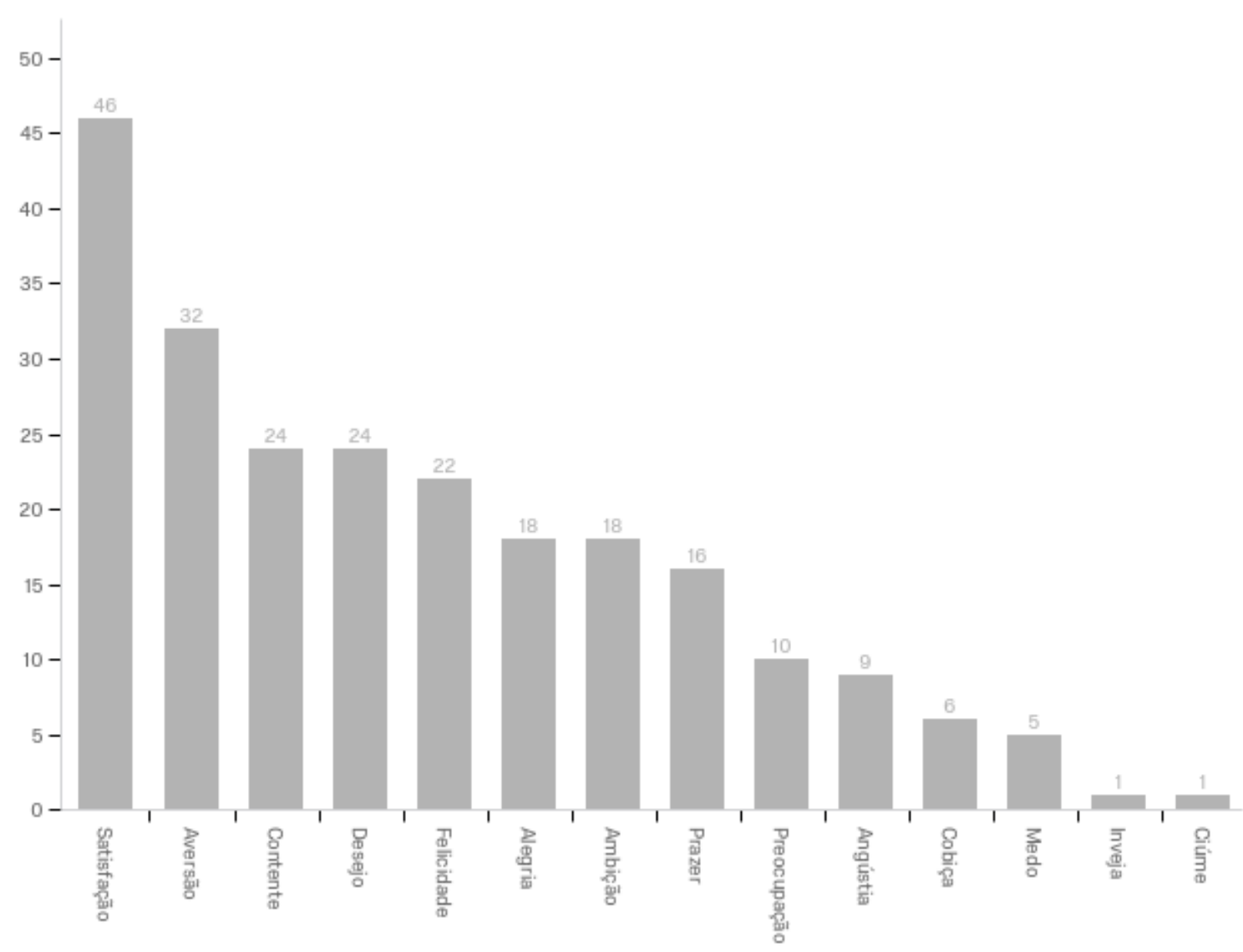

Pode-se observar que a propaganda que buscava causar inveja obteve alto efeito positivo naqueles que foram expostos a ela na pesquisa. 83 respondentes $(63,8 \%)$ concordaram que a peça fez que eles tenham vontade de cursar a universidade que utilizasse esse tipo de propaganda, influenciando assim a decisão de compra dos respondentes. 


\section{Gráfico 9 - Likert Universidade (Inveja)}

\section{Faculdade - Inveja}

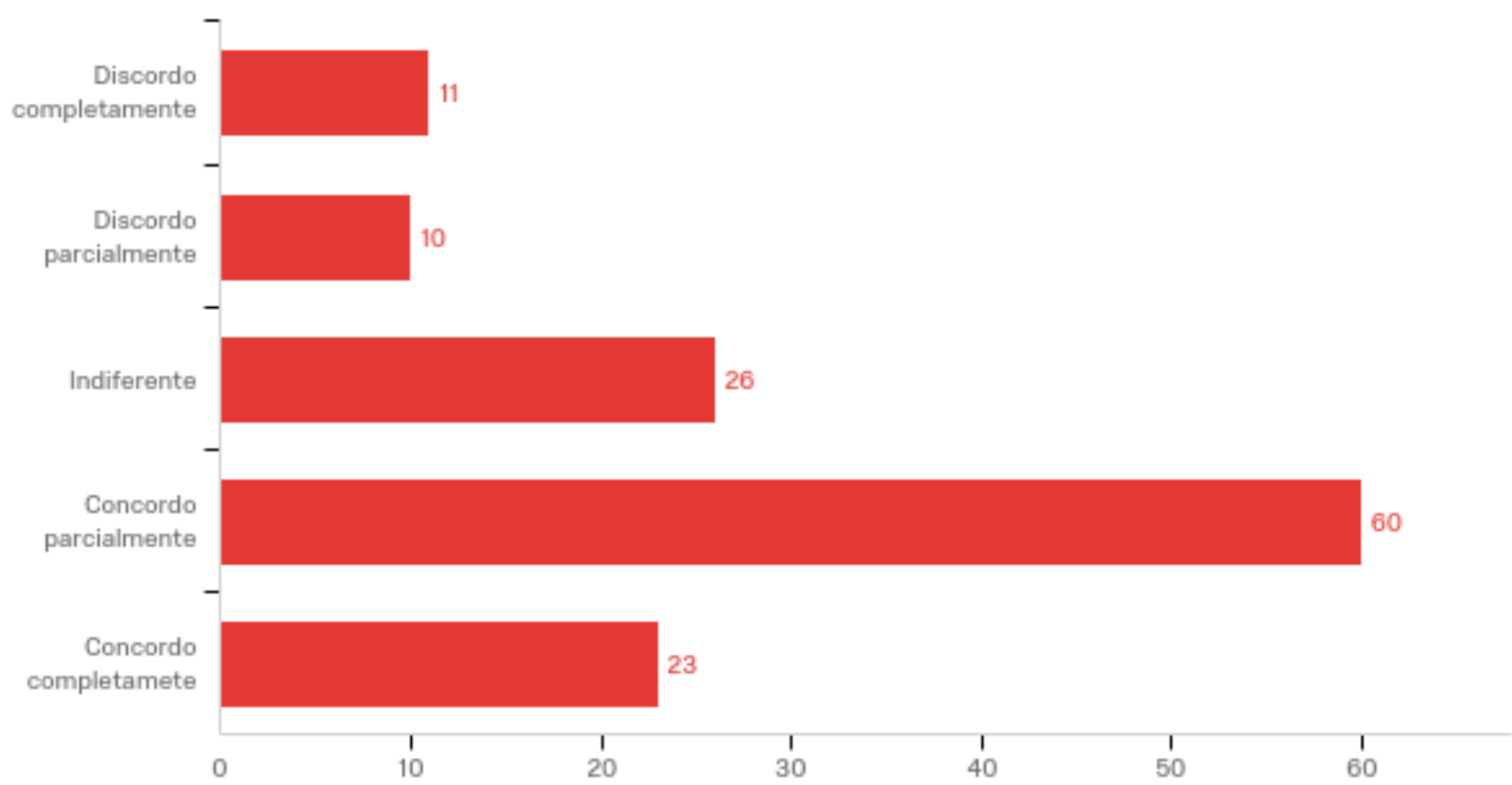

O gráfico 10 nos traz como principais sensações apontadas "desejo" e "ambição", ambas ligadas a emoções que buscava ser estimulada na peça, a "inveja". É importante observar que, mesmo tendo com principais sensações o "desejo" e "ambição", a peça despertou um alto grau de "preocupação", ligado ao "medo" e "satisfação", ligada a "felicidade". É possível que, ao despertar "inveja", a peça tenha levado o respondente a se avaliar frente o que deseja, despertando assim uma sensação negativa "preocupação" ao pensar que o objetivo possa não ser alcançado; e uma sensação positiva "satisfação" ao pensar que o objetivo desejado será alcançado. 


\section{Faculdade - Inveja}

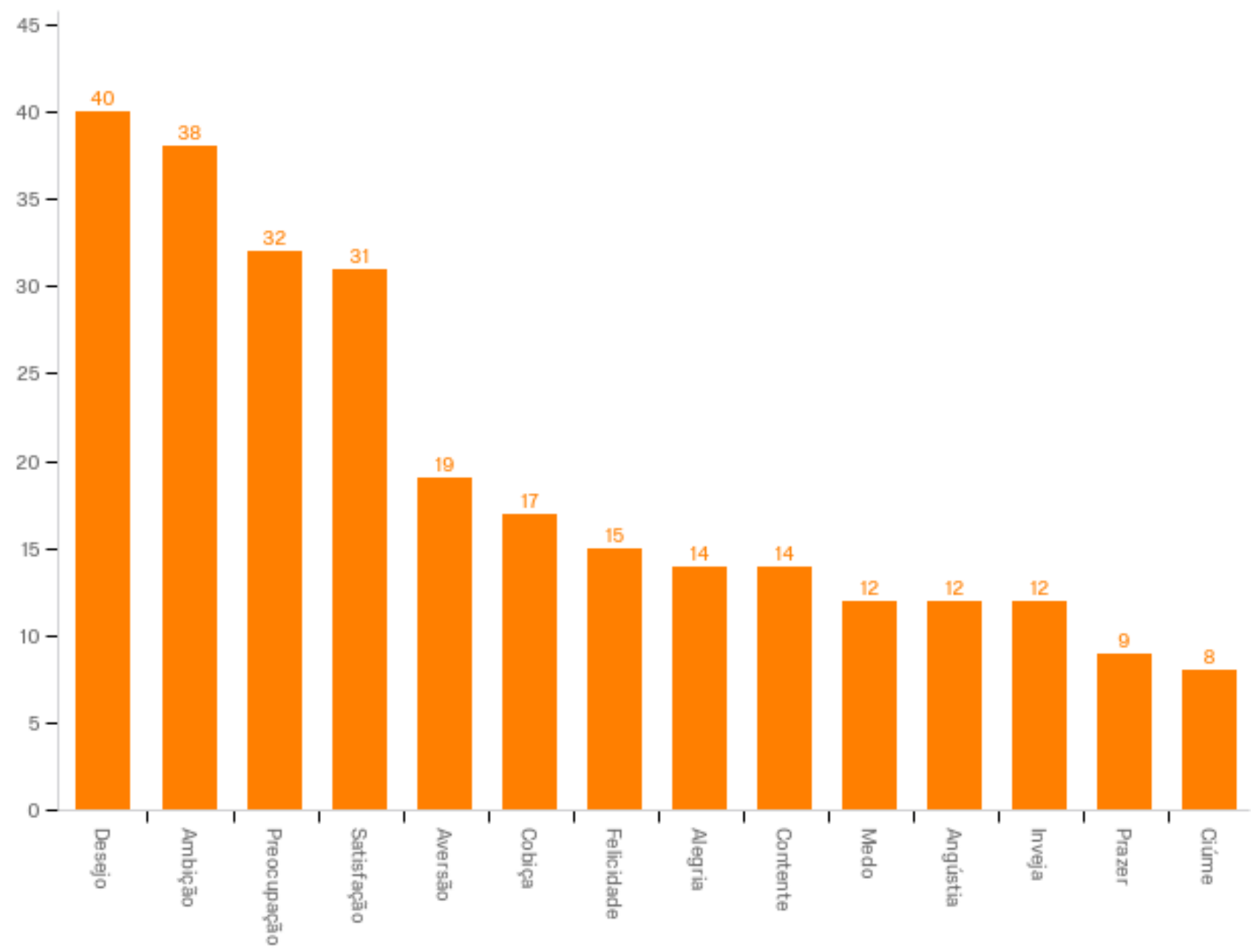

Como forma de comparar os resultados obtidos pelas mídias apresentadas, foi realizada uma análise por meio da Escala Likert de cada uma das questões que buscavam medir a intenção de compra dos respondentes (Questão 3, exemplificada no Anexo 10). Foram atribuídos os pesos de -2 (para discordo completamente) a 2 (para concordo completamente) e somados os resultados.

Ao comparar os dados obtidos em todas as perguntas relacionadas as emoções que utilizaram a Escala Likert, é possível identificar que a propaganda que melhor resultado obtido na influência da decisão de compra foi a propaganda que buscou despertar "inveja" nos consumidores, seguida assim pela que 
buscou despertar "felicidade", a propaganda de apoio e, por fim, a propaganda que buscou incitar "medo".

Tabela 3 - Análise Escala de Likert - Universidade

\begin{tabular}{|c|c|c|c|}
\hline \multicolumn{4}{|c|}{ Likert - Universidade } \\
\hline \multicolumn{2}{|l|}{ Felicidade } & \multicolumn{2}{|l|}{ Medo } \\
\hline Discordo Completamente & -24 & Discordo Completamente & -84 \\
\hline Discordo Parcialmente & -6 & Discordo Parcialmente & -29 \\
\hline Neutro & 0 & Neutro & 0 \\
\hline Concordo Parcialmente & 45 & Concordo Parcialmente & 23 \\
\hline Concordo Completamente & 30 & Concordo Completamente & 22 \\
\hline Soma & 45 & Soma & -68 \\
\hline \multicolumn{2}{|l|}{ Apoio } & \multicolumn{2}{|l|}{ Inveja } \\
\hline Discordo Completamente & -26 & Discordo Completamente & -22 \\
\hline Discordo Parcialmente & -17 & Discordo Parcialmente & -10 \\
\hline Neutro & 0 & Neutro & 0 \\
\hline Concordo Parcialmente & 38 & Concordo Parcialmente & 60 \\
\hline Concordo Completamente & 36 & Concordo Completamente & 46 \\
\hline Soma & 31 & Soma & 74 \\
\hline
\end{tabular}

\subsection{Questionário - Shampoo}

\subsubsection{Análise Demográfica}

A amostra foi composta de $67,2 \%$ de respondentes do sexo feminino e $32,1 \%$ do sexo masculino, obtendo dados também de respondentes que não se identificam com nenhum dos dois sexos, se mostrando assim consideravelmente representativa no aspecto gênero.

Quando analisamos a idade dos respondentes, a amostra obteve 16,8\% das respostas de pessoas entre 17 e 20 anos, 39,7\% de pessoas entre 21 e 25 anos, $28,1 \%$ de pessoas entre 26 e 30 anos, $4,6 \%$ de pessoas entre 31 e 35 anos e $10,7 \%$ de pessoas com 36 anos ou mais. 


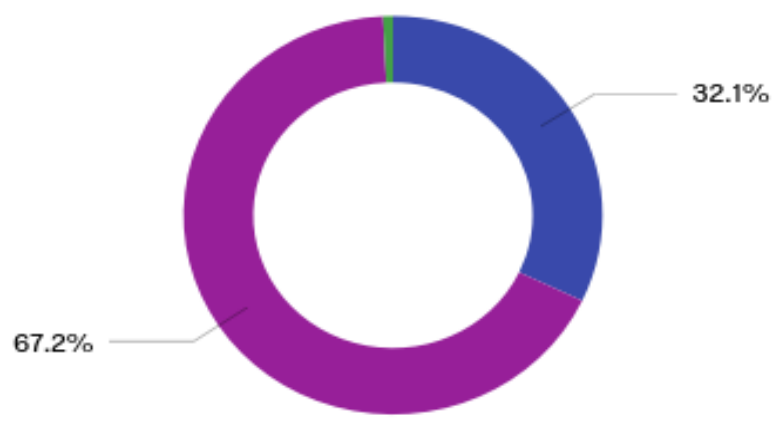

Masculino Feminino Outro

Como pode-se observar no gráfico 12, a amostra obteve um alto número de respondentes com graduação incompleta ou completa ( $77,1 \%$ da amostra). Outros níveis de escolaridade também se mostram presentes na pesquisa, desde ensino médio completo até doutorado completo, tendo uma representação de um público variado. 


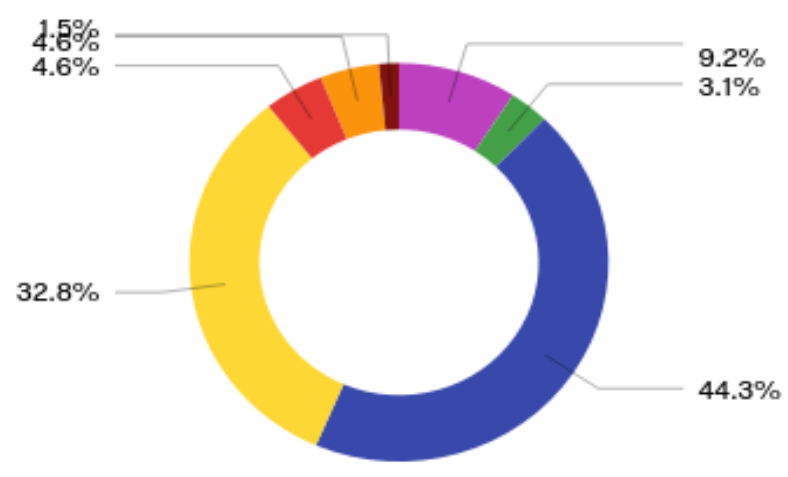

Ensino Médio Completo

Curso Técnico Completo

Graduaçāo Incompleta

Utilizando como base o IBGE 2015, atualizando apenas o salário mínimo, foi possível obter a seguinte divisão de classes na amostra: 10,8\% dos respondentes correspondem a classe E, 19,2\% correspondem a classe D, 30,8\% a classe $C, 23,1 \%$ a classe $B$ e $16,1 \%$ a classe $A$.

Tabela 4 - Divisão por Classe Social (Shampoo)

\begin{tabular}{|l|l|l|l|}
\hline \multicolumn{4}{|l|}{ Classe Social } \\
\hline Faixa Salarial $(R \$)$ & Faixa Salarial $(S M)$ & Classe Social & $\%$ da Amostra \\
\hline Até $R \$ 1.874,00$ & Até 2 SM & Classe E & $10,8 \%$ \\
\hline Entre $R \$ 1.874,01$ e $R \$ 3.748,00$ & 2 a 4 SM & Classe D & $19,2 \%$ \\
\hline Entre $R \$ 3.748,01$ e $R \$ 9.370,00$ & 4 a 10 SM & Classe C & $30,8 \%$ \\
\hline Entre $R \$ 9.370,01$ e $R \$ 18.740,00$ & 10 a 20 SM & Classe B & $23,1 \%$ \\
\hline$R \$ 18.740,01$ ou mais. & Acima de 20 SM & Classe A & $16,1 \%$ \\
\hline
\end{tabular}

Legenda: SM significa salário mínimo.

\subsubsection{Análise Comportamental}

Como forma de entender se o produto trabalhado possuía alguém relevante na decisão de compra, foi feita a pergunta aos respondentes relacionada a escolha do shampoo. Como pode ser observado, a maioria escolhe seu próprio shampoo, representando $92,4 \%$ da amostra. Aqueles que não escolhem seu próprio shampoo, indicaram como principal responsável pela 
escolha suas mães. Esse fator deve ser considerado em pesquisas futuras e, se possível, utilizado como insumo na estratégia de marketing das empresas. Mesmo não sendo responsáveis pela escolha, eles foram considerados na amostra por possibilidade de influenciar na compra.

\section{Gráfico 13 - Decisão de Compra (Shampoo)}

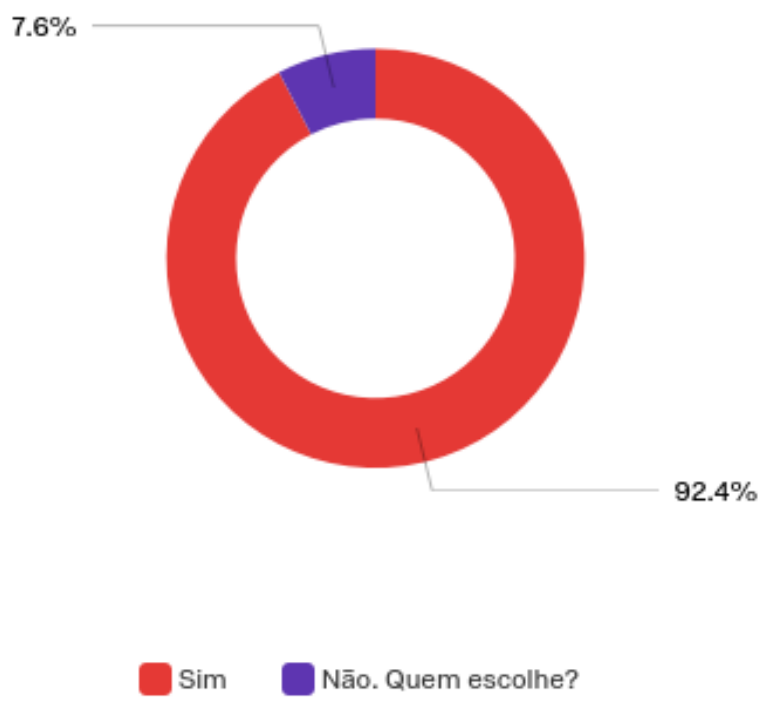

Observando a tabela 5 gerada a partir dos insumos que buscam analisar a influência de certos fatores na decisão de compra do consumidor de shampoo, pode-se observar que a pesquisa trouxe como relevantes os fatores "marca" e "qualidade". Tal resultado é de extrema importância, visto que o presente estudo foi feito sem a presença de marcas, o que valida a influência que uma marca poderia ter sobre as peças criadas. Estudos futuros podem buscar um efeito entre o branding emocional e o design emocional como forma de entender até que ponto o branding emocional pode afetar uma peça criada sobre uma estratégia de marketing que utilize o design emocional em comparação com uma estratégia que não utilize a metodologia.

É interessante o fator "qualidade" ser o de segunda maior expressão nos dados, visto que a qualidade do shampoo requer uma validação individual, sendo necessária uma solução para cada tipo de cabelo existente. Essa estratégia de criação de shampoos para cabelos específicos já é utilizada pelas empresas hoje (sendo citado até mesmo em nossa pesquisa qualitativa), porém como forma de 
apresentar o fator qualidade, as peças trabalhadas buscaram o significado de cabelo perfeito apresentado na pesquisa qualitativa.

Fatores já conhecidos pelos profissionais de marketing como o preço e outros ligados a outras áreas como a disponibilidade no ponto de venda (atrelada à logística) já se mostram como pontos praticados pela indústria hoje e apareceram validados como fatores importantes a serem considerados pelos consumidores.

\section{Tabela 5 - Fatores de Influência (Shampoo)}

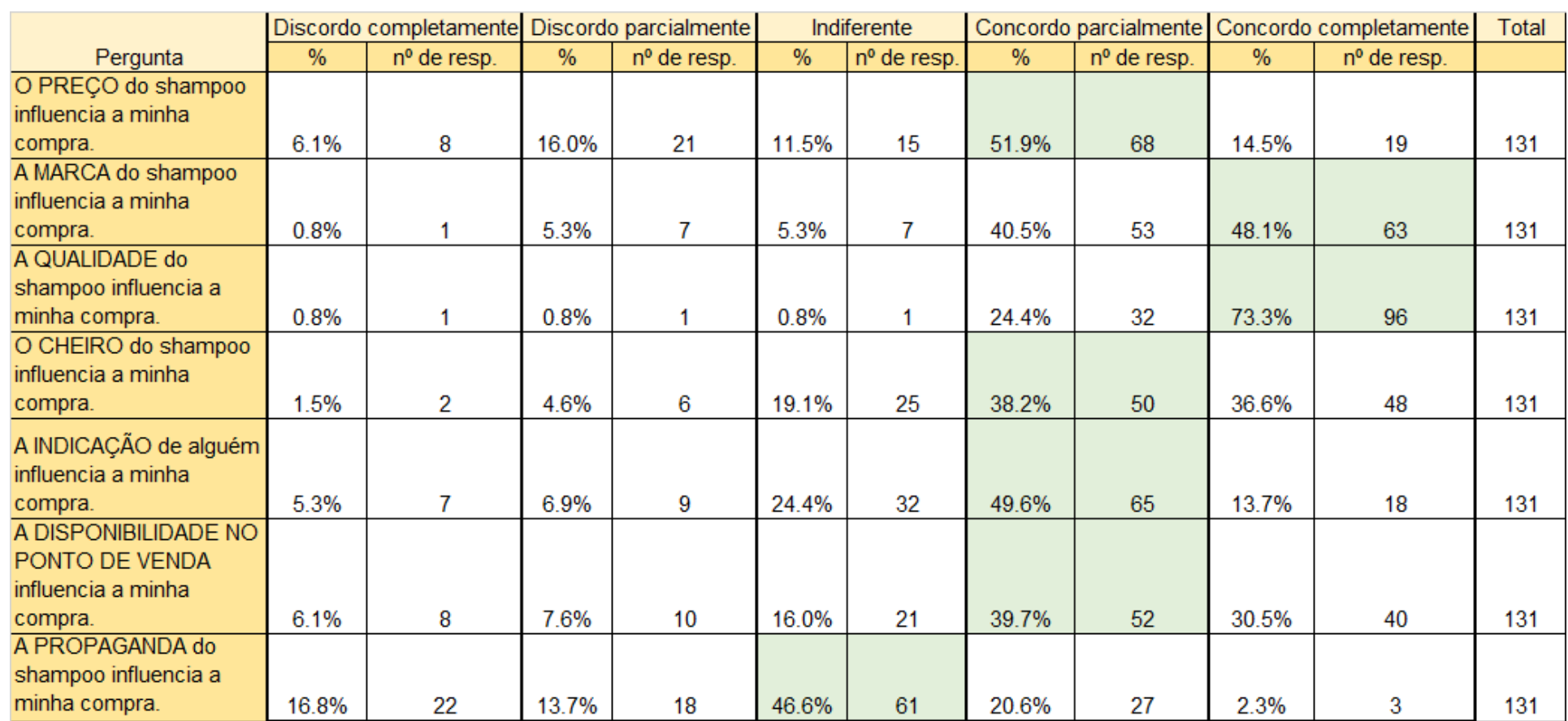

Ao analisar os dados relacionados a peça de propaganda que buscava despertar felicidade, foi possível validar a importância que tal emoção teve sobre o produto. 68 respondentes $(51,9 \%)$ concordaram com o fato de que tal propaganda os fez querer comprar o produto que a utilizasse. 
Gráfico 14 - Likert Shampoo (Felicidade)

Shampoo - Felicidade

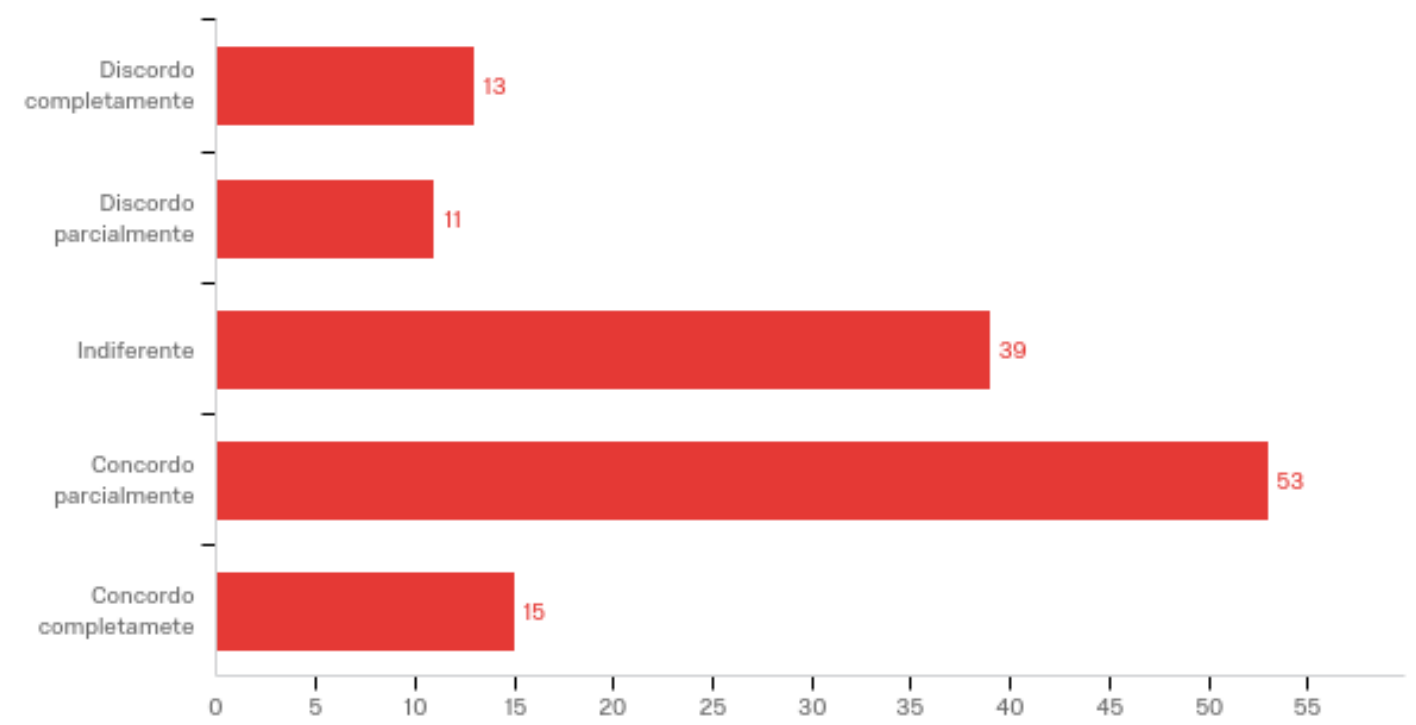

Ao serem questionados sobre possíveis sensações sentidas ao observar a peça, os resultados obtidos foram em sua maioria ligados às sensações "alegria", "satisfação", "felicidade" e "contente", sendo todas essas sensações ligadas à emoção desejada a ser despertada, a "felicidade". Juntas, elas somaram 171 marcações no questionário (63,6\%).

Tal fato mostra que a peça obteve o resultado esperado, despertando assim a emoção "felicidade" naqueles que a avaliaram. 
Gráfico 15 - Escala de Sensações (Shampoo - Felicidade) Shampoo - Felicidade

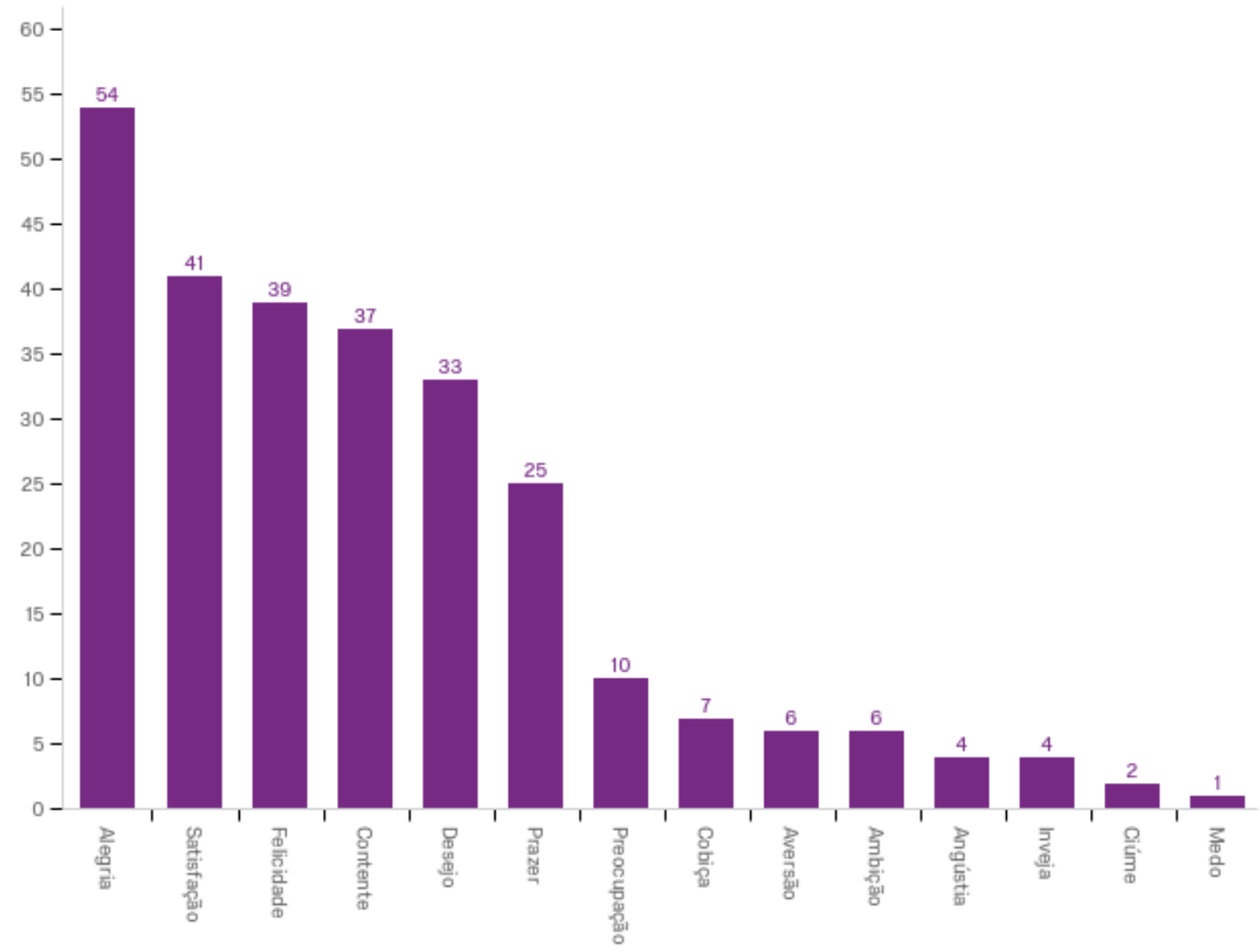

Assim como na peça que visava despertar medo atrelado a universidade, a peça de shampoo que buscava a mesma emoção também obteve grande rejeição na amostra. O grau de discordância frente ao produto que utilizasse tal tipo de propaganda chegou a 81 respostas negativas $(61,8 \%)$.

Tal fato mostra que não deve ser utilizada tal tipo de propaganda no produto trabalhado, trazendo reações negativas para o produto. É possível tentar entender esse fator com futuros estudos que busquem entender se é uma questão geográfica essa rejeição ou se é um senso comum, como já estudada em outras áreas citadas no referencial teórico. Estudos que busquem entender se tal rejeição se mostra atrelada a certos tipos de produtos ou serviços também são válidas para que se descubra se tal emoção pode ser usada em estratégias de outros produtos ou serviços, como ONGs, por exemplo. 
Gráfico 16 - Likert Shampoo (Medo)

Shampoo - Medo

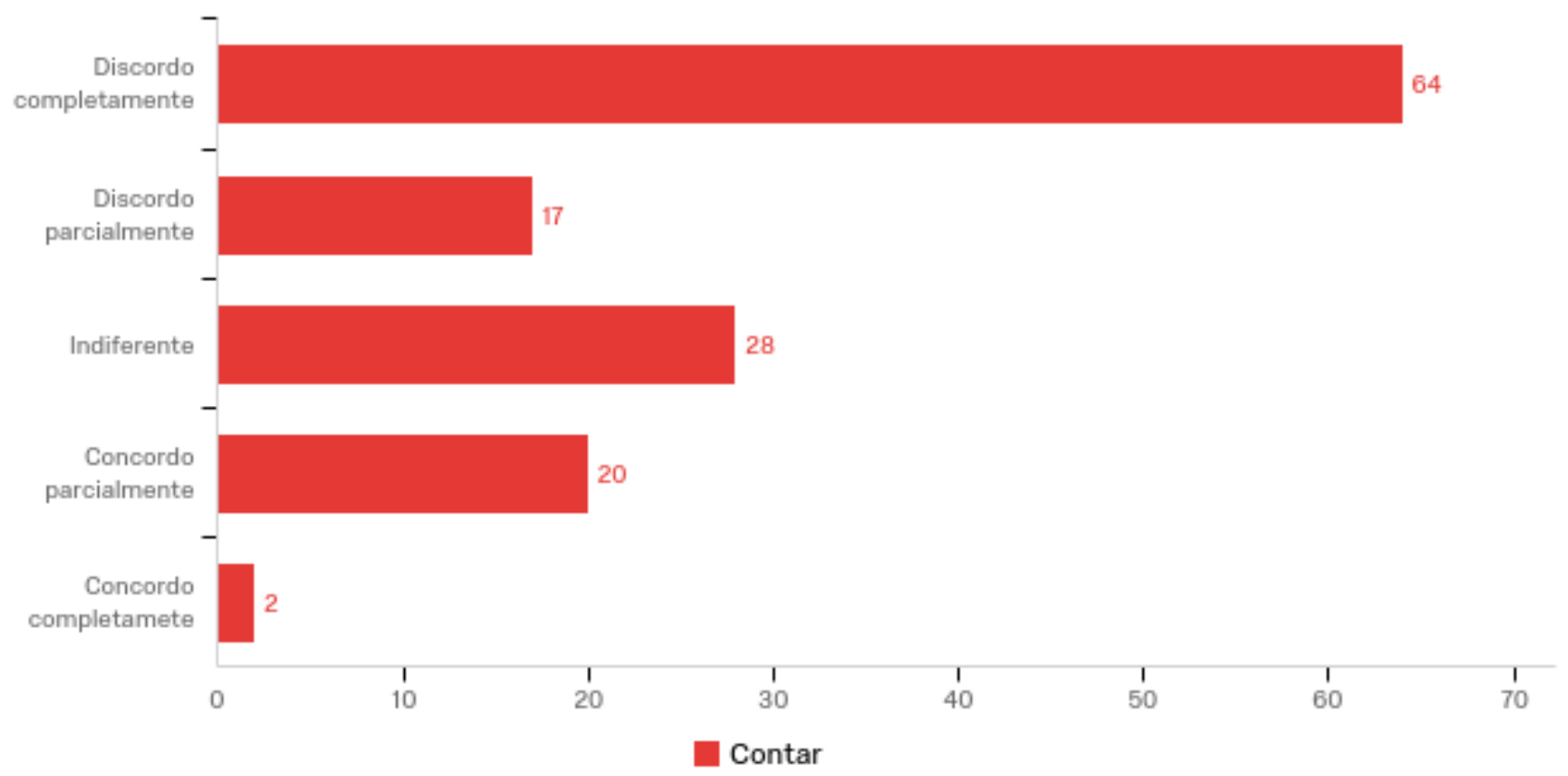

Assim como a peça que se mostrou apta a despertar felicidade, a propaganda buscava despertar medo nos respondentes se mostrou válida, obtendo como principais sensações àquelas ligadas ao "medo": "aversão", "preocupação" e "angústia", em uma somatória de 162 sensações atreladas ao "medo" (85,7\%). 


\section{Shampoo - Medo}

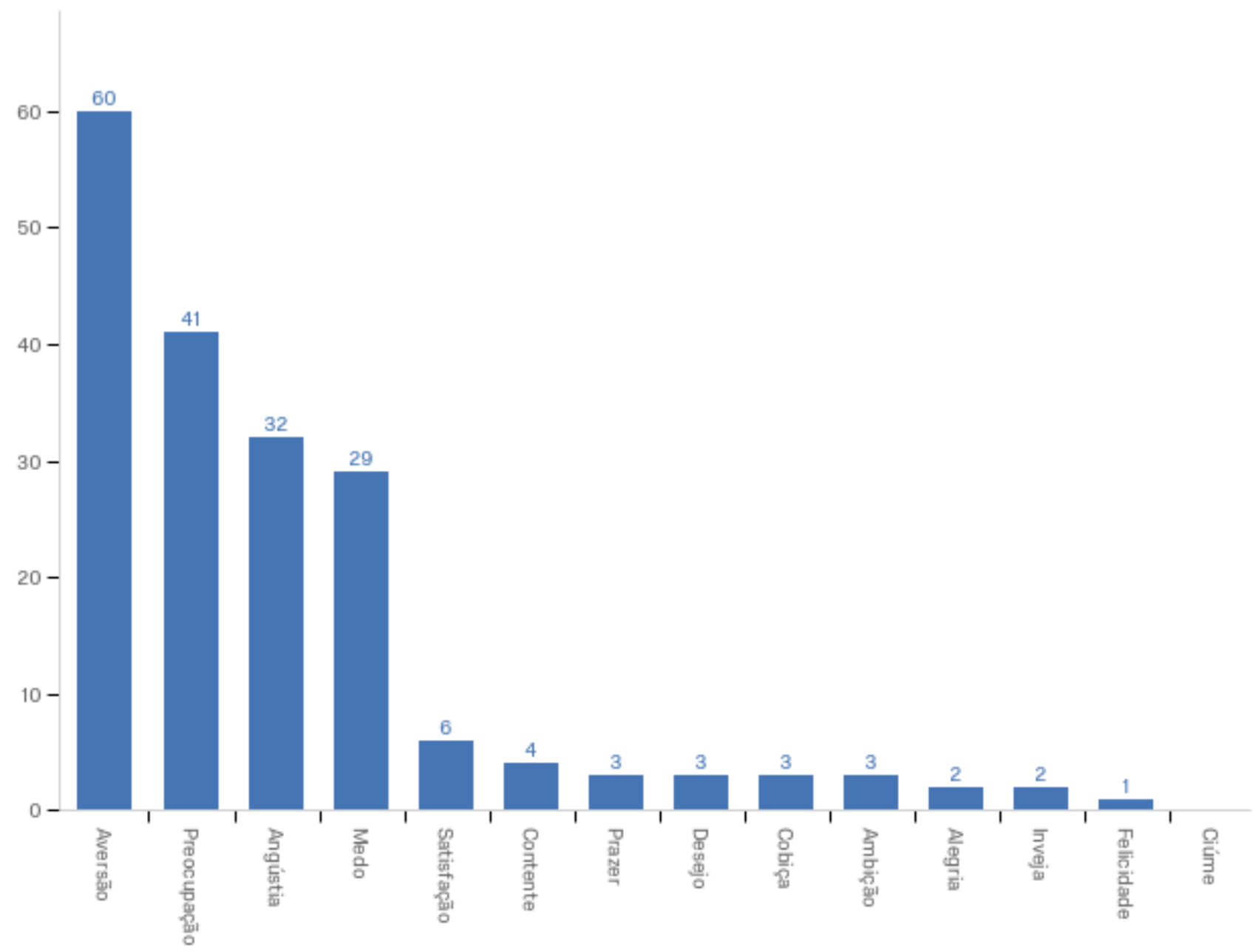

A peça de apoio utilizada na pesquisa obteve alto número de aceitação entre os usuários de shampoo, alcançando 78 respostas positivas frente ao shampoo que utilize tal tipo de divulgação. A propaganda apresenta uma fórmula conhecida na indústria, atrelando ao shampoo a validação de uma porta voz conhecida (no caso, a cantora internacional Selena Gomez). Esse uso de uma celebridade liga o shampoo a dois fatores de influência validados na pesquisa, 0 fator "qualidade" e "indicação". 


\section{Shampoo - Teste}

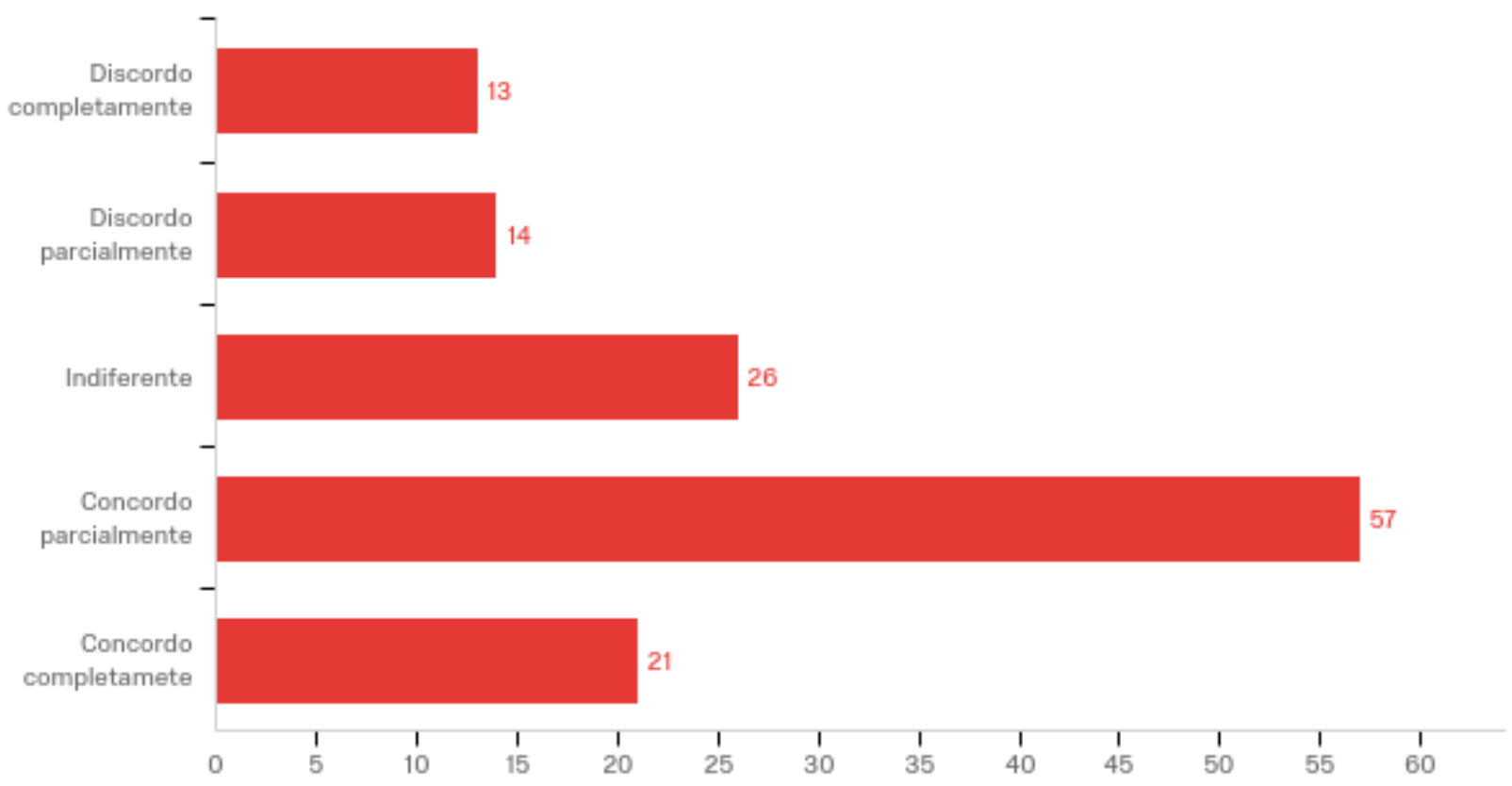

Ao buscar entender que sensações a peça de apoio causou nos usuários, foi possível observar que a mídia despertou alto grau de "desejo" (ligado a inveja), seguido de "satisfação" (ligado a felicidade) e "ambição" (ligado a inveja).

É interessante observar que uma peça que influencie a decisão de compra de forma positiva como essa possua alto grau de duas emoções trabalhadas no presente estudo: a "felicidade", validada como emoção indicada a ser trabalhada junto ao produto; e "inveja", emoção a ser analisada a seguir. 


\section{Shampoo - Teste}

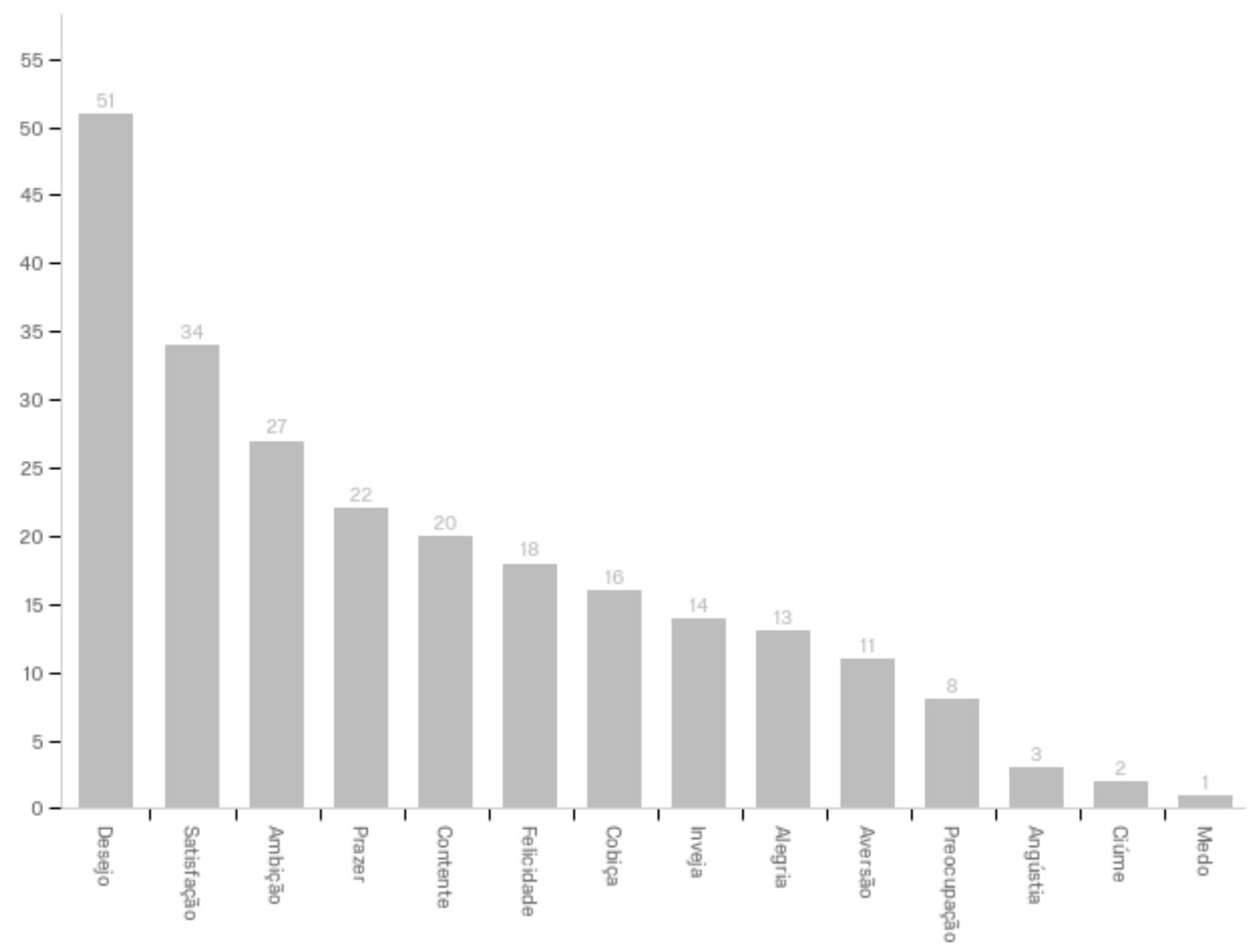

A peça que buscou um efeito na decisão de compra ao utilizar a emoção "inveja" trouxe um resultado bem divergente. 41 respondentes $(31,3 \%)$ tiveram um efeito positivo em sua decisão de compra, se mostrando inclinados a consumir 0 produto que utilize da propaganda exposta, enquanto 52 respondentes $(39,7 \%)$ mostraram rejeição ao produto frente a propaganda apresentada. Um dado considerável foi o alto número de respostas que se mostraram indiferente à peça (38 respondentes, 29,0\%).

Como o processo de construção da peça utilizou uma inveja produzida pela ascensão profissional junto ao cabelo indicado como desejado, esse fator deve ser revisado para possíveis criações futuras que busquem a emoção desejada de forma positiva. A peça de apoio, analisada anteriormente, causou 
inveja ao utilizar uma porta voz conhecida com o cabelo desejado, outro forma de causar "inveja" como visto pelos dados, sendo esse modo apontado de forma mais efetiva para o produto trabalhado com o utilizado na pesquisa. 
Shampoo - Inveja

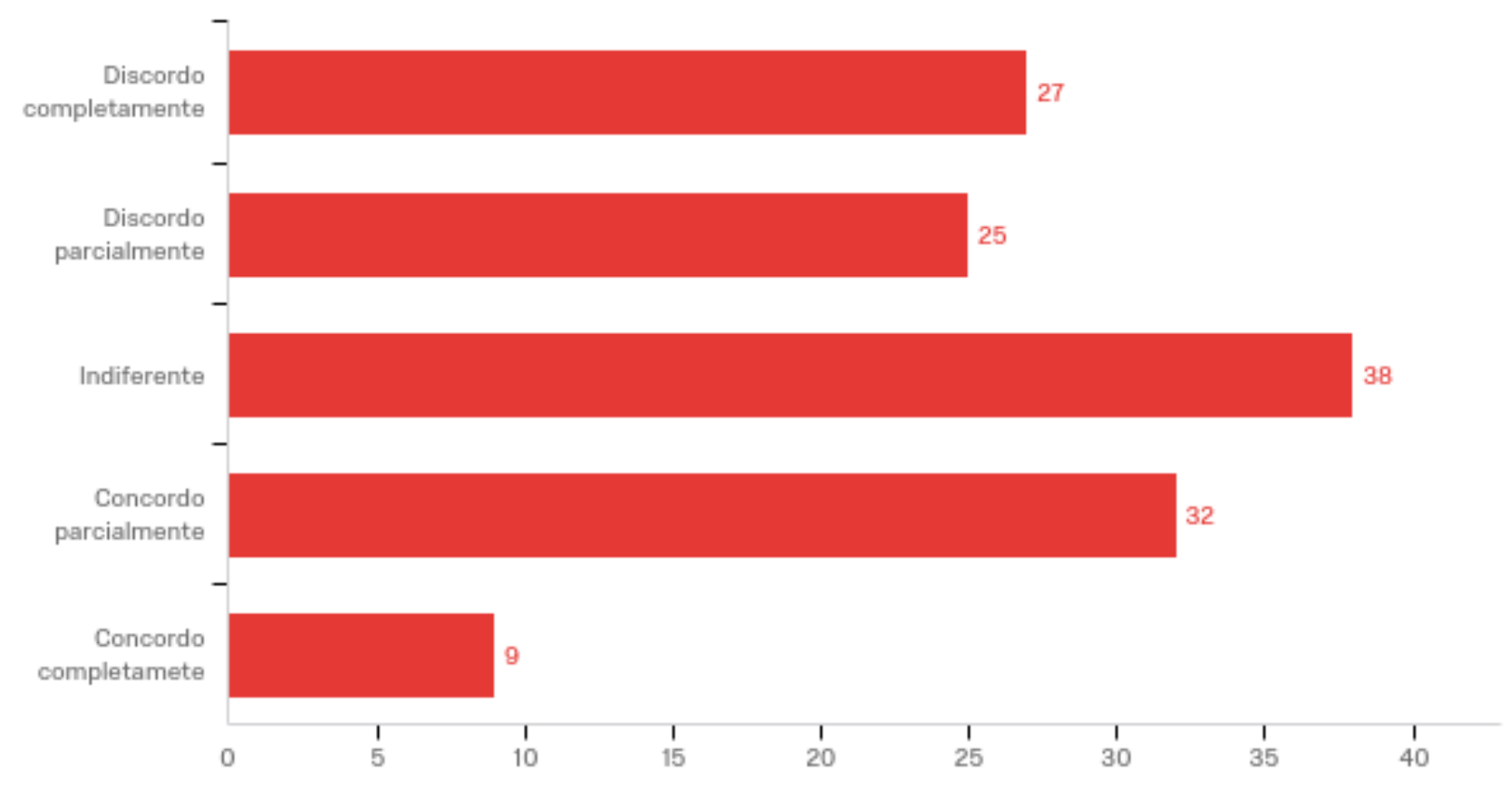

Como é possível ver no gráfico 21 , a peça despertou de forma expressiva a sensação "ambição" nos consumidores, sendo ela ligada a emoção "inveja". Essa sensação representa $22,6 \%$ dos dados coletados. Porém, se desconsiderarmos tal sensação do estudo, as emoções se mostram dispersas, com sensações de todas as outras emoções (felicidade e medo) despertados na mesma peça.

Essa informação apenas confirma que o processo de criação de uma peça que desperte inveja em consumidores de shampoo deve ser revisado, utilizando um maior número de entrevistas qualitativas que busquem entender melhor que fatores despertem a emoção de forma isolada, sem trazer sensações negativas, como aversão e preocupação.

Um ponto de partida para futuras pesquisas qualitativas que visem tal objetivo é levantar o efeito de celebridades frente a propaganda, visto que o uso da mesma obteve alto grau de sensações ligadas a "inveja" na peça de apoio, que somadas a sensações ligadas a "alegria" conseguiram obter efeito positivo na decisão de compra dos consumidores de shampoo. 


\section{Shampoo - Inveja}

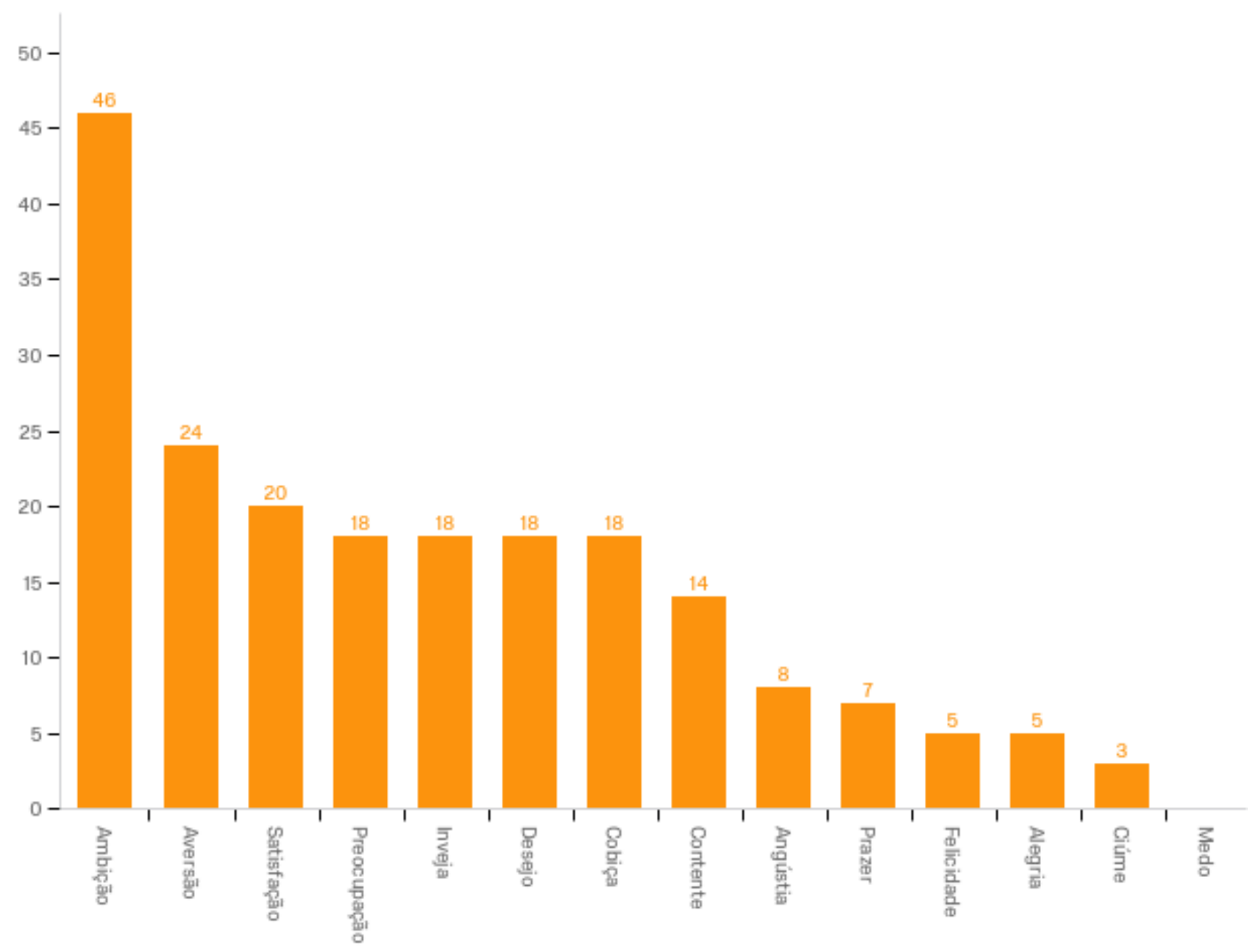

Visando comparar os resultados obtidos pelos insumos que buscavam entender a decisão de compra dos usuários de shampoo, foi utilizada uma análise da escala Likert das perguntas relacionadas ao tema, como feita com as propagandas de universidade. O peso atribuído foi o mesmo, seguindo de -2 (para discordo completamente) a 2 (para concordo completamente).

Como pode-se observar na tabela 5 , a peça que melhor surtiu efeito nos consumidores foi justamente a peça de apoio, que não possuía intuito de causar alguma emoção específica ao ser projetada. Como visto anteriormente, ela despertou sensações ligadas a "inveja" e "felicidade" mesmo sem a intenção. Como dito na análise da mesma, a hipótese para tal resultado é a peça levar 
sensações relacionadas a duas emoções que receberam foram bem avaliadas, juntamente com o uso de uma celebridade.

Seguindo na análise, a peça criada com o intuito de despertar "felicidade" foi a que recebeu a segunda melhor influência na decisão de compra dos usuários, seguida assim pela peça da "inveja" e a peça de "medo".

Tabela 6 - Análise Escala de Likert (Shampoo)

\begin{tabular}{|c|c|c|c|}
\hline \multicolumn{4}{|c|}{ Likert - Shampoo } \\
\hline \multicolumn{2}{|l|}{$\begin{array}{r}\text { Felicidade } \\
\end{array}$} & \multicolumn{2}{|l|}{ Medo } \\
\hline Discordo Completamente & -26 & Discordo Completamente & -128 \\
\hline Discordo Parcialmente & -11 & Discordo Parcialmente & -17 \\
\hline Neutro & 0 & Neutro & 0 \\
\hline Concordo Parcialmente & 53 & Concordo Parcialmente & 20 \\
\hline Concordo Completamente & 30 & Concordo Completamente & 4 \\
\hline Soma & 46 & Soma & -121 \\
\hline \multicolumn{2}{|l|}{ Apoio } & \multicolumn{2}{|l|}{ Inveja } \\
\hline Discordo Completamente & -26 & Discordo Completamente & -54 \\
\hline Discordo Parcialmente & -14 & Discordo Parcialmente & -25 \\
\hline Neutro & 0 & Neutro & 0 \\
\hline Concordo Parcialmente & 57 & Concordo Parcialmente & 32 \\
\hline Concordo Completamente & 42 & Concordo Completamente & 18 \\
\hline Soma & 59 & Soma & -29 \\
\hline
\end{tabular}




\section{Conclusão}

Com o grande número de profissionais de marketing buscando inovações em suas estratégias e novas formas de conseguir se destacar frente ao seu público alvo, é importante que consigamos realizar estudos que permitam uma transferência de conhecimentos multidisciplinares, para que seja absorvido o melhor de cada área e novas soluções sejam obtidas de forma integrada.

O presente estudo buscava testar o uso da metodologia do design emocional em uma estratégia de marketing, apresentando assim seus resultados nos produtos trabalhados. Para isso, respeitou-se o processo criado por Desmet (2002) onde se busca no consumidor insumos a serem usados como meio de despertar certas emoções. Os estudos anteriores, em sua maioria, visavam o uso da metodologia na criação de produtos e foi utilizado o mesmo processo neste trabalho para a criação de peças publicitárias.

Como pudemos observar, as peças que melhor obtiveram aceitação frente ao público que busca uma universidade foram as peças que despertaram inveja e felicidade e se mostraram mais influenciadoras no processo de decisão que a peça de apoio, utilizada hoje no mercado. É possível utilizar essa informação na hora de criar estratégias de marketing voltados para universidade, como para pesquisas que busquem entender que outros fatores levam os consumidores a despertarem sensações ligadas a tais emoções. Tal resultado também é importante para o branding emocional, pois marcas do mercado que utilizem tais emoções podem demonstrar melhor resultado.

Já para o caso das peças criadas para a propaganda de shampoo, a peça de apoio se mostrou a com maior efeito positivo na decisão de compra, sendo observadas sensações nela ligadas a "inveja" e "felicidade". Em seguida, a peça que buscou despertar felicidade se mostrou positiva no efeito sobre o usuário de shampoo. Como dito na análise, as peças que buscavam incitar as emoções identificadas na peça de apoio tiveram alta aceitação, sendo esse o motivo para que tal efeito positivo na mesma. É interessante ver como marcas criam peças sem considerar tais insumos, podendo desconsiderar assim insumos que poderiam ser utilizados em outras campanhas e até mesmo como forma de criar 
estratégias que visam a criação de marca emocional, utilizando insumos do branding emocional.

Pode-se concluir também, que o processo criado por Desmet (2002) se mostrou válido quando usado na criação de peças publicitárias, despertando em sua maioria, as emoções desejadas nos consumidores.

É importante citar que a parte da pesquisa que trouxe insumos ligados ao que influência os consumidores trouxe pontos que se mostraram válidos ao serem utilizados nas peças da pesquisa, o que torna tal parte da pesquisa uma parte importante a ser adicionada no processo do design emocional, buscando assim possíveis pontos de influência no consumidor e usando-os em na pesquisa semiestruturada qualitativa.

\subsection{Sugestões e recomendações para novas pesquisas}

Como dito anteriormente, indica-se uma pesquisa quantitativa que mostre quais os fatores que mais influenciam os consumidores do produto a ser trabalhado. O resultado obtido pode ser utilizado na criação da entrevista semiestruturada.

Outro ponto interessante de ser acrescentado no processo, quando utilizado para uma propaganda, seria o estudo emocional de peças já utilizadas no mercado, pois as mesmas apresentaram sensações despertadas de forma representativa e entendê-las acrescenta ao processo o conhecimento prévio de quais aspectos podem ajudar a projetar a emoção desejada, sendo eles acrescentados a entrevista semiestruturada também.

Sendo assim, o processo ficaria como demonstrado a seguir, na Figura 9: 


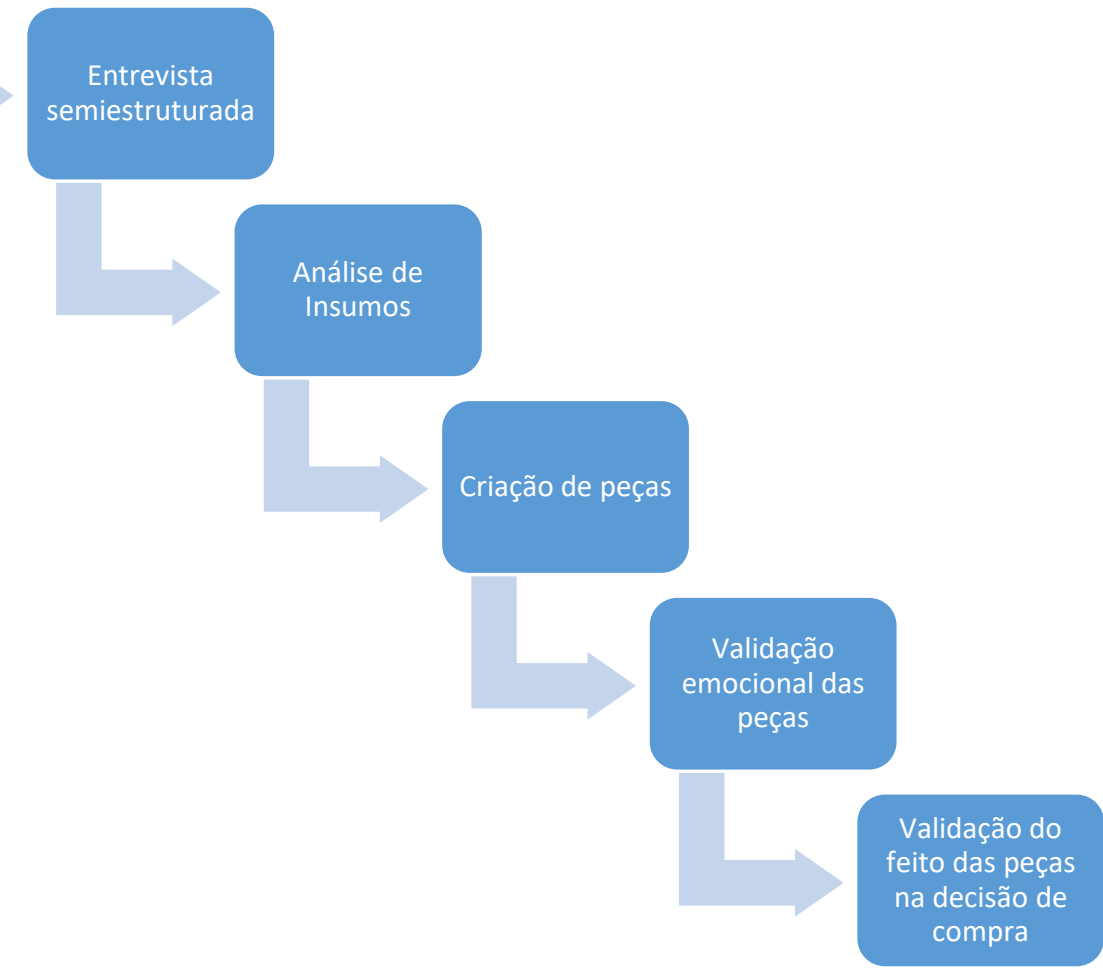

Figura 9 - Sugestão: Processo Design Emocional

Futuros estudos podem ser utilizados como forma de validar o processo sugerido, assim como forma de entender como uma emoção despertada em uma mídia pode atrair sensações atreladas a outras emoções não projetadas (como aconteceu na propaganda de universidade que despertou inveja). Estudos que buscam validar emoções divergentes das apresentadas neste presente trabalho acrescentariam no mapeamento de comportamento de uma emoção para a outra.

São indicados estudos futuros que busquem uma ligação entre o branding emocional e o design emocional, para que traga insumos de como o branding emocional pode afetar uma peça criada sobre uma estratégia de marketing que utilize o design emocional em comparação com uma estratégia que não utilize a metodologia. 
Pesquisas qualitativa que tragam questionamentos de como celebridades utilizadas em propagandas podem influenciar na criação de peças que despertem emoções, visto que o uso da mesma obteve alto grau de sensações ligadas a "inveja" na peça apoio, que somadas a sensações ligadas a "alegria" conseguiram obter efeito positivo na decisão de compra dos consumidores de shampoo.

Como observado no estudo, a emoção "medo" causou resultado negativo em ambos os produtos estudados, sendo válido assim um estudo que busque entender se tal ocorrência é uma questão cultural ou se propagandas que utilizem tal emoção surtem o mesmo efeito em diferentes culturas, assim como se elas possam ou não funcionar ao ser utilizadas em produtos diferentes, como ONGs.

O resultado favorável frente a peça de shampoo de apoio, que obteve sensações de inveja e alegria nos consumidores sugere estudos que busquem entender o uso de celebridades e como elas podem despertar certas emoções.

Por fim, a área exposta no presente trabalho se mostra muito carente de estudos, principalmente no Brasil e seria de grande importância para profissionais de marketing que busquem uma ligação maior com seu consumidor, desde entender o que ele sente frente a sua comunicação ou produto como o que pode influenciá-lo a uma decisão de compra eficaz. 


\section{Referências}

AAKER, D. Relevância de Marca - Como deixar seus concorrentes para trás. Porto Alegre: Bookman, 2011.

DESMET, P. Designing Emotions. 2002. 235 f. Tese (Doutorado em Engenharia de Design Industrial) - Delft University of Technology, DELFT.

GOBÉ, M. Brandjam: o design emocional na humanização de marcas. Rio de Janeiro: Rocco, 2010.

GUYTON, A. C. Fisiologia Humana. 6. ed. Rio de Janeiro: Guanabara Koogan, 1988.

JORDAN, P. 1999. Inclusive design. In: W.S. GREEN; P.W. JORDAN (eds.), Human factors in product design: current practice and future trends. London, Taylor \& Francis, p. 171-181.

CHURCHILL, G. A.; PETER, J. P. Marketing: criando valor para os clientes. 2. ed. São Paulo: Saraiva, 2010.

KOTLER, P.; KELLER, K. L. Administração de marketing. 12. ed. São Paulo: Saraiva, 2010.

LU, Y. Poor Little Fish. 2012. Disponível em: <http://yanlu.com/Poor-Little-Fish> NORMAN, D. Design emocional: Por que adoramos (ou detestamos) os objetos do dia-a-dia. Rio de Janeiro: Rocco, 2004.

PAVLOV, I. Condicioned reflexes. New York: Dover Publications, 1960.

ROSSITER, J.; BELLMAN, S. Emotional branding pays off: how brands meet share of requirements through bonding, companionship, and love. Journal of Advertising Research, v. 52, n. 3, p. 291 - 296, 2012.

RUSSO, B. Shoes, cars and other love stories: Investigating the Experience of Love for Products. Delft: VSSD, 2010.

SINÔNIMOS. 2017. Disponível em: < https://www.sinonimos.com.br >. Acesso em: 30/03/2017 
SOLOMON, M. R. O comportamento do consumidor: consumindo, possuindo e sendo. 9 ed. Porto Alegre: Bookman, 2011.

STEEL, J. A arte do planejamento: verdades, mentiras e propaganda. 4 ed. Rio de Janeiro: Elsevier, 2006.

TONETTO, L.; COSTA, F. Design emocional: conceitos, abordagens e perspectivas de pesquisa. Strategic Design Research Hournal, v.4, n. 3, p. 132 $-140,2011$.

VIEIRA, S. Raciocínio criativo na publicidade. 5 ed. São Paulo: WMF Martins Fontes, 2007. 


\title{
Anexo 1 - Entrevista Qualitativa 1
}

\author{
Nome: Alessandra Baiocchi
}

Profissão: Professora e Supervisora na Pontifícia Universidade Católica do Rio de Janeiro (PUC-Rio).

P: Gostaria de entender o que você sabe sobre a divulgação da faculdade PUC.

A: Eu vejo a divulgação da PUC em diversos níveis. Eu já ouvi a PUC como instituição no rádio, PUC como CCE já vi peças em ônibus, PUC Administração em diversos folhetos. Eu vejo também muitas campanhas com as escolas através do PIUES, dos eventos como "PUC por um dia". Todo evento que a gente faz, de certa forma, tem uma divulgação do serviço da universidade e acho que principalmente através de boca a boca, o aluno falando...e também mídias como revistas, como agora ganhamos prêmios de melhores faculdades. Tudo isso é uma forma de você divulgar a universidade.

P: Entendi. E...como você acredita que PUC se posiciona frente as universidades em suas comunicações?

A: Eu acredito que ela sempre se posiciona como a melhor universidade privada do Brasil. Isso que ficou muito marcado, não sei se foi por conta do último título, né? Mas...isso. A melhor universidade privada do país.

P: Então, seria a qualidade?

A: Qualidade. Qualidade e tradição, né?

P: Tá. Eu sei que você já passou pela PUC também (ruído) e eu queria entender porque você escolheu a PUC?

A: Puxa! Mas...é absolutamente pessoal isso, né? Bom, meu pai e minha mãe se conheceram cantando no coral da PUC. Meu pai estudou engenharia aqui, minha mãe estudou letras aqui. É...desde pequenininha, eu morava aqui perto, meu pai me trazia pra passear na PUC. (ruído) E me trazia pro pilotis e dizia "eu estudo aqui" e me mostrava o prédio de engenharia. É...bom, na época do vestibular...é...a PUC é um dos primeiros vestibulares e eu era da época do 
Cesgranrio, né? Você faz Cesgranrio e...eram três vestibulares: um pras federais, um é o Cesgranrio que era pra todo mundo e um pra PUC. A PUC era o primeiro. Quando eu fiz o vestibular da PUC, é...eu passei em segundo lugar, ganhei uma bolsa integral e aí eu não fiz pra mais nenhuma. (ruído) Eu já morava aqui do lado, já passeava aqui desde pequena...

P: Já exista essa conexão, então...

A: Já existiu, eu era...eu sou a filha da PUC, né? Literalmente. E assim, nem fiz vestibular pras outras escolas.

P: Entendi. Então foi natural...

A: Foi natural.

P: Tá. Agora vamos para as perguntas mais abertas, que eu te falei. O que você acha que...dá medo em um universitário na hora de escolher a faculdade?

A: O que dá medo no universitário...Eu acho que dá medo ele escolher o curso que ele não vai gostar, de estar escolhendo errado. Eu acredito que dê medo ele sentir que tá perdendo o seu tempo por ter escolhido errado. Eu acredito que dê medo dele escolher um curso que não vai ter empregabilidade no final. Eu acho que dá medo, é...ele gastar um dinheiro sem ter um retorno...se ele fez a escolha errada.

P: Ok. É...e felicidade? O que você acha que um aluno...o que pode fazer um aluno ter um sentimento de felicidade por uma faculdade? Dizer "eu me sinto feliz nessa faculdade" ou "eu me sentiria feliz nessa faculdade"?

A: Quando ele se sente...sentisse como se ele pertencesse aquele espaço, né? É...acho que felicidade é você se sentir bem aonde você tá, fazendo o que você faz, com os amigos que você tem. Eu acho que é isso.

P: Ok...E o último seria inveja. O que causaria inveja em uma pessoa...por exemplo, você é de uma faculdade diferente da minha, o que te causaria inveja pela minha faculdade?

A: O que causaria inveja...é...eu acho que eu ver que a sua faculdade é melhor colocada do que a minha. É...te dá mais oportunidades, né? Uma universidade 
que te dê mais oportunidades, no sentido de aprendizado, intercâmbio, trabalho, melhores amigos, mais segura...eu acho que isso pode causar inveja.

P: Entendi, tá bom. Obrigado! É isso.

A: Obrigada! 


\section{Anexo 2 - Entrevista Qualitativa 2}

Nome: Tatiana de Oliveira Angeli

Idade: 36 anos

Profissão: Publicitária no IAG-PUCRIO

P: Primeiro eu queria entender um pouco como é que é feita a divulgação da PUC aqui. Como é que vocês fazem...no caso o IAG, né? Que é onde você trabalha.

T: É...a divulgação você diz de que exatamente?

P: Da própria faculdade pra fora. Eventos ou peças...

T: Tá. A gente trabalha com mídia online, né? Então fazemos anúncios em Google Patrocinado, Facebook...né? Isso eu tô falando no âmbito IAG, tá? (ruído) E...a gente faz eventos aqui internamente. Como palestras, cursos, divulgação por e-mail marketing, né? Então a gente tem algumas veias que saem para divulgação de um determinado evento. Então a gente usa outros meios para divulgar o que a gente tem, né? Então a gente divulga cursos, eventos...basicamente isso.

P: Entendi. Aqui, o IAG, ele tem alguma ligação com alguma outra parte da faculdade? Em questão de divulgação...ou não? Por exemplo, a Mostra PUC, como é que vocês entram na Mostra PUC? É uma parceria?

T: Não, é separado. Mas a gente já participou da Mostra PUC com stand representando o IAG, escola de negócios. E aí a gente coloca lá nossos cursos, né? O que a gente propõe dentro da universidade, mas a gente não faz ligação direta com eles. Mas a gente participa de alguma forma, participa com stand representando a escola de negócios.

P: Entendi. Tá, e como é que a escola de negócios se posiciona frente as outras escolas de negócio? 
T: Olha, frente as demais, a gente se posiciona no gancho da PUC mesmo, né? Porque a gente é a escola de negócios da PUC Rio. Então a marca PUC Rio é muito forte, né? Então a gente se posiciona com essa excelência acadêmica da universidade, por ser um campus universitário. Então o nosso posicionamento é PUC Rio. A gente é só a escola de negócios da PUC Rio.

P: Então no caso a PUC, se coloca pela excelência...

T: Isso, pela excelência acadêmica

P: Entendi. Então...agora...como a minha pesquisa envolve muito diversos tipos de emoções, eu vou fazer umas perguntas abertas sobre emoção e não tem resposta certa, tá? Eu só quero entender o que você entende dessas emoções.

T: Tá bom, vamos lá! Mas aí eu falo como...

P: Como você Tatiana.

T: Tá legal.

P: Porque é importante entender como a pessoa que trabalha nas peças de divulgação, ela entende essas emoções, entendeu?

T: Certo, entendi.

P: Tá. O primeiro é...o que você acha que daria medo para um aluno na hora de entrar em uma faculdade, escolher uma faculdade?

T: De escolher uma faculdade....acho que....a faculdade ou o curso?

P: Tanto faz...

T: Acho que a certeza de...hoje em dia a certeza de que aquilo é uma escolha certa para ele ser bem sucedido. Acho que tem muito isso, assim...A escolha do curso certo, a escolha da faculdade...é....porque você tá escolhendo o seu futuro, né? E é um futuro cada vez mais incerto, né? Então, acredito que seja esse o grande questionamento...é, das pessoas que estão aí para entrar dentro de uma faculdade. Não saber se é o melhor caminho...

P: Bacana...a segunda é...o que traz felicidade para um aluno quando ele pensa numa faculdade? O que você acha que traria felicidade? Eu tenho felicidade pela minha faculdade porque... 
T: Eu tenho felicidade pela minha faculdade porque...é...acho que é uma série de coisas, mas uma é você estar num lugar que realmente você consiga aprender alguma coisa. Você poder debater, né? Você poder estar junto com pessoas e pensantes...e discutir sobre um assunto, né? Acho que o que pode te dar felicidade numa universidade é exatamente essa troca com pessoas...e eu digo troca com professores e com alunos, né? De ter esse relacionamento...acho também que te faz feliz se você tem um envolvimento com a marca, né? Porque eu sinto assim...e aí é um sentimento que eu vejo nas redes sociais até...que as pessoas, quando a gente fala PUC, muitas pessoas tem um sentimento...assim, nossa eu estudei lá e sei como é lá, né? Então quando a pessoa vive a PUC Rio no seu todo, acho que esse campus também é uma coisa que te traz felicidade. Então você tem uma...você remete a uma questão de vivência mesmo, né? Então assim...e também tem aquela questão de que assim, poxa foram quatro anos que eu passei aqui que...eu, eu por exemplo, eu estudei aqui também. Então quando eu falo PUC, pra mim é muito envolvente, até porque eu também lembro que eu tava estudando, né? Então acho que é isso...e aí eu entro e eu como aluna, trabalhando...eu como diversos personagens e eu posso responder por todos eles.

P: Com certeza! É...e o último, o que você acha que traria inveja para um aluno? Em questão de universidade...por exemplo, eu tenho uma faculdade e você tem outra, o que faria você ter inveja da minha faculdade?

T: Olha...eu acho que inveja da faculdade talvez seja um dos pontos...é...que algumas empresas tem uma preferência, entre aspas, por alunos de algumas universidades, né? Então talvez isso cause uma certa inveja, né? Em alguns processos seletivos...é...assim, na minha época e eu acho que isso ainda em burburihos...isso ainda acontece um pouco, algumas empresas grandes tem uma preferência, né? Por algumas universidades...não vou citar, mas existe isso. Isso por causar uma certa inveja. Acho que inveja também quando você vê que as universidades estão melhores posicionadas em rankings, né? Porque como você vai fazer alguma métrica, né? Mas de repente você vê...nossa a universidade $X, Y$ atingiu pontos no ranking tal e...enfim, aí você olha...nossa, a minha não está lá, né? Então...acho que isso. E dentro esfera mais acadêmica...talvez quando você vê na televisão alguns economistas e algumas 
pessoas de...de alguma ciência específica dando entrevistas, né? Então você vê no Jornal Nacional, você vê no Fantástico, você vê na Band News...especialistas, e lá tá "Economista e Professor da universidade tal". Acho que isso também pode...porque são quase sempre as mesmas universidades que emprestam os seus pensantes pra falar nesses meios de comunicação. Então, eu creio que isso também possa dar uma invejinha...

P: Entendi. É isso! Obrigado! 


\title{
Anexo 3 - Entrevista Qualitativa 3
}

\author{
Nome: Luana Barbosa
}

Idade: 30 anos

Profissão: Estudante de Design Gráfico

P: Você estuda Design Gráfico, né? Aonde você estuda?

L: Eu estudo na UniCarioca, estou no quinto período de Design.

P: Porque que você escolheu a UniCarioca?

L: Na verdade...eu ganhei uma bolsa, né? E aí...pelo ProUni. E aí eu já tinha feito publicidade na UniCarioca do Méier e quando fiz o ProUni de novo...decidi fazer design e escolhi pela UniCarioca porque já tinha estudado antes lá e gostei, gostei do método, gostava dos professores, gostava do lugar, gostava de tudo...e é uma faculdade bem...ah, não sei explicar, eu gosto da Unicarioca. Eu não tenho nada contra não.

P: Entendi... você disse que começou publicidade lá, né? Porque você escolheu a Unicarioca quando você foi fazer publicidade?

L: Na época, quando eu fiz publicidade, era perto do meu trabalho. Lá no Méier...era próximo e eu ia a pé. Eu saia do meu trabalho e era o mais próximo, era só uma rua. Aí depois, eu tranquei a faculdade de publicidade, fiz até o quarto período, tranquei, e agora...eu retornei. Depois de casada, filhos, eu retornei fazendo design gráfico. Mas para a UniCarioca do Rio Comprido.

P: Entendi...você sabe como a faculdade se divulga? Se eles usam cartazes ou coisas assim?

L: Usa, usam cartazes, outdoor, anúncio de rádio...é, tem o site deles, tem...assim, tem a questão também que você indica um amigo e tem desconto, existem várias coisas de marketing lá dentro. Eles tem na verdade, uma agência de marketing dentro da faculdade. É uma agência escola, entendeu? 
P: Entendi...Deixa eu te perguntar, você sabe como eles se posicionam? Se é pela qualidade, pelo preço...como é que eles se colocam nesses cartazes?

L: Atualmente eles estão se posicionando pela qualidade, porque tem alguns cursos que ficaram em primeiro lugar pelo MEC. É...através do ENADE eu acho, e alguns cursos ficaram em primeiro lugar. Então já tem cursos que estão há três anos consecutivos em primeiro lugar. Então, eles se prevalecem em cima disso, né? Excelência...

P: Entendi. Deixa eu te explicar...a minha pesquisa, ela envolve certos tipos de emoção. Então eu vou te fazer umas perguntas sobre as emoções que eu estou trabalhando e assim, não tem resposta certa. Eu vou perguntar e eu quero que você me diga o que passa na sua cabeça mesmo, o que você acha dessa emoção.

L: Tá...

P: A primeira é...o que você acha que dá medo pra um aluno quando ele vai escolher a faculdade?

L: Caramba, não tá passando nada na minha cabeça, tá passando um filme na minha cabeça agora...cara, o que dá medo, a insegurança que dá é...não estar escolhendo o seu curso certo. Entendeu? Se você tá fazendo a coisa certa, se você escolheu o curso certo...eu estou falando da minha experiência. E aí...no meio do percurso tive que largar, porque não era aquilo...entendeu? E aí tive que fazer outra.

P: Tá, entendi. E o que você acha que traria felicidade? Que ele sentiria felicidade pela faculdade que ele está escolhendo, no caso.

L: Entrando...é uma felicidade imensa. Porque por exemplo, eu entrei com uma bolsa de $100 \%$...eu não estava esperando, estava esperando no máximo 50\%, $60 \%$...entendeu?

P: Entendi...se você fosse dizer, por exemplo, eu sou feliz porque eu escolhi a faculdade tal...o que você diria?

L: É...na verdade, eu falo que foi a minha segunda chance, né? A minha primeira chance eu joguei fora e essa é a segunda chance que a minha vida deu, 
entendeu? E coincidentemente caiu em uma faculdade que eu gosto, que é a Unicarioca, entendeu? Porque quando eu fiz a inscrição lá no ProUni, foi minha primeira opção, a UniCarioca...Eu gosto da faculdade, eu não tenho nada contra. Tem pessoas que falam coisas ruim da faculdade, mas todas elas tem prós e contras, entendeu? O método de lá é bom...os professores trazendo novidades, coisas novas...e a gente trocando experiência com eles.

P: Tá, entendi...Bom, agora a última emoção é inveja. O que você acha que causaria inveja em um aluno que, por exemplo, eu sou de outra faculdade, o que faria você ter inveja da minha faculdade?

L: Cara...se for de uma faculdade de uma excelência superior. No caso não sei se é inveja...eu considero mérito, sabe? Porque tem pessoas que tem um mérito, passaram, e conseguiram entrar naquela instituição. Tem pessoas que são invejosas sim...poxa, fulano conseguiu e eu não consegui. Eu já penso que eu tive a oportunidade e não obtive o êxito. Acho que inveja é uma coisa tão ruim...não é válido ter essa energia.

P: Entendi...mas e essas pessoas que você falou, que dizem ter inveja de outras que possuam outras faculdades. Elas dizer o que das outras faculdade?

L: Eu acho que...elas não falam da faculdade, elas falam das pessoas que passaram. Ahhh, fulano passou porque estudou em escola particular, fez pré vestibular e eu não tive como porque...é...eu trabalhava e estudava...E assim, eu acho que esse tipo de pessoa é mesquinha, porque nada a ver...tem pessoas que trabalham e estudam e conseguem passar em uma pública. Eu acho que é questão de mérito mesmo.

P: Então tá bom, é isso. Obrigado! 


\title{
Anexo 4 - Entrevista Qualitativa 4
}

\author{
Nome: Anderson Napoleão
}

Idade: 33 anos

Profissão: Estudante de Mestrado em Ciências Computacionais

P: Bom, como eu disse, essa entrevista vai ser feita focada em um serviço, que no caso é universidade...e as perguntas vão em cima disso. No caso, você estuda em que universidade?

A: Na UERJ. Estou fazendo mestrado de Ciências Computacionais.

P: Tá, eu queria entender um pouco se você sabe como a UERJ se divulga. Se você já viu algum banner, algum site, alguma coisa do tipo da UERJ se divulgando para o mercado?

A: Eu vejo...site e o facebook também. Acho que só (risos). Acho que a maior propaganda é o vestibular mesmo.

P: Entendi. E você sabe como a UERJ se posiciona frente as outras universidades?

A: Hum.. pela qualidade do ensino. Acho que pelo fato de ser estadual também.

P: Eu queria entender como funcionou para você entrar na UERJ. Eu sei que é pública mas você tinha outras escolhas também na teoria, no vestibular.

A: Então, no ano que eu fiz o vestibular, eu acabei fazendo pra UERJ e UFRJ e...foi naquela de a que eu passasse, seria. Não foi uma escolha de ter que ir para a UERJ...Aí calhou de eu ter passado para UERJ. E aí eu já conhecia a estrutura um pouco, por provas que eu já tinha feito lá no prédio e...aí eu fui para UERJ e gostei bastante de lá.

P: Entendi. E agora, são as perguntas mais abertas, são perguntas sobre emoções específicas. Eu queria entender o que você acha que pode causar medo em um aluno, na hora de escolher uma faculdade? 
A: Deixa eu pensar aqui...Medo na hora de escolher...Talvez acho que, o tamanho, a dimensão...Talvez acho que possa dar medo de ficar perdido. Assim, no meu caso, a UERJ é uma faculdade muito grande e eu sempre escolho em escola pequena, então tinha medo de estar indo para um lugar que é muito maior do que você está acostumado a frequentar. Me sentir perdido. Inclusive na época em que eu entrei, não tinha muito a recepção para os alunos como tem hoje, então fui meio jogado na faculdade.

P: Legal...e o que você acha que poderia trazer felicidade, para um aluno? Assim, ah eu me sinto muito feliz de estar na UERJ...porque?

A: Ah, eu acho que...pela qualidade da universidade. De estar em uma universidade que é reconhecida. E também por, investimento nos alunos, projetos de pesquisa, essas coisas assim. Você estar realmente tendo alguma ocupação, um desenvolvimento bom e não só estudando. Então acho que é muito bom para despertar momento de felicidade.

P: E o que você acha que traria inveja? Por exemplo, eu tenho inveja da sua faculdade porque...?

A: Acho que até por isso, por ter um diferencial de você não só estudar, mas também...aplicar o conhecimento e ter um retorno.

$P$ : Então se você visse que uma faculdade oferece um retorno melhor você ficaria com inveja..
A: Isso (risos)
$\mathrm{P}$ : É isso, obrigado! 


\section{Anexo 5 - Entrevista Qualitativa 5}

Nome: Ana Maria Kossatz de Bêrredo

Idade: 63 anos

Profissão: Designer de Jóias e Empresária

P: Bom, essa pesquisa é sobre um produto específico. É sobre shampoo. Você é usuária de shampoo?

A: Sou usuária de shampoo.

P: É... você tem alguma marca específica que você compra?

A: Não, adoro experimentar!

P: Legal, legal...como é que funciona isso? Como você escolhe?

A: Porque eu acho que o cabelo vicia...você compra um...mas como eu compro vários, eu sempre esqueço o que foi bom, né? Também tem isso...mas eu acho que ele fica cansado. Quantos mais novos eu comprar, eu acho que ele fica mais contente.

P: Entendi. E como funciona essa escolha? Você vai no mercado...como você escolhe?

A: O...visual, é importante. Gosto que seja líquido, não pode ser muito cremoso, porque dizem que fica oleoso o cabelo, dá caspa, sei lá. Então, transparente...mas nem sempre tem. É...procuro sem sal, porque também me disseram que é bom. É sempre no que me disseram...E compro um, se der certo eu compro outro, mas de outra cor. Sempre vario, ah...as vezes a substância é camomila, daí eu compro outro...macadâmia.

P: Entendi...e aí, por exemplo, você chegou e tem todos que você já comprou lá. Você tenta comprar um que você já usou faz muito tempo?

A: Tento, tento....mas eu não sou tão metódica. Eu digo...ah, esse aqui eu acho que era bom. 
P: Então, não tem marca. Você não vai pela marca...Você experimenta marcar diferentes...

A: É lógico que se eu estiver lá fora e...ver que tem uma marca que eu conheça...um La Roche...um shampoo La Roche...eu vou dar uma atenção especial...E se estou aqui também, eu vou dar uma atenção.

P: Mas então, qual marcas você daria uma atenção maior?

A: Essas conhecidas...mas também são muito caras...então eu fico mais nas naturebas, sem sal e...sem muita química.

P: Agora as perguntas vão ser bem específicar em certos tipos de emoções. Porque o meu trabalho ele mexe com certo tipo de emoções. Então eu vou te fazer perguntas abertas sobre certos tipos de emoções, pode viajar, pode falar o que você imaginar dessas emoções...Eu queria saber o que te faria medo de usar um shampoo?

A: Ter que usar esse shampoo inteiro. la me dá raiva...tenho medo de ficar com raiva de dar um troço lá empatado.

P: Tem raiva de dar alguma coisa ruim com aquele shampoo e mesmo assim você tem que usar ele até o final, é isso?

A: É...ou então, errei...é uma frustração. Ih, errei.

P: Entendi. O que seria o terror pro seu cabelo? Que um shampoo poderia fazer com seu cabelo...

A: Deixar ele muito seco...normalmente eu passo adiante. Não deu certo comigo, vai dar certo com alguém.

P: Entendi. Ah, legal...interessante. É...o que faria você sentir felicidade por um shampoo?

A: Ai...deixar lindo, maravilhoso, brilhante, esvoaçante.

P: É..e o que faria você ter inveja do cabelo de outra pessoa?

A: Ah...inveja... eu não tenho inveja não. É do brilho, corte...normalmente são os compridos e de jovens. 
P: Não tem aquela pessoa que você olharia e falaria "nossa acho que vou perguntar que shampoo ela está usando"?

A: Não, isso eu não faço. Primeiro porque o que dá certo para um, não dá certo para outro. As vezes a gente compra um shampoo lá fora, lindo, maravilhoso e não dá certo no nosso cabelo...então, é questão de arriscar mesmo.

P: Arriscar...legal. Muito obrigado! 


\section{Anexo 6 - Pesquisa Qualitativa 6}

Nome: Natanael Almeida

Idade: 29 anos

Profissão: Assistente Administrativo

$\mathrm{P}$ : Bom, primeiramente, eu queria saber se você é usuário de shampoo?

N: Não, usuário não...eu uso, porém não é aquela coisa que tem que ter sempre no meu banheiro.

P: Entendi, você usa ocasionalmente.

N: Isso, ocasionamente. Não sou aquela coisa "ah, tem que ter, está faltando".

P: Entendi...é, você alguma ligação com alguma marca específica?

N: Não, geralmente eu uso o Dove, Tressemé e Pantene.

P: E porque você usa eles?

N: Costume mesmo...não aquilo de essa marca é boa, questão de midia não. Eu tenho uma mania muito feia, eu vejo que a marca é mais cara, eu compro. Porque pra mim tudo que é caro é bom, entendeu?

P: Faz sentido...então, o que tiver mais caro você compra...até entre o Dove, Tressemé e Pantene?

N: Isso.

P: Então, agora eu vou fazer umas perguntar abertas sobre diversos tipos de emoções e não tem resposta certa, tá? Você responde o que vem na sua cabeça. O que faria você ter medo de comprar um shampoo?

$\mathrm{N}$ : Medo de comprar um shampoo...seria nossa, eu usar um shampoo e o shampoo dar caspa na minha cabeça. Nossa, eu teria um infarto. la parar de usar na hora, ia abrir o SAC e berrar.

$P$ : Entendi, e o que faria você ter inveja do shampoo de outra pessoa? 
N: Inveja do shampoo? (risos)

$P:$ É...ou do cabelo, tanto faz...

N: Ah, do cabelo. Por exemplo, você tem um cabelo lisinho e eu não tenho um cabelo lisinho...mas não inveja. De shampoo, muito menos.

P: Você não olharia para o cabelo da pessoa e pensaria "nossa qual o shampoo será que ele deve usar"?

N: Não, não...não tenho essas frescuras não.

P: Entendi...e a última seria, o que faria você sentir felicidade pelo shampoo que você está usando?

$\mathrm{N}$ : Ah, então...eu ter um cabelo cheiroso, brilhoso...coisa que não é o que acontece, né? $\mathrm{Na}$ verdade, igual eles falam...ah o shampoo vai trazer fortalecimento, isso, isso, isso...na verdade não traz. Eu sou estudante, então sei que isso é tudo mentira.

$P$ : Entendi...então é isso. Obrigado! 


\section{Anexo 7 - Entrevista Qualitativa 7}

Nome: C.G

Idade: 26 anos

Profissão: Estagiária de Marketing da Marca X

P: Bom, primeira pergunta. Eu queria entender um pouco como funciona a divulgação da Marca X, do shampoo no caso.

C: Tá, mas...você está falando de que tipo de mídias:

$\mathrm{P}$ : Isso

C: Tá. Tem duas frentes importantes. Tem a mídia digital, que hoje em dia concentra grande parte do nosso investimento, porque apresenta o maior retorno, como muitas empresas na verdade estão identificando isso. Então a gente tem um investimento grande em mídia digital, que é o Facebook, Youtube com ads e conteúdo, no Google a gente faz a partir de busca, então a gente investe em compra de palavras que leva pro nosso site da Marca $X$. É...no Instagram a gente não faz investimento porque agora no Instagram é uma marca única internacional, então...como é um Instagram no mundo todo, acaba que tem alguns posts da Marca $X$, mas não é muito o foco. É...aí tem essa parte, que concentra grande parte do investimento da marca e a outra parte, chamamos de mídia offline, que abrange tudo que não é digital. Por exemplo, agora a gente fez

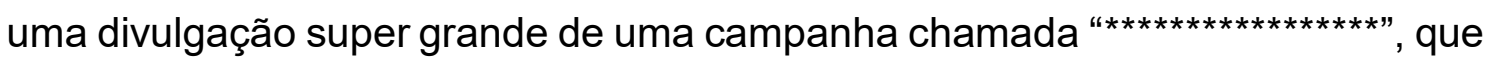
falava dos pilares da Marca X, com os cinco maiores pilares de cabelo, e aí foi uma campanha quase totalmente offline, foi de out of home, que são aquelas propagandas que tem no metrô, por exemplo. Então, a gente investiu, foi uma campanha super grande tal, foi boa, tivemos bastante retorno...então, a gente trabalha nessas duas frentes. E aí...A segunda parte que funciona também como mídia offline, é a televisão, que são os comerciais de televisão. Então a gente ainda faz esse tipo de investimento, mas muito menos que antigamente, porque tem alto custo e o retorno vem diminuindo cada vez mais. Isso eu estou considerando o que fazemos normalmente, porque ainda tem o material de PDV, 
que é o que você vê nas lojas, nas farmácias, que são aqueles materiais que...tipo cartaz, toten e tal.

P: Tá...a segunda pergunta é como é que a Marca X se posiciona em frente aos concorrentes?

C: Tá, isso é bem abrangente. Tipo, em relação ao o que, por exemplo?

P: Ah...a Marca Y por exemplo.

C: É, Marca X e Marca Y são concorrentes e principais marcas de cabelo aqui no Brasil, mas é o principal concorrente porque tem o mesmo público alvo. Mas o maior player nesse mercado de cabelo no Brasil é Marca Z, há muitos anos eles tem uma fatia super grande de mercado, então são tipo monstros. Então é engraçado porque não é uma briga que a Marca $X$ tem, porque é um público alvo muito diferente, é uma briga de preço muito grande. Então, Marca Y é o principal concorrente e a estratégia, a guerra de mercado é no ponto de venda, sabe? Então é muito menos...óbvio que a comunicação tem uma parte muito importante, mas é muito mais a guerra no ponto de vendas, de quem está em todos os pontos comerciais, quem está em todas farmácias, quem está melhor distribuido no Brasil, do que quem está mais tempo na Globo.

P: Entendi...tem muito mais ligação com a praça, no caso.

C: Sim, muito mais a ver com a praça assim, em questão de distribuição mesmo. Porque, o que acontece, o Brasil, diferente de vários outros lugares, é cheio de mini comércios, então é muito dificil chegar nesses mini lugares. Os grandes, todo mundo tá, mas...os pequenos não. Então, ganha briga quem consegue jogar um volume grande em mercados grandes, tipo Guanabara, Wallmart, Carrefour e quem consegue chegar nesses pequenos. Então, na verdade, a guerra desse mercado está muito mais aí. O que as marcas fazem é muito mais analisar isso, o quanto de mercado você tem, o share de mercado, e aonde você não tá que o seu concorrente está, que é onde você precisa estar.

$P$ : E na comunicação, o que difere a comunicação, no caso, da Marca $Y$ para Marca X?

C: Bom...é...a comunicação de Marca Y é uma comunicação bem diferente. Ela tem uma comunicação única, fala muito de Marca $Y$, não vende muito a franquia. 
A Marca $Y$ é Marca $Y$, tem franquias que são mais importantes, tipo Hidratação, mas eles vendem Marca $Y$ em uma comunicação única. E antes, eles tinham só uma porta voz, que era $a^{* * * * * *}$. Agora eles abriram, tem $a^{* * * * * *}$, essas meninas. Então eles estão abrindo um pouco mais essa comunicação, mas eles continuam reforçando em uma marca que é Marca Y. Isso é totalmente cultural da empresa, que tem sempre essa tradição de comunicar a marca. Já a Marca $X$ é completamente o oposto disso. Marca $X$ comunica cada franquia. Marca $X$ tem um comercial só para $\mathrm{a}^{* * \star * \star}$, que é a franquia da ${ }^{* * * *}$, uma franquia para falar de ${ }^{* * * * *}$, que é $o^{* * * *} d a^{* * * *}$. Então, a gente comunica de forma separado, muito menos a marca Marca $X$ e muito mais qual é a franquia. Você enxerga Marca $X$ muito mais pelas cores, pelas porta vozes, do que como Marca $X$ marca. É uma estratégia completamente diferente da Marca Y.

P: Entendi. Agora, essa parte da entrevista é muito mais você como consumidora. Você é usuária de shampoo?

C: Sim.

P: Eu queria entender, para você como funciona escolher um shampoo?

C: Tá...normalmente eu vejo a necessidade do meu cabelo. Então, se eu vejo que o meu cabelo está ressecado, eu procuro no mercado e vejo shampoos que atendem a essa necessidade. Tentando ser mais imparcial, eu procuro o shampoo que atenda essa necessidade, se essa necessidade é muito importante para mim, eu acabo optando por escolher um produto mais caro, porque acho que vou ter um retorno melhor.

P: Você tem uma marca de preferência? Não precisa dizer o nome...

C: Bom, agora, faz uns dois anos...eu só uso Marca X (risos) Assim, óbvio por eu trabalhar lá também, mas antes eu usava bastante a marca John Frieda, que nem é uma marca daqui, mas enfim, o meu cabelo ficava incrível, é americana. Hoje em dia eu uso Marca X, mas eu uso John Frieda também, para falar a verdade, porque é uma marca que funciona muito no meu cabelo.

P: Então como era a sua relação com essa outra marca? Era porque trazia resultado, no caso? 
C: Sim, trazia um resultado assim, instantâneo. O meu cabelo não precisa nem estar ruim, ficava sempre maravilhoso.

P: Você podia confiar, no caso...

C: Sim. Confiança mas não fidelidade, porque além de ser um produto que não tinha no Brasil...é, era de difícil acesso.

P: Agora eu vou fazer perguntas bem específicas para o tema da monografia e elas são bem abertas. Eu quero saber mesmo o que você entende, a primeira coisa que vem na sua cabeça. Entendeu?

C: Tá bom, beleza!

P: O que você acha que faria você ter medo na hora de escolher um shampoo ou de usar um shampoo?

C: É..bom, acho que...teria medo de estragar o cabelo. Eu já tive uma experiência ruim, assim, é...quando eu tava viajando todo mundo falava muito de um shampoo e eu tive uma experiência péssima. Então eu comprei uma grande expectativa e foi horrível pro meu cabelo, deixou meu cabelo horrível. Então, o meu medo é esse, estragar meu cabelo, deixar meu cabelo ruim e depois eu ter que procurar um produto muito melhor, um produto bem mais caro para deixar ele bom novamente.

P: Entendi. O que seria um cabelo estragado para você?

C: Cara, cabelo estragado para mim...meu cabelo é liso natural, só que ele é muito cheio, então é um cabelo que dá volume e eu não gosto de volume. Então, por exemplo, um cabelo estragado para mim é quando um cabelo que é cheio fica ressecado...então quando meu cabelo fica cheio e ressaco, para mim, fica estragado.

P: O que faria você ter inveja do shampoo de outra pessoa?

C: Ai...acho que o resultado. Tipo, brilho. Brilho é um resultado que é super forte quando eu vejo o cabelo da pessoa super brilhoso. O cheiro, acho que o cheiro é tipo...quando você sente que o cheiro vem do cabelo daquela pessoa, pra mim é super expressivo. E eu já passei essa situação, de olhar pro cabelo de uma pessoa e falar "Caraca! O que a pessoa colocou no cabelo? Não é possível!". E 
era até um shampoo da Victoria's Secret, o que eu não esperava. Era um cheiro e um brilho incrível. Então, foi um momento em que eu fiquei com inveja branca. (risos)

P: O que faria você ter felicidade de comprar um shampoo ou usando um shampoo, no caso?

C: Eu acho que...pra mim é o resultado. Eu fico feliz quando eu uso um produto e eu já sei que vai me dar resultado. Então, quando eu...não é nem o momento de uso, as vezes o produto pode até não ser incrível durante a lavagem, mas quando eu sei que vai dar um resultado muito bom, eu já fico feliz antes de usar. E eu já uso o shampoo em um momento especial...tipo, quando eu quero que o cabelo fique bom naquele dia, eu não vou usar o shampoo errado, eu vou usar o shampoo que eu sei que dá um resultado. $E$ isso me traz um sentimento de tipo, uma felicidade de estar usando aquele shampoo...de saber que é certo.

$\mathrm{P}$ : É isso! Muito obrigado! 


\section{Anexo 8 - Entrevista Qualitativa 8}

Nome: Bianca Ribeiro

Idade: 23 anos

Ocupação: Jornalista

P: Essa pesquisa é sobre shampoo, então a primeira pergunta que eu tenho é se você é usuária do produto.

B: Sim, eu uso shampoo pelo menos três vezes na semana.

P: Você tem ligação com algum shampoo específico, ou não?

B: Eu gosto muito dos shampoos da Pantene, ou então AlfaParf.

P: Bom, você citou aí duas marcas, Pantene e AlfaParf. Porque você escolheu essas duas marcas?

B: Acquaflora também...O Pantene porque eu me identifico com a marca, apesar de não ser Gisele Bundchen (risos) e por ser um produto barato. Já o Acquaflora e o AlfaParf eles são produtos para...são comercializados em salões, são bem mais caros...geralmente coisa que eu encontro shampoo e condicionado da Pantene eu encontro por vinte reais os dois no combo, o separado das outras marcas é trinta reais. Então, quando eu posso gastar mais e quando eu acho que o meu cabelo precisa de mais cuidado, aí eu compro os que são mais profissionais. Agora quando, realmente não dá e tal, aí eu compro Pantene, dos mais populares.

P: Entendi. Quando você disse que se identifica com a marca Pantene, o que isso significa para você?

B: Significa que eu gosto do produto, que eu acho que faz bem pro meu cabelo e, apesar de ser uma marca que é mais popular, tipo Seda e Niely, ainda assim é uma marca meio premium dentro do mercado popular...eu acho, é o que eu vejo como consumidora, é esse olhar que eu tenho. 
P: Então, você vai na farmácia, na hora de escolher um shampoo...você vai direto no Pantene?

B: Sim, a minha primeira opção na farmácia é o Pantene. Quando eu não acho Pantene eu vou por preço e por qualidade.

P: Bom, agora as perguntas são sobre emoção, então eu quero que você me diga o que é isso para você. A primeira pergunta é o que faria você ter medo de comprar um shampoo?

B: Medo de comprar um shampoo...saber que o cabelo de alguém caiu por causa desse shampoo, não quero ficar careca (risos), e...eu tenho uma amiga que é vegana, então ela parou de usar uns cosméticos por causa de testes em animais e, eu abraço bastante a causa e também não gostaria de usar um produto que testa em animais. Mas também não vou ficar procurando tudo porque é aquela coisa, o que os olhos não veem, o coração não sente. Então, apesar de ser meio estupido, mas eu procuro não saber de certas coisas para continuar usando. Mas acho que isso mesmo, o que eu não usaria mesmo era se eu soubesse que testa em animais e se conheço alguém que o cabelo caiu, ou que ficou faltando um tufo, alguma coisa assim.

P: E o que faria você ter inveja do cabelo de uma pessoa?

B: É...se o cabelo da pessoa fosse maravilhoso...assim, nossa eu usei esse produto e ele ficou sedoso, brilhante, macio, cresceu...até mexeu na cor um pouco, talvez clarear, porque eu gosto do meu cabelo um pouco mais claro...então eu gosto de produtos que tenham camomila ou coisas mais naturais, porque eu não quero usar mais químicas por conta de tintura...então eu me interessaria por um produto que talvez usasse camomila ou trouxesse os benefícios de brilho, maciez, que crescesse os fios..enfim.

P: E o que faria você sentir felicidade por um shampoo?

B: Felicidade...é, eu acho que seria ele ter isso tudo que eu te falei antes...não ter teste em animais, ser um produto acessível, né? Porque hoje em dia, com a crise, não dá para ficar pagando o que eu tinha te falado, de trinta e pouco reais em um shampoo Acquaflora ou Alfaparf...então, ele sendo um produto barato mas que ao mesmo tempo respeite os animais e que também não ouça nenhum 
caso de ninguém que perdeu cabelo usando o produto...além de também trazer a maciez, o brilho, lavar também, porque né? Acho que o principal do shampoo é lavar o cabelo e não deixar oleoso...e crescer..enfim, hidratado também.

P: Tá bom, é isso. Obrigado! 


\section{Anexo 9 - Briefings}

\section{BRIEFING PARA CRIACÃO DAS PECAS DE SHAMPOO}

1) IDENTIFICAÇÃO

- $\quad$ Cliente: Paulo Andrade

- Produto: Peças publicitárias geradoras de emoção

- Data:

- Job no 1: Emoções na comunicação de produtos.

Objetivo:

Esse documento tem como objetivo dar suporte à criação de publicidade, com a finalidade de evocar sentimentos nas pessoas que observarem as imagens em uma pesquisa que analisará o efeito do design emocional na comunicação de produtos.

Deverão ser criadas peças publicitárias que DESPERTEM emoções relacionadas a compra de shampoo. Devem ser trabalhadas, em peças diferentes, as seguintes emoções: medo, felicidade e inveja.

Job: Emoções na comunicação de produtos.

Obs.: todas as peças devem conter imagens masculinas e femininas.

- Medo

Em pesquisa prévia foram observadas as seguintes palavras como fator gerador dessa emoção: Cabelo estragado, seco e caspa. 
Essa peça deve apresentar uma mulher com cabelos secos e danificados; um homem com o cabelo cheio de caspa. A seguinte frase deve estar na imagem: Sem o nosso shampoo, o seu cabelo fica assim.

- Felicidade

A palavra chave de acordo com a pesquisa é: Brilho

Essa imagem deve conter uma mulher e um homem com seus cabelos bonitos, sedosos e macios. A frase "O nosso shampoo é a fórmula mágica para seus cabelos"

- Inveja

Aqui a palavra chave também será Brilho.

Um homem e uma mulher, de costas, com cabelos brilhosos e perfeitos sentados em um escritório luxuoso. A frase "Parte do seu sucesso reflete no brilho dos seus cabelos."

Obs.: ESSA IMAGEM DEVE SER QUASE UMA OSTENTACCÃO, MAS COM O FOCO NOS CABELOS.

\section{BRIEFING PARA CRIACÃ̃ DE PUBLICIDADE PARA UNIVERSIDADES}

\section{1) IDENTIFICAÇÃO}

- $\quad$ Cliente: Paulo Andrade

- Produto: Peças publicitárias geradoras de emoção

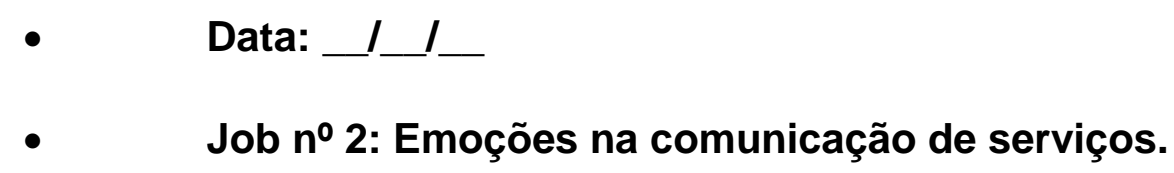

Job: Emoções na comunicação de serviços.

- Medo 
Em pesquisa prévia foram observadas as seguintes expressões como fator gerador dessa emoção: escolher curso/universidade errada

. A peça apresentará um cesto de lixo, contendo um diploma. Deve conter a frase: "Você escolheu certo, não é? Escolha a gente, para depois não reclamar."

- Felicidade

As palavras chaves, de acordo com a pesquisa são: pertencer ao espaco, sentir-se bem no local e poder trocar experiências.

Essa imagem deve conter o pilotis da PUC-Rio, ou qualquer imagem que valorize o campus, com alunos felizes e enturmados. A seguinte frase deve estar na peça: "A Universidade é um local de integração e trocas."

- Inveja

Aqui as palavras chaves são: excelência da universidade, oportunidades oferecidas por ela.

Essa peça deverá conter o ranking das melhores universidades do Brasil com a seguinte frase: "A universidade do seu concorrente está nessa lista?" 


\section{Anexo 10 - Questionário Quantitativo - Universidade}

Olá! Essa pesquisa faz parte do trabalho de conclusão do curso de Administração da PUC-Rio e tem como objetivo avaliar algumas propagandas de universidade. O importante é saber a sua opinião, não há resposta certa ou errada.

O registro é anônimo e você não levará mais que 6 minutos respondendo às questões.

Muito obrigado, desde já!

Q1 Você frequenta atualmente, ou está escolhendo uma universidade?

O $\operatorname{Sim}(1)$

O Não (2)

Condição: Não Está selecionado. Pular para: Fim da pesquisa.

Q2 Classifique as afirmativas a seguir, considerando a importância dos atributos apresentados na hora de escolher uma universidade. 


\begin{tabular}{|c|c|c|c|c|c|}
\hline & $\begin{array}{c}\text { Discordo } \\
\text { completamen } \\
\text { te (1) }\end{array}$ & $\begin{array}{l}\text { Discordo } \\
\text { parcialmen } \\
\text { te (2) }\end{array}$ & $\begin{array}{l}\text { Indiferent } \\
\text { e (3) }\end{array}$ & $\begin{array}{l}\text { Concordo } \\
\text { parcialmen } \\
\text { te }(4)\end{array}$ & $\begin{array}{c}\text { Concordo } \\
\text { completamen } \\
\text { te (5) }\end{array}$ \\
\hline $\begin{array}{l}\text { O CUSTO da } \\
\text { universidade } \\
\text { influencia a minha } \\
\text { escolha. (1) }\end{array}$ & $\mathrm{O}$ & $\mathrm{O}$ & $\mathrm{O}$ & $\mathrm{O}$ & O \\
\hline $\begin{array}{l}\text { O } \\
\text { RECONHECIMEN }\end{array}$ & & & & & \\
\hline $\begin{array}{l}\text { TO da universidade } \\
\text { influencia a minha } \\
\text { escolha. (2) }\end{array}$ & $\mathrm{O}$ & $\mathrm{O}$ & O & $\mathrm{O}$ & $\mathrm{O}$ \\
\hline A QUALIDADE DE & & & & & \\
\hline $\begin{array}{l}\text { ENSINO da } \\
\text { universidade } \\
\text { influencia a minha } \\
\text { escolha. (3) }\end{array}$ & $\mathrm{O}$ & O & $\mathrm{O}$ & O & $\mathrm{O}$ \\
\hline $\begin{array}{l}\text { As INSTALAÇÕES } \\
\text { da universidade } \\
\text { influenciam a } \\
\text { minha escolha. (4) }\end{array}$ & $\mathrm{O}$ & $\mathrm{O}$ & O & $\mathrm{O}$ & $\mathrm{O}$ \\
\hline $\begin{array}{l}\text { A INDICAÇÃO de } \\
\text { alguém influencia a } \\
\text { minha escolha de } \\
\text { universidade. (5) }\end{array}$ & $\mathrm{O}$ & O & O & $\mathrm{O}$ & $\mathrm{O}$ \\
\hline $\begin{array}{l}\text { O PROCESSO DE } \\
\text { ENTRADA (provas }\end{array}$ & & & & & \\
\hline $\begin{array}{l}\text { e/ou entrevistas) } \\
\text { influencia a minha } \\
\text { escolha. (6) }\end{array}$ & $\mathrm{O}$ & $\mathrm{O}$ & $\mathrm{O}$ & $\mathrm{O}$ & O \\
\hline $\begin{array}{l}\text { Uma } \\
\text { PROPAGANDA da } \\
\text { universidade } \\
\text { influencia a minha } \\
\text { escolha. (7) }\end{array}$ & O & $\mathrm{O}$ & $\mathrm{O}$ & $\mathrm{O}$ & O \\
\hline
\end{tabular}


Agora você vai ver peças de propaganda de universidade e gostaria que você respondesse algumas questões a respeito de cada uma delas.

Classifique a afirmação abaixo frente à PROPAGANDA DE UNIVERSIDADE apresentada. 
Q3 Essa propaganda me faz ter vontade de cursar essa universidade.

O Discordo completamente (1)

O Discordo parcialmente (2)

O Indiferente (3)

O Concordo parcialmente (4)

O Concordo completamente (5)

Q4 Que sensações você teve ao observar essa peça? (você pode marcar mais de uma opção, se preferir)

Medo (1)

Gelicidade (2)

- Alegria (3)

- Angústia (4)

- Preocupação (5)

- Aversão (6)

口 Prazer (7)

प Satisfação (8)

口 Contente (9)

口 Inveja (10)

口 Ciúme (11)

$\square$ Desejo (12)

․ Cobiça (13)

๑ Ambição (14)

Observação: As perguntas que seguem são apenas para efeitos de classificação das respostas.

Q5 Qual a sua idade?

Q6 Nível de escolaridade.

O Ensino Fundamental Incompleto (1)

O Ensino Fundamental Completo (2) 
O Ensino Médio Incompleto (3)

O Ensino Médio Completo (4)

O Curso Técnico Incompleto (5)

O Curso Técnico Completo (6)

O Graduação Incompleta (7)

O Graduação Completa (8)

O Mestrado Incompleto (9)

O Mestrado Completo (10)

O Doutorado Incompleto (11)

O Doutorado Completo (12)

Q7 Qual a sua renda familiar mensal? (A soma da renda de todos que moram com você)

O Até $\mathrm{R} \$ 1.874,00(1)$

O Entre $R \$ 1.874,01$ e $R \$ 3.748,00$ (2)

O Entre $R \$ 3.748,01$ e $R \$ 9.370,00$ (3)

O Entre $R \$ 9.370,01$ e $R \$ 18.740,00$ (4)

O $R \$ 18.740,01$ ou mais. (5)

Q8 Sexo.

O Masculino (1)

O Feminino (2)

O Outro (3) 


\section{Anexo 11 - Questionário Quantitativo - Shampoo}

Olá! Essa pesquisa faz parte do trabalho de conclusão do curso de Administração da PUC-Rio e tem como objetivo avaliar algumas propagandas de shampoo.

O importante é saber a sua opinião, não há resposta certa ou errada.

O registro é anônimo e você não levará mais que 6 minutos respondendo às questões.

Muito obrigado, desde já!

Q1 Você usa shampoo?

O $\operatorname{Sim}(1)$

O Não (2)

Condição: Não Está selecionado. Pular para: Fim da pesquisa.

Q2 Você que escolhe o shampoo que usa? 
O $\operatorname{Sim}(1)$

O Não. Quem escolhe? (2)

Q3 Classifique as afirmativas a seguir, considerando a importância dos atributos apresentados na hora de escolher um shampoo. 


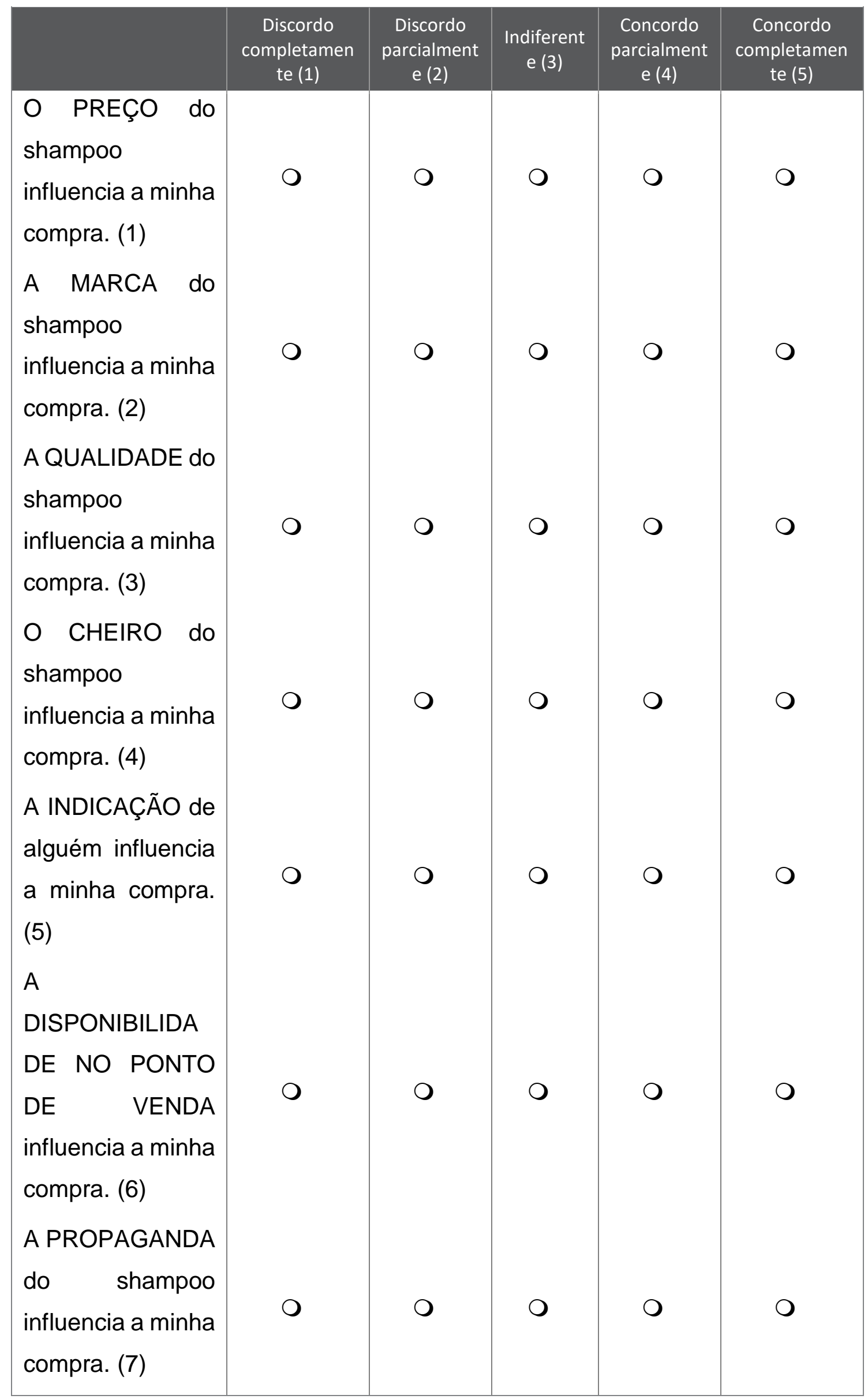


Agora você vai ver peças de propaganda de shampoo e gostaria que você respondesse algumas questões a respeito de cada uma delas.

Classifique a afirmação abaixo frente à PROPAGANDA DE SHAMPOO apresentada.

Q4 Essa propaganda me faz ter vontade de comprar o shampoo apresentado.

O Discordo completamente (1)

O Discordo parcialmente (2)

O Indiferente (3)

O Concordo parcialmente (4)

O Concordo completamente (5)

Q5 Que sensações você teve ao observar essa peça? (você pode marcar mais de uma opção, se preferir)

Medo (1)

- Felicidade (2)

a Alegria (3)

- Angústia (4)

- Preocupação (5)

口 Aversão (6)

- Prazer (7)

- Satisfação (8)

- Contente (9)

口 Inveja (10)

- Ciúme (11)

- Desejo (12)

- Cobiça (13)

- Ambição (14)

Observação: As perguntas que seguem são apenas para efeitos de classificação das respostas. 
Q6 Qual a sua idade?

Q7 Nível de escolaridade.

O Ensino Fundamental Incompleto (1)

O Ensino Fundamental Completo (2)

O Ensino Médio Incompleto (3)

O Ensino Médio Completo (4)

O Curso Técnico Incompleto (5)

O Curso Técnico Completo (6)

O Graduação Incompleta (7)

O Graduação Completa (8)

O Mestrado Incompleto (9)

O Mestrado Completo (10)

O Doutorado Incompleto (11)

O Doutorado Completo (12)

Q8 Qual a sua renda familiar mensal? (A soma da renda de todos que moram com você)

O Até $\mathrm{R} \$ 1.874,00(1)$

O Entre $R \$ 1.874,01$ e $R \$ 3.748,00$ (2)

O Entre $R \$ 3.748,01$ e $R \$ 9.370,00$ (3)

O Entre $R \$ 9.370,01$ e $R \$ 18.740,00$ (4)

O $\mathrm{R} \$ 18.740,01$ ou mais. (5)

Q9 Sexo.

O Masculino (1)

O Feminino (2)

O Outro (3) 


\section{Anexo 12 - Propagandas Utilizadas na Pesquisa}

\section{Quantitativa}

Propagandas de Apoio:

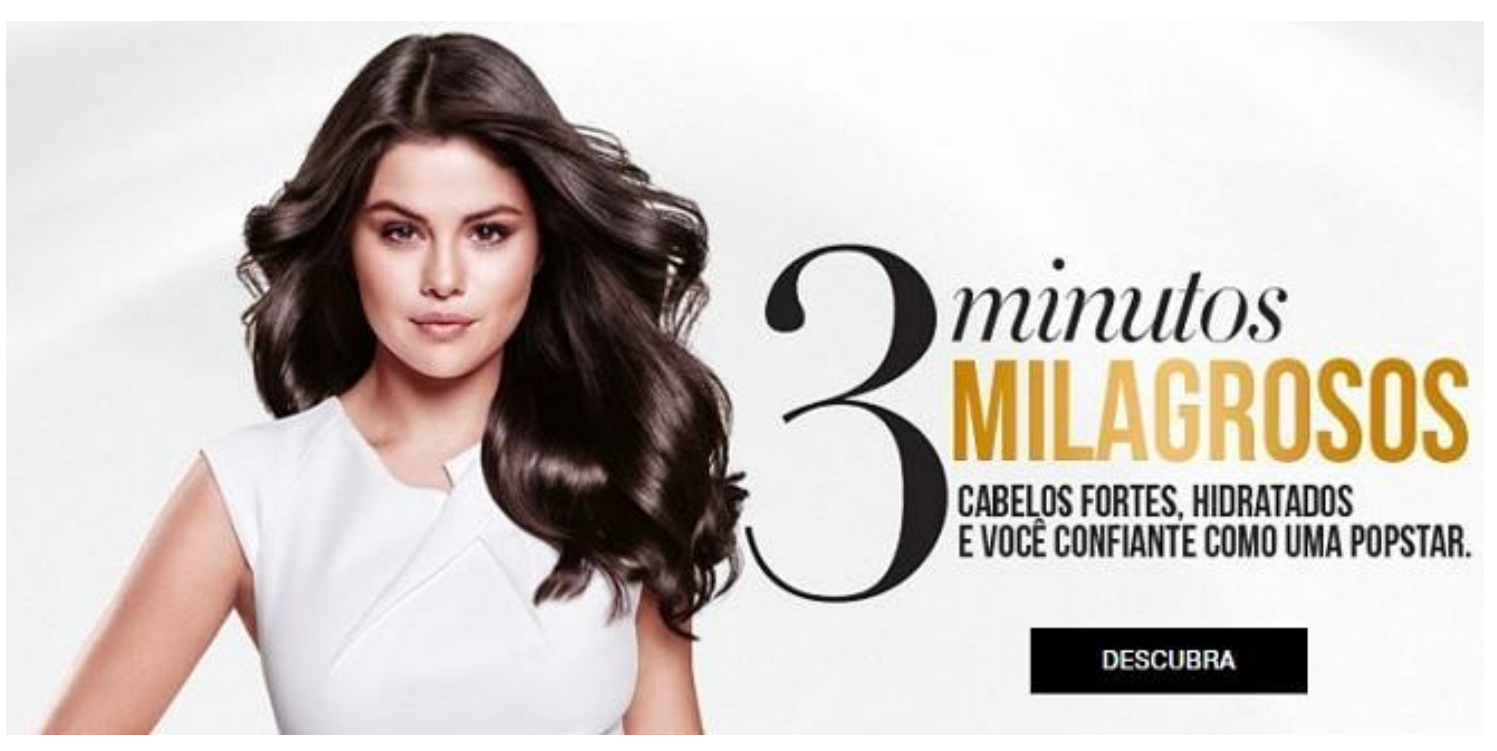

$$
\begin{aligned}
& \text { UM FUTURO } \\
& \text { SOLIDO COMECCA } \\
& \text { COM UM ENSINO } \\
& \text { DE QUALIDADE. }
\end{aligned}
$$


Propagandas de Shampoo:

Buscando despertar felicidade:

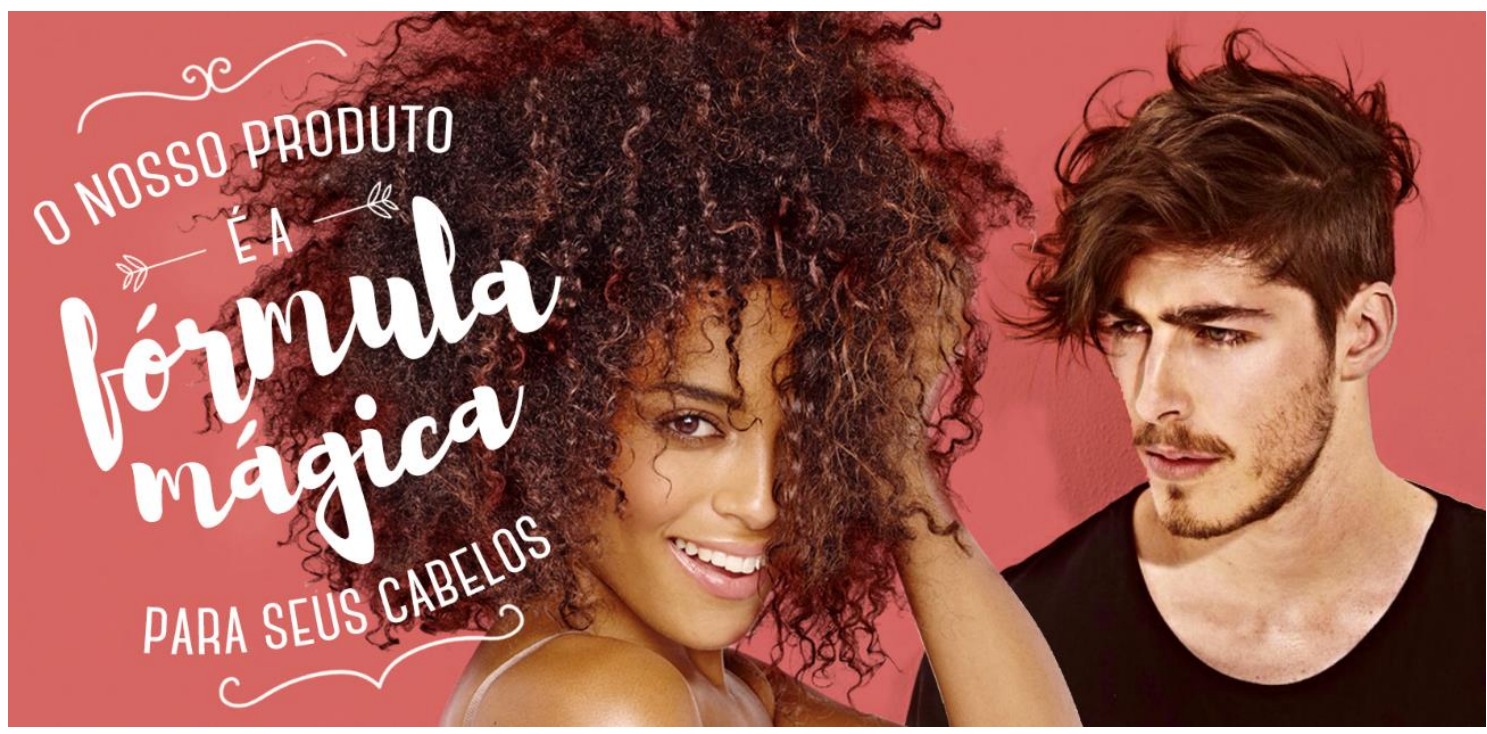

Buscando despertar inveja:

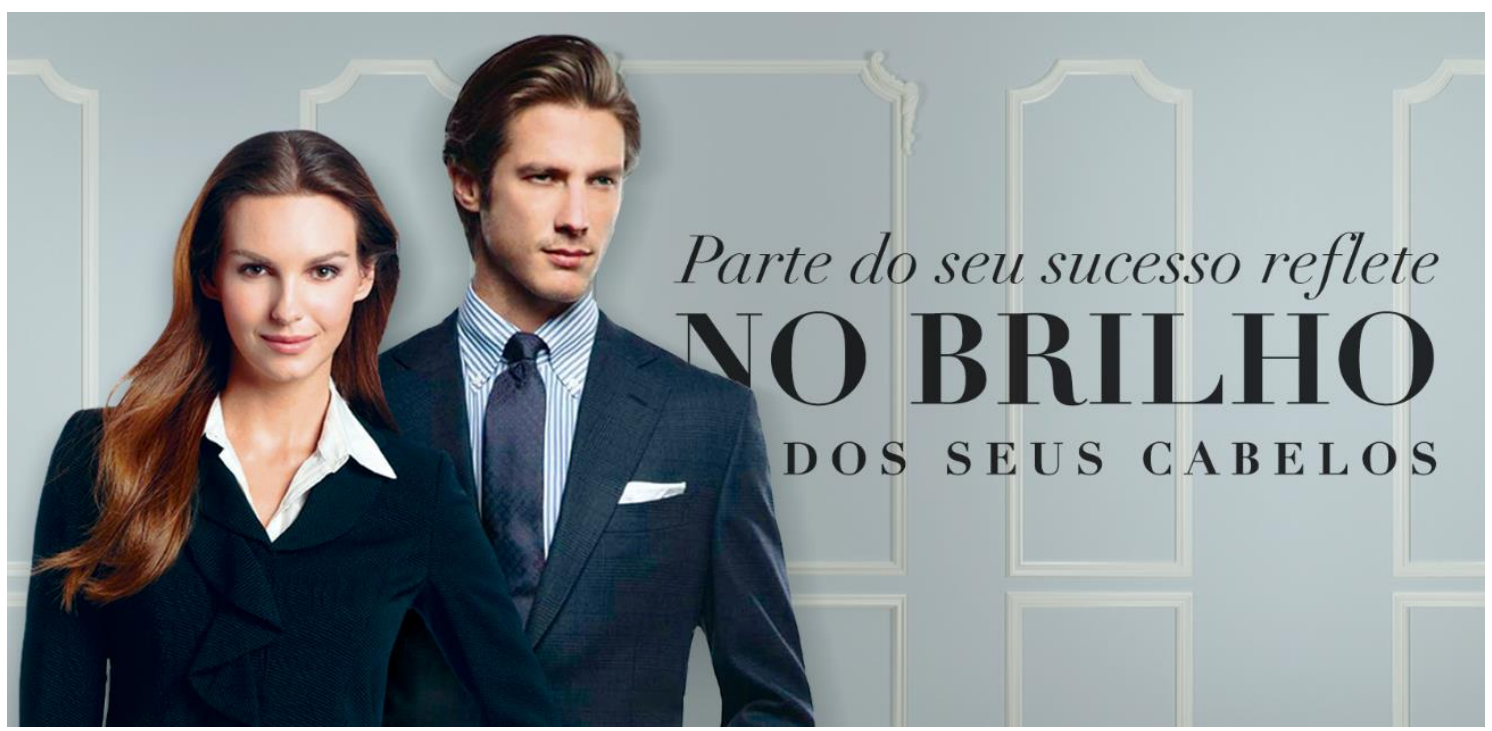

Buscando despertar medo: 
SEM O NOSSO SHAMPOO O SEU CABELO FICA ASSIM.

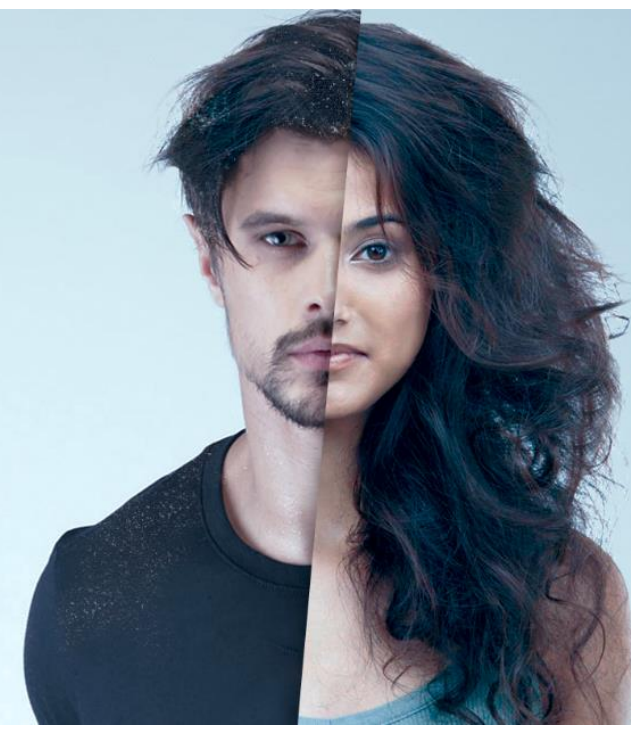

Propagandas de Universidade:

Buscando despertar felicidade:

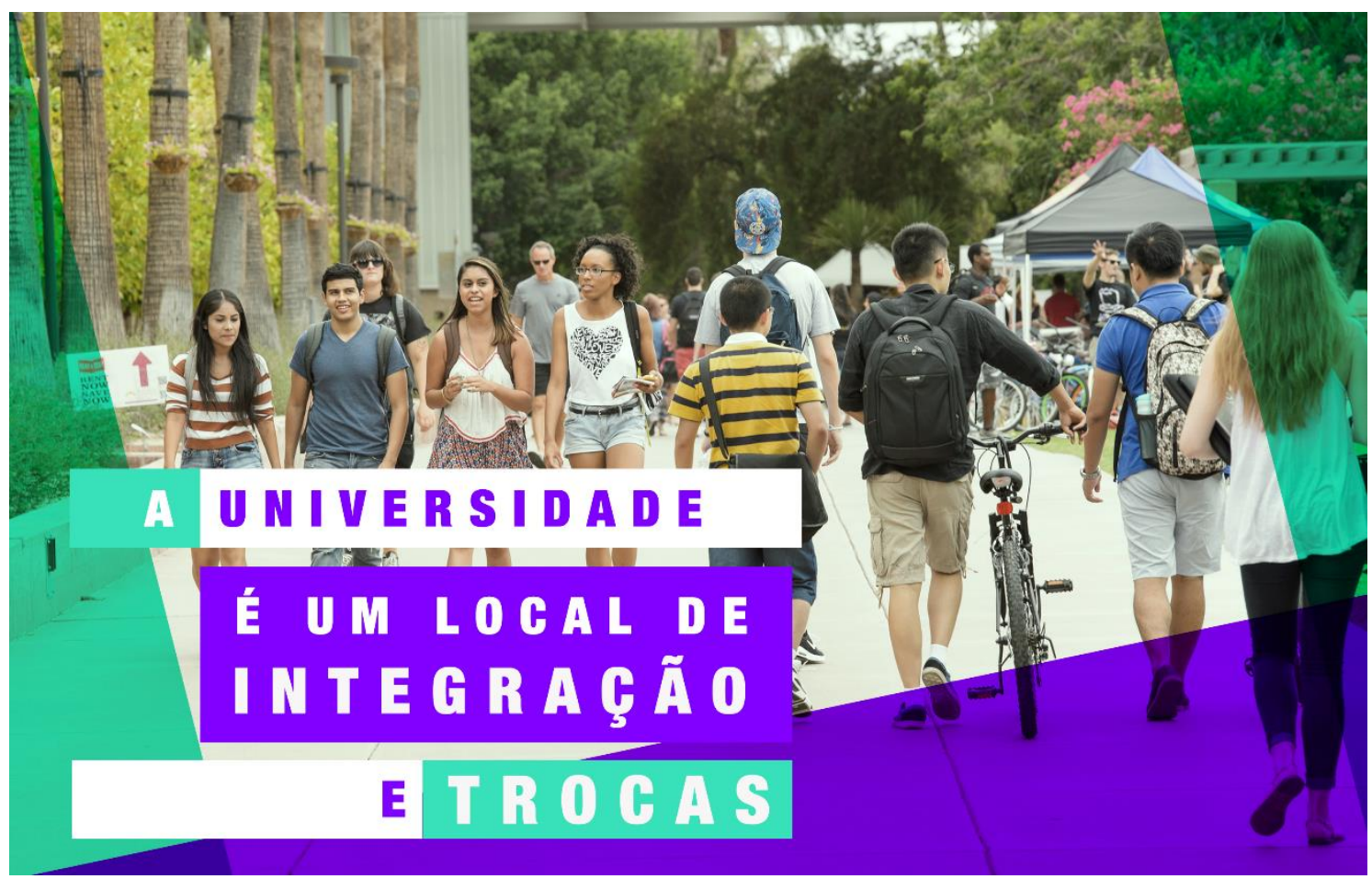

Buscando despertar inveja: 


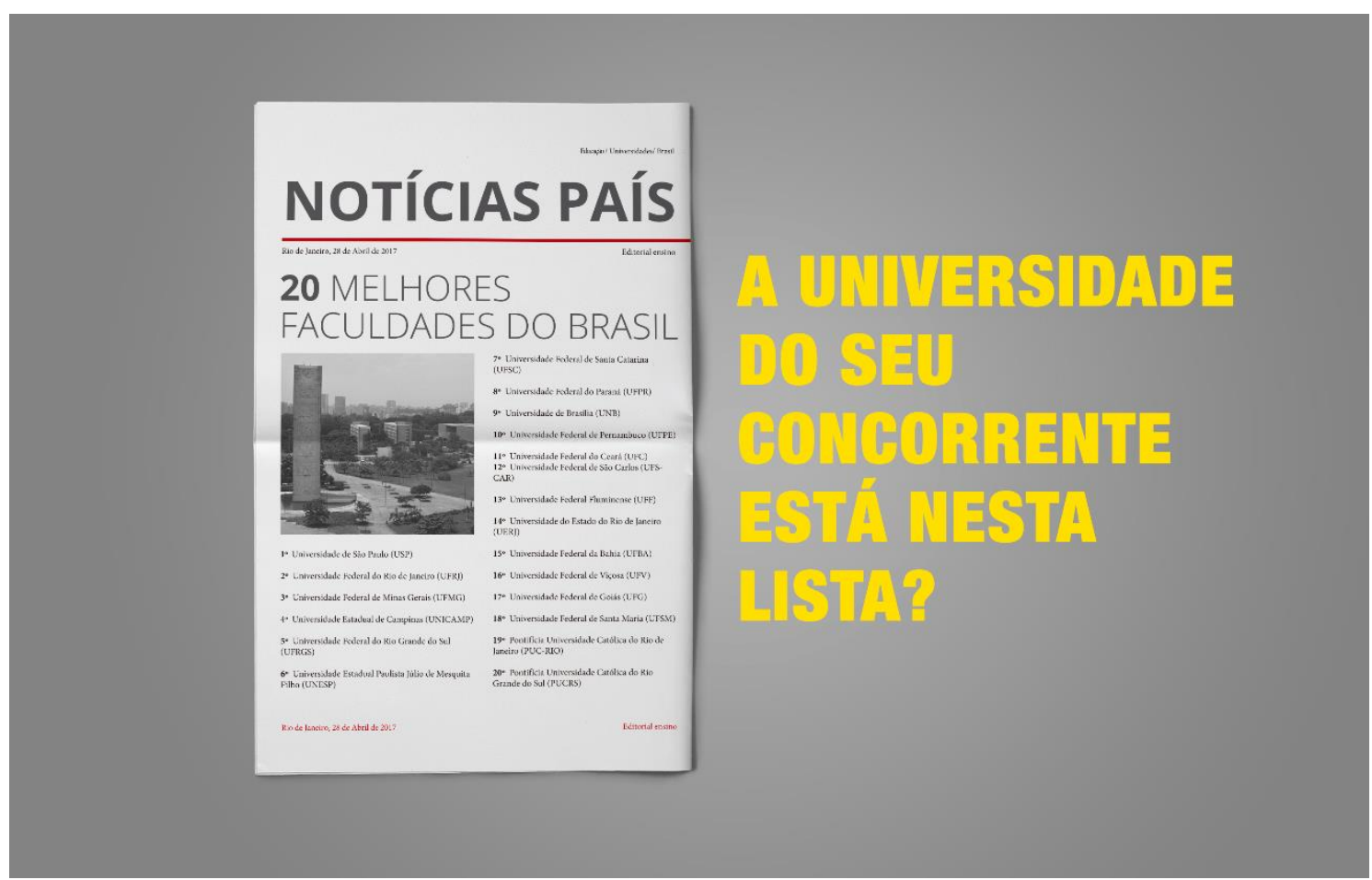

Buscando despertar medo:

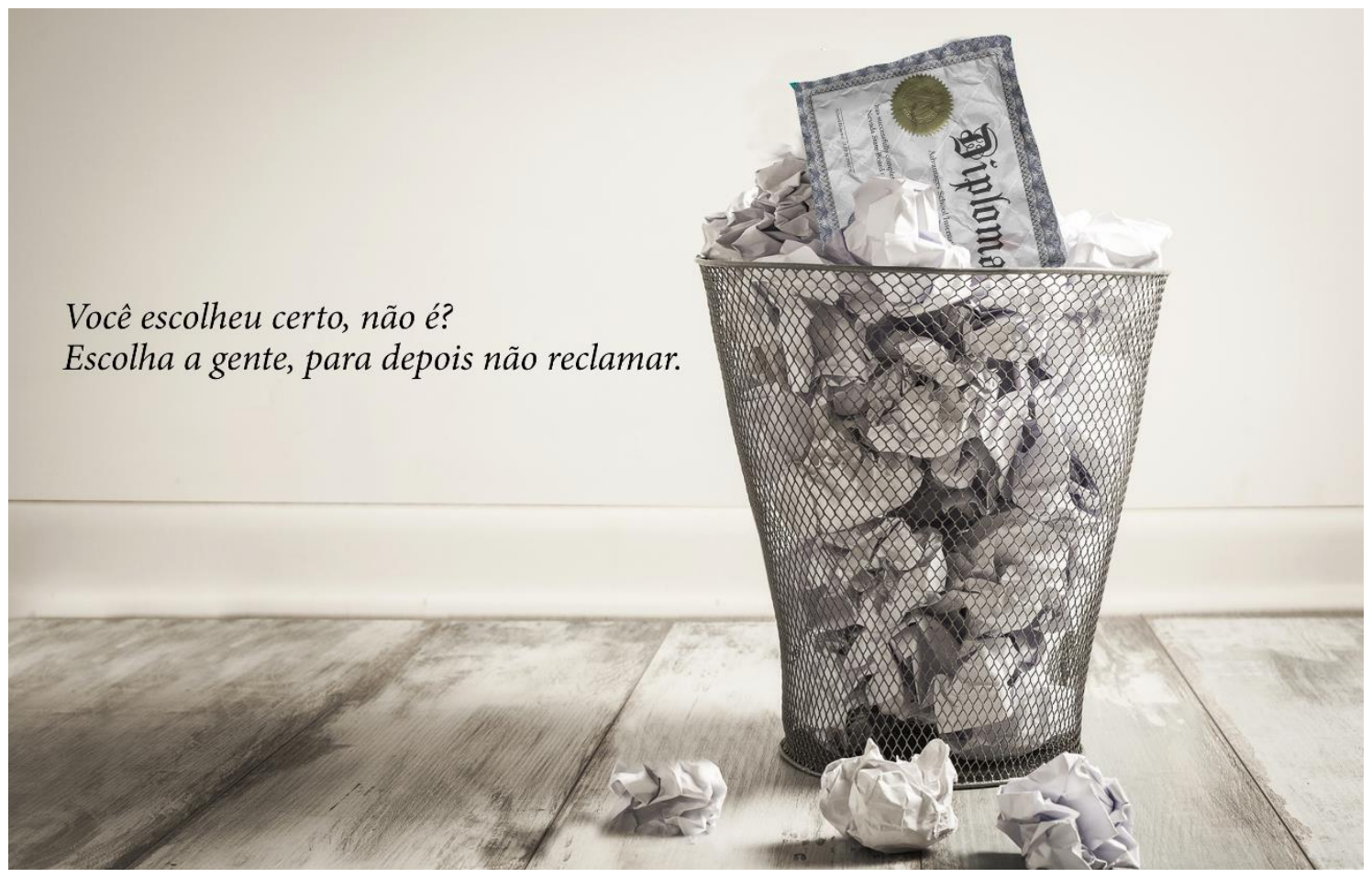

